\title{
Moving the Customer Experience Field Forward: Introducing the Touchpoints, Context, Qualities (TCQ) Nomenclature
}

\author{
Arne De Keyser, Katrien Verleye, Katherine N. Lemon, Timothy L. Keiningham, and Phil
}

Klaus

\section{Forthcoming in the Journal of Service Research}

May 1, 2020

\begin{abstract}
Arne DE KEYSER (contact author) is Assistant Professor of Marketing at the Department of Marketing, EDHEC Business School, France. Contact information: 24 Avenue Gustave Delory, CS 50411, 59057 Roubaix Cedex 1, France, Tel. (+32) 494263493, Email: arne.dekeyser@edhec.edu
\end{abstract}

Katrien VERLEYE is Assistant Professor of Service Innovation at the Center for Service Intelligence, Department of Marketing, Innovation and Organisation, Ghent University, Belgium. Contact information: Tweekerkenstraat 2, 9000 Ghent, Tel. (+32) 9-264-3494, Email: katrien.verleye@ugent.be

Katherine N. LEMON is Accenture Professor of Marketing at the Department of Marketing, Carroll School of Management, Boston College. Contact information: Fulton Hall 510, 140 Commonwealth Avenue, Chestnut Hill, MA 02467, United States, Tel. (1) 617-552-1647, Email: kay.lemon@bc.edu

Timothy L. KEININGHAM is the J. Donald Kennedy Endowed Chair in E-Commerce and Professor of Marketing at the Department of Marketing, Peter J. Tobin College of Business, St. John's University. Contact information: 8000 Utopia Parkway, Queens, NY 11439, United States, Tel. (1) 718-990-6800, Email: keiningt@stjohns.edu

Philipp 'Phil' KLAUS is Associate Professor of Customer Experience Strategy and Management at the Department of Marketing, INSEEC U Research Center, International University of Monaco. Contact information: Le Stella, 14 Rue Hubert Clerissi, 98000 Monaco, Tel. (+377) 97-98-69-86, Email: pklaus@monaco.edu

Keywords: customer experience, customer experience management, marketing strategy, touchpoints, experience qualities, experience stages, experience context, customer journey

Acknowledgements: The authors would like to acknowledge support of the Marketing Science Institute (MSI). They also wish to thank seminar participants at CTF (Karlstad University) for their feedback, as well as Bart Larivière (KU Leuven) and the members of the Center for Service Intelligence (Ghent University). 


\title{
Moving the Customer Experience Field Forward: Introducing the Touchpoints, Context, Qualities (TCQ) Nomenclature
}

\begin{abstract}
In response to initial voices that put the customer experience (management) $(\mathrm{CX}(\mathrm{M})$ hereafter) movement into question, this paper aims to introduce a formal nomenclature to push the $\mathrm{CX}(\mathrm{M})$ field toward a more mature state. First, drawing from an inductive analysis of $143 \mathrm{CX}(\mathrm{M})$ papers, the authors identify twelve basic CX components which aggregate into three overarching building blocks - touchpoints ( $\mathrm{T}$ - i.e., points of interaction between the customer and brand/firm), context (C - i.e., situationally available resources internal and/or external to the customer), and qualities ( $\mathrm{Q}$ - i.e., attributes that reflect the nature of customer responses and reactions to interactions with the brand/firm). The TCQ nomenclature offers a language to make $\mathrm{CX}$ actionable, moving beyond the breadth of the current definition and frameworks by disentangling CX into small bite-sized chunks (i.e., the CX components) that any academic and practitioner, regardless of their discipline, may understand and use to discuss and manage CX. Second, using the TCQ nomenclature, the authors assess the current state of the CX(M) literature and identify mature (e.g., firm-controlled touchpoints and cognitive and emotional qualities associated with CX) and underdeveloped (e.g., non-firm controlled touchpoints and the market and environmental context in which CX emerges) areas ripe for future research. In addition, they also provide a set of recommendations to strengthen the methodological rigor of the field. Third, the TCQ nomenclature may support managers in auditing their current CXM practices and/or serve as a basis for CX design and innovation.
\end{abstract}

Keywords: customer experience, customer experience management, marketing strategy, touchpoints, experience qualities, experience stages, experience context, customer journey 
In little time, $\mathrm{CX}$ has become one of the dominant marketing concepts for both practitioners and academics. 93 percent of business leaders today say that delivering a relevant and reliable CX is critical to overall business performance (HBR Analytic Services 2017). Not surprisingly, academic research on CX and its management (CXM) is flourishing. Well-cited work appeared in popular managerial outlets (e.g., Harvard Business Review: Meyer and Schwager 2007; Rawson, Duncan, and Jones 2013) and high-ranked academic journals (e.g., Journal of Marketing: Brakus, Schmitt, and Zarantonello 2009, Lemon and Verhoef 2016; Journal of the Academy of Marketing Science: Homburg, Jozíc, and Kuehnl 2017, Lemke, Clark, and Wilson 2011; Journal of Retailing: Grewal, Levy, and Kumar 2009, Verhoef et al. 2009; Journal of Service Research: McColl-Kennedy et al. 2019). Equally, CX(M) has been featured a top priority in five consecutive publications of the Marketing Science Institute research priorities, covering the 2010-2020 period (MSI 2010, 2012, 2014, 2016, 2018).

Despite the widespread conviction of CX(M)'s importance and the various contributions delivered by academic and practitioner work, we observe a $\mathrm{CX}(\mathrm{M})$ field that is struggling to reach a level of maturity that can and should be expected (Forrester Research 2019; Lemon and Verhoef 2016). Some reports claim that only 1 in 3 CXM initiatives are successful (Thompson 2018), while others contend that the majority of brands/firms that poured significant resources into their CXM programs fail to deliver and see weak returns (Morgan 2018). Initial voices putting the CX(M) movement into question are slowly growing, as exemplified by popular press quotes like 'It's time for CX to put up, or shut up' (Thompson 2018) and 'Customer experience will be a fad without a better business case' (Latib 2018). Hence, action is needed if the CX(M) field wants to be more than just the "flavor of the month" in the corporate world.

To date, $\mathrm{CX}(\mathrm{M})$ researchers have delineated CX from evaluative concepts such as satisfaction and service quality and motivational concepts like engagement (e.g., Lemon and 
Verhoef 2016). Building upon the most prevalent definitions across different research traditions, Becker and Jaakkola (2020) defined CX as non-deliberate, spontaneous responses and reactions to offering-related stimuli embedded within a specific context. The broadness of this $\mathrm{CX}$ definition (i.e., CX is everything), however, does not provide much help to scope and develop a manageable CX program (Maklan, Antonetti and Whitty 2017; Keiningham et al. 2020). Becker and Jaakkola (2020) confirm that an atomistic understanding of the content of CX is needed to delineate what its monitoring, design, and management entails and call for novel research filling this void. Quotes from business press and popular blogs echo similar concerns: 'CEOs are giving lip service to $C X$, without really understanding what it means' (Thompson 2018).

To add granularity to the very broad CX definition while also ensuring its actionability, this research aims to disentangle small bite-sized chunks - here, labeled as CX components - that any academic and practitioner regardless of their discipline may understand and use to discuss and manage CX. By devising labels for these CX components, this research establishes a much-needed formal CX nomenclature (Klaus 2019). Every mature field necessarily relies on a nomenclature to reduce misunderstandings and support effective research, measurement, design and management practices (MacInnis 2011; Mele, Pels, and Storbacka 2015). Specifically, following an inductive analysis of 143 CX(M) papers, we identify twelve CX components that aggregate into three overarching building blocks: (1) Touchpoints (i.e., points of interaction between the customer and brand/firm), (2) Context (i.e., situationally available resources internal and/or external to the customer), and (3) Qualities (i.e., attributes that reflect the nature of customer responses to interactions with the brand/firm). These building blocks and their components form the basis of the TCQ nomenclature, capturing the essence of $\mathrm{CX}$ as a concept in simple and precise terms. Additionally, we complement the development of the TCQ nomenclature with an analysis of 
the meta-data (i.e., research method and research context) distilled from the analyzed CX(M) literature.

The TCQ nomenclature will allow us to contribute to $\mathrm{CX}(\mathrm{M})$ research and practice in three meaningful ways. First, the TCQ nomenclature helps reduce misunderstanding and conceptual ambiguity among $\mathrm{CX}(\mathrm{M})$ researchers and practitioners through identifying and listing all its underlying CX components (as called for by Keiningham et al. 2020). Second, the TCQ nomenclature allows us to assess the current state of academic CX(M) work and identify existing gaps in our knowledge. In combination with the meta-data analysis, we make recommendations to broaden the methodological rigor and inclusiveness of the CX(M) field. Third, the TCQ nomenclature makes CX actionable and enables business practice in their CXM ambitions. Specifically, we discuss how the TCQ nomenclature may be used to audit CXM programs and identify "quick wins" to strengthen current CXM and can also serve as a basis for CX design and innovation practices, enabling fast identification of opportunities for differentiation and excellence. This is in line with calls by Lemon and Verhoef (2016) and Becker and Jaakkola (2020) for CX(M) research that may assist researchers and managers to define the content of intended CXs - something a nomenclature is well suited for. It is our hope that, armed with this new approach, brands/firms will (finally) be able to make a clear business case for CXM.

The paper is organized as follows. First, we identify and describe the overarching CX building blocks and their components by means of an inductive analysis of existing CX definitions and a fine-grained analysis of $143 \mathrm{CX}(\mathrm{M})$ papers. The analysis lays the foundation for the TCQ nomenclature and develops each building block conceptually. Second, we consider how strongly CX(M) literature has focused on each of the building blocks and their components, identifying critical research gaps and opportunities to push the field forward. Third, we discuss methodological challenges that need to be overcome in line 
with the TCQ nomenclature. Finally, we consider how the TCQ nomenclature may be used by business practice as a language for two particular applications in which the value of the building blocks and their components becomes evident: (1) steering CX audits and (2) improving CX design/innovation efforts.

\section{METHOD FOR A FINE-GRAINED ANALYSIS OF CX(M) LITERATURE}

Over the past 10 years, CX(M) literature has grown at a tremendous pace (Mahr et al. 2019). Earlier review studies -summarized in Table 1 - have helped to identify different CX(M) research streams and/or theoretical underpinnings (e.g., Helkkula 2011, Lipkin 2016, Mahr et al. 2019). Additionally, these studies position and distinguish $\mathrm{CX}$ in relation to other constructs, with an emphasis on (1) evaluative concepts such as perceived service quality, satisfaction, and value-in-use and (2) motivational concepts such as customer engagement (e.g., Becker and Jaakkola 2020; De Keyser et al. 2015; Lemon and Verhoef 2016; Rose et al. 2011) as two strongly related fields of research. Specifically, this research has shown how $\mathrm{CX}$ is crucial to the evaluation of the experience object (i.e., value-in-use), thereby affecting engagement with the experience object (Chandler and Lusch 2015). Finally, some review studies focused on how CX evolves throughout the customer journey, thereby introducing a dynamic perspective on CX (e.g., Kranzbühler et al. 2018; Lemon and Verhoef 2016).

\section{INSERT TABLE 1 AROUND HERE}

Although the aforementioned review studies contribute to a holistic understanding of $\mathrm{CX}$, the present research adopts an atomistic perspective by introducing a nomenclature in which we specify the basic components from which CX is built up. Both Lemon and Verhoef (2016) and Becker and Jaakkola (2020) see this as a necessary complement to the existing review papers. To this end, we engaged in a systematic process to identify and select relevant $\mathrm{CX}(\mathrm{M})$ articles and subsequently analyzed and synthesized these articles. Additionally, the present research also complements previous review studies by analyzing the meta-data of 
$\mathrm{CX}(\mathrm{M})$ articles (here, research method and research context). Doing so, this research is an important step to assist and support researchers and practitioners to design, measure, and manage CX (practices) backed-up by a clear nomenclature that captures the building blocks and key components of CX (MacInnis 2010; Mele, Pels, and Storbacka 2015). In combining the CX nomenclature with insights derived from the meta-data analysis, we are able to put forth avenues for future research, provide methodological recommendations for empirical work and identify opportunities to strengthen the CX(M) space. Table 1 details the key differences between this study and earlier reviews of the $\mathrm{CX}(\mathrm{M})$ literature.

\section{Identifying and Selecting Relevant CX(M) Literature}

We sourced articles from Web of Science's Social Sciences Citation Index platform as it provides a comprehensive portfolio of business and management journals. To ensure the objectivity, transparency and replicability of our bibliographic search, we followed a fivestep procedure proposed by Kranzbühler et al. (2018). Figure 1 visualizes these steps.

\section{INSERT FIGURE 1 AROUND HERE}

First, we identified the most common keywords from the leading publications in the field (e.g., Verhoef et al. 2009; Lemon and Verhoef 2016) and previous literature reviews and used these as a basis for our search string. Specifically, we searched for articles containing the words "customer experience", “consumption experience", "service experience", “consumer experience”, “customer journey”, “consumer journey”, or “experiential marketing" in the title, abstract or author keywords. This resulted in 1,826 articles, covering the 1982 - January 2020 timeframe.

Second, to increase the relevance and quality of our results set, we limited our selection to peer-reviewed, academic journals in English. Abstracts of published items, books, books chapters, book reviews, discussion, commentary, editorial material, and proceeding papers were excluded. Also, the results were refined with respect to subject 
categories "Business" and "Management". Furthermore, we included only articles from journals in the Top 100 of the 2019 Journal Citation Report (JCR) for the Business and Management fields (Kranzbühler et al. 2018). All this refinement resulted in 680 articles.

Third, we performed a thorough screening of all remaining articles in terms of face validity, considering whether $\mathrm{CX}(\mathrm{M})$ was indeed the core topic of the study. This resulted in 156 remaining articles. Fourth, we reviewed the full text of the remaining set of articles, discarding another 54 articles as they did not provide a CX(M) definition and/or description. Fifth, this process also led to the identification and inclusion of 41 additional papers based on cross-references. Web Appendix A provides the full references of the 143 articles included in our analyses.

\section{Analyzing and Synthesizing Relevant CX(M) Literature}

The analysis of the selected articles involved - in line with the approach suggested by Moeller et al. (2013) - five steps: familiarizing with the articles, coding article content, categorizing codes, comparing codes/categorizations, and further analyzing. After importing all articles in NVivo, two members of the research team familiarized with the articles by reading through these articles in chronological order and selected all definitions and descriptions of CX. After in-vivo coding (Saldaña 2014) of all components of the CX definitions and descriptions (first-order codes), the two researchers independently grouped these CX components into categories and subsequently compared their second-order codes (see Web Appendix B for more details on coding agreement). All inconsistencies were resolved through discussions in which a third member of the research team was also involved. After grouping the second-order codes in more abstract third-order categories, three common and overarching CX building blocks emerged: (1) touchpoints, (2) context, and (3) experience qualities. Web Appendix B gives an overview of the first-order and second-order categories associated with these building blocks. Following further inquiry of the way in 
which $\mathrm{CX}(\mathrm{M})$ researchers link these three building blocks to one another, we contend that CX is formed through touchpoints $(T)$ which are embedded in a broader context $(C)$ and marked by a set of qualities $(Q)$ that, together, result in a value judgement by the customer. Additionally, we also explore the meta-data (i.e., research method and research context) associated with each of these components and building blocks.

Below, we first detail each of the components of the respective building blocks identified throughout the analyses and synthesis of the $\mathrm{CX}(\mathrm{M})$ literature, which provide the foundations of the TCQ nomenclature. Second, we consider future research opportunities building on the TCQ perspective and identified foci in the literature. Third, we zoom-in on the methodological challenges the CX(M) field is facing from a TCQ perspective. Finally, we consider the managerial opportunities and value of the TCQ nomenclature.

\section{MOVING TOWARDS THE TCQ NOMENCLATURE}

In this section, we aim to detail the TCQ nomenclature, which allows firms and scholars to discuss, assess and manage $\mathrm{CX}$ in a clear and concise manner. Figure 2 provides a visual summary of the TCQ nomenclature with its building blocks and components. For each of the building blocks in the TCQ nomenclature, we describe the identified components (see Web Appendices C, D and E for the presence of the components per paper in our sample) and refer to their coverage in $\mathrm{CX}(\mathrm{M})$ studies. Table 2 gives an overview of the coverage of the different components per building block in $\mathrm{CX}(\mathrm{M})$ studies.

ADD FIGURE 2 AROUND HERE

ADD TABLE 2 AROUND HERE

\section{Building Block 1: Touchpoints}

Touchpoints reflect the array of individual contacts between the brand/firm and customers across the customer journey that serve a purpose such as information gathering, payment, unpacking, and usage (Homburg, Jozíc, and Kuehnl 2017; Lemon and Verhoef 2016). These 
touchpoints are critical to experience formation as without any actual or imagined interaction taking place, there can be no CX (Hoffman and Novak 2018). Touchpoints vary in terms of control, nature, and the stage of the customer journey.

Touchpoint control reflects who is in charge of the contact points between customer and the brand/firm. Touchpoints may be controlled by the brand/firm or not. Firm-controlled touchpoints are those predominantly designed and controlled by the brand/firm (Verhoef et al. 2009). These typically include the store environment, corporate website, advertising, employees and so forth. Non-firm-controlled touchpoints are predominantly controlled by the customer, influencers, or other brands or firms (Kranzbühler, Kleijnen, and Verlegh 2019; Lemon and Verhoef 2016). As shown in Table 2, the CX(M) literature is dominantly focused on firm-controlled touchpoints (100\% of the papers in our sample), but we observe a growing recognition of non-firm-controlled touchpoints (46.85\%; e.g., Lemon and Verhoef 2016), with especially the role of other customers for CX(M) being recognized (e.g., Grove and Fisk 1997; Verhoef et al. 2009; Brocato, Voorhees and Baker 2012; Gao, Melero-Polo, and Sese 2020). More recently, there is also an increased interest into the role that other brands/firms play through the lens of service delivery networks (e.g., Tax, McCutcheon, and Wilkinson 2013) and branded outsourcing activities (e.g., Kranzbühler, Kleijnen, and Verlegh 2019).

Touchpoint nature reflects the way in which the brand/firm is represented in the touchpoint. A touchpoint can be human (e.g., frontline employee), digital (e.g., ATM, website), physical (e.g., store environment) or a combination thereof. Early research on touchpoint nature largely concentrates on human and physical touchpoints (e.g., Arnould and Price 1993; Hui and Bateson 1991; Schouten, McAlexander, and Koenig 2007) (human: 41.96\% - physical: 40.56\%). However, research looking into digital touchpoints (33.57\%) is rapidly catching up, with papers focusing on online CX(M) (e.g., Rose et al. 2012; Klaus 2013; Mclean, AlNabhani, and Wilson 2018; Bleier, Harmeling, and Palmatier 2019) and more recently the 
smart service experience (e.g., Hoffman and Novak 2018; Kabadayi et al. 2019).

Touchpoint stage reflects a specific phase in which touchpoints occur along the customer journey (Bolton et al. 2014; McColl-Kennedy et al. 2015; Verhoef et al. 2009; Kranzbühler et al. 2018). Three touchpoint stages are identified: a prepurchase, purchase, and post-purchase stage. The prepurchase stage comprises all moments related to a customer's interaction with a specific touchpoint before the purchase decision. It is typically referred to as the sequence of need recognition, information search, and evaluation in the consumer decision process (Puccinelli et al. 2009). The purchase stage relates to customer interactions with touchpoints during the purchase decision and act. This involves all moments related to consumer choice, ordering, paying, pick-up and delivery (Lemon and Verhoef 2016). The postpurchase stage encompasses touchpoints that relate to actual usage and consumption moments of the products or services, such as brand communities (e.g., Schouten, McAlexander, and Koenig 2007; Caru and Cova 2015) and product-return points (e.g., Lemon and Verhoef 2016). Overall, we observe a widespread recognition of all individual stages across CX(M) literature (pre-purchase: $36.36 \%$, purchase: $37.06 \%$, post-purchase: $39.86 \%$ ).

\section{Building Block 2: Context}

Driven by service-dominant logic and consumer culture theory scholars, the importance of context for $\mathrm{CX}(\mathrm{M})$ is widely acknowledged in the literature (see Web Appendix C for details). A customer can experience a touchpoint very differently at distinctive moments in time due to the context in which his or her interaction with the brand/firm is embedded (Thompson, Locander and Polio 1989). Broadly speaking, context refers to the conditional state that determines the resources a person can directly and indirectly draw on at some point in time (Bettencourt, Lusch, and Vargo 2014; Chandler and Vargo 2011) - driving the subjective nature of CX in that every CX is unique for every customer (Sandström et al. 2008). In line with Belk (1975), we consider context to comprise all factors that are particular to a certain 
time and/or place (i.e., situational - McColl-Kennedy et al. 2019) and typically transitory in nature. Although the exact nature of contextual influences is not always specified, $78.32 \%$ of the CX(M) studies recognizes the importance of context (see Web Appendix D). Overall, we discern factors related to the individual, social, market, and environmental context. We detail each of these contextual influences and their coverage below.

The individual context reflects the transient personal state of the customer at various touchpoints along the customer journey (Sandström et al. 2008). More precisely, extant CX(M) studies suggest that every human being is inherently subjective and informed by his or her own logic (i.e., way of thinking), a logic that is shaped by more than customer-brand/firm interactions (Helkkula 2011). In 62.94\% of the papers in our sample, the importance of the individual context is acknowledged (e.g., Hirschmann and Holbrook 1982; Holbrook and Hirschmann 1982; Sandström et al. 2008; Pucinelli et al. 2009).

First, several $\mathrm{CX}(\mathrm{M})$ researchers point out that one's emotional state - such as situational feelings of joy, happiness, and sadness - impacts the customer heavily (e.g., De Keyser et al. 2015). For instance, people in a good mood are typically more open to new products/services, whereas a bad mood often causes individuals to stick with familiar brands and be more receptive to negative clues in the environment (Puccinelli et al. 2009). Second, momentary cognitive factors - such as one's recalled previous experiences and memories - can strongly impact the customer journey by activating norms (e.g., things were better in the past) and/or goals (e.g., I want to relive something from my childhood) (e.g., Holbrook and Hirschman 1982; Grewal, Levy, and Kumar 2009; Puccinelli et al. 2009). For instance, a bad previous encounter might prevent a customer from re-engaging with a company's offering (Verhoef et al. 2009). And not only past and current experiences, but even future or imaginary experiences may affect the journey along different touchpoints and stages (e.g., Hirschman and Holbrook 1982, Jaakkola, Helkkula, and Aarikka-Stenroos 2015, Lemon and Verhoef 2016). 
In a similar vein, customers' readiness to engage in different stages along the customer journey will push or impede the progression of the experience (Sandström et al. 2008; Verleye 2015). Third, normative factors - internalized institutions, rules, thinking styles, processing strategies, and judgments - will have an important impact on CX as they steer customer attitudes and behaviors in important ways (Akaka, Vargo and Schau 2015). Finally, individual physical and economic factors also have an important situational impact. Fatigue and/or illness, for instance, may hinder a customer from pursuing a specific goal, while one's available budget determines consumption choices (De Keyser et al. 2015).

The social context is mentioned as an important CX component in around $22.38 \%$ of $\mathrm{CX}(\mathrm{M})$ studies, mainly considering the importance of social rules and norms activated by social groups (e.g., Schmitt 1999; Verhoef et al. 2009; Helkkula, Kelleher, and Pihlstrom 2012a, b; Bolton et al. 2018). In other words, the social context reflects the momentary conditions created by a customer's social relationships (Verhoef et al. 2009). Customers do not act in a social vacuum but largely share reality with their surroundings. They are surrounded by a multitude of other people (e.g., family members and friends) and collectives (e.g., families, cultural groups, or communities), making customers take on differing (social) roles that come with differing behavioral expectations that influence CX (De Keyser et al. 2015). All these people - whether or not included in collectives - have their own overlapping and contradictory goals, preferences, and needs, and the collectives, in turn, have their own overlapping and contradictory institutions (i.e., rules of social conduct) (Arnould and Price 1993; Åkesson et al. 2014). These latter strongly influence the way customers think and behave and what their socially constructed world looks like (Caru and Cova 2015).

In contrast to the individual and social context, extant $\mathrm{CX}(\mathrm{M})$ studies pay less attention to the market context $(10.49 \%)$ and the environmental context (6.99\%). Here, market context relates to the conditions created by market-related actors with which the customer interacts, 
including complements, competitors, substitutes, and future entrants in the market where the focal brand/firm is operating. Today, customers increasingly depend on networks of complementary, yet unrelated partners and channels that go beyond one focal brand/firm to find adequate solutions for their needs (e.g., Tax et al. 2013). At the same time, competitors, substitutes, and new entrants may also change experiences with a focal brand/firm. These actors may, for instance, create excitement (e.g., Payne et al. 2009) and even change customer goals, preferences, and needs by lowering prices (e.g., McColl-Kennedy et al. 2019). The environmental context, in turn, is composed of broader externalities that are natural, economic, public, or political in nature or a combination thereof. Natural environmental factors refer to factors such as weather and outside temperature (Lemon and Verhoef 2016). Economic environmental factors - such as income changes, gasoline prices, real estate value, GDP growth, and the state of the overall economy - also affect the customers" "frame of mind", as illustrated by their impact on customer brand preferences, what stores they visit, customers' willingness to buy products and services, and service purchase frequency (e.g., Kumar et al. 2014). Public factors - including road infrastructure, the power grid, and government support programs - may be of equal importance to the customer journey (McColl-Kennedy et al. 2012). Finally, political factors also deserve attention, in that political events may influence the value of consuming specific products or services (Lemon and Verhoef 2016).

\section{Building Block 3: Qualities}

A third key building block of CX relates to qualities. These qualities entail the set of distinctive attributes that reflect the nature of customer responses and reactions to interactions with the brand/firm (De Keyser et al. 2015; Keiningham et al. 2020). We distinguish five such qualities: participation level, dimensionality, timeflow, valence, and ordinariness.

The participation level of an experience reflects how active responses to brand/firm stimuli are (Pine and Gilmore 1998; Caru and Cova 2015). Some experiences require 
significant effort from customers, such as the NikeID website where customers can design their own shoes. In those situations, customers play a very active role. Contrary, other experiences may require little to no active involvement of the customer, such as attending a classical concert or listening to a lecture. Any experience, however, falls along a continuum from low (i.e., passive responses) to high participation (i.e., active responses) (Pine and Gilmore, 1998, Gentile, Spiller, and Noci 2007). Following the popularity of the co-production/co-creation literature and the spread of Service-Dominant Logic, the active role of the customer is increasingly acknowledged in the CX(M) literature (44.76\%).

The dimensionality of an experience - the most discussed and established CX quality in the literature - is derived from the differing type of responses that may flow from contacts between the brand/firm and customers across the customer journey (Lemon and Verhoef 2016). While early writings were dominantly focusing on the emotional side of CX in a plea to adopt an experiential instead of an information-processing view in marketing research (e.g., Holbrook and Hirschmann 1982; Hirschmann and Holbrook 1982; Thompson, Locander, and Pollio 1989), CX(M) researchers today recognize both views can co-exist by widely acknowledging the cognitive and emotional dimensions of CX (respectively $67.83 \%$ and $74.13 \%$ of the papers in our sample). Following the seminal work of Schmitt (1999), the dimensionality view expanded and many $\mathrm{CX}(\mathrm{M})$ studies also refer to the sensorial/physical (38.46\%), social/relational (27.27\%), and behavioral/pragmatic (28.67\%) dimensions of CX. Different clues associated with touchpoints may evoke these responses, which vary in strength and presence depending on the encounter (Berry, Carbone, and Haeckel 2002, Gentile, Spiller, and Noci 2007, Patricio, Fisk, and Cunha 2008, Schmitt, Brakus, and Zarantonello 2015). Based upon the $\mathrm{CX}(\mathrm{M})$ literature, we discern a continuum from unidimensional to multidimensional responses, with every individual dimension ranging from weak to strong activation. 
The timeflow of an experience is another inherent quality of CX, relating to how long or short an experience is in the judgement of the customer (Kranzbühler et al. 2018) and reflecting its perceived dynamics (i.e., tempo, speed, rhythm) (Woermann and Rokka 2015). As with the other qualities, timeflow depends on the subjective perception of the customer, which is situated on a continuum from short to long and monotone to dynamic. In other words, experiences range from in-the-moment, momentary experiences (e.g., a 30 second rollercoaster ride) to enduring, extended experiences (e.g., a transatlantic flight) that vary in dynamism (e.g., an easy flight versus a flight bothered by turbulence) (Schouten, McAlexander, and Koenig 2007, Chandler and Lusch 2015). Overall, duration and dynamism are covered in respectively $13.29 \%$ and $16.08 \%$ of the $\mathrm{CX}(\mathrm{M})$ papers.

The valence of an experience refers to the negative, neutral, or positive nature of customer responses to interactions with the brand/firm, with all three levels potentially holding value to the customer. A continuum may be discerned from negative to positive (Brakus, Schmitt, and Zarantonello 2009), however Schmitt (2010) points out that CXs can simultaneously be positive and negative (e.g., splurging on an expensive dinner, consuming a food indulgence, watching a horror movie). If $\mathrm{CX}(\mathrm{M})$ researchers refer to valence, they often refer to its positive nature $(22.38 \%)$, followed by its negative nature $(17.48 \%)$, but little attention goes to indifferent or neutral experiences $(2.80 \%)$.

The ordinariness of an experience reflects the level of "commonness" of customer responses to brand/firm interactions (Becker and Jaakkola 2020; Tumbat and Belk 2011). More precisely, any experience can be plotted on a continuum from ordinary to extraordinary. Ordinary experiences - such as weekly grocery shopping - are common, normal, frequent, dayto-day experiences that are low in intensity (mentioned in $16.78 \%$ of the papers). CXs of an extraordinary nature, in turn, are uncommon, infrequent, and extend beyond the realm of everyday life (e.g., bungee jumping), hence high in intensity (covered in 19.58\% of the CX(M) 
papers). Extraordinary experiences are often sought for the sake of novelty, surprise, or to break the daily grind (Scott et al. 2017) and have the potential to create memorable and unforgettable experiences (Arnould \& Price 1993, LaTour \& Carbone 2014).

\section{THE TCQ NOMENCLATURE: SCHOLARLY IMPLICATIONS}

The fine-grained analysis of CX(M) literature put forth a nomenclature built around three key building blocks: Touchpoints $(\mathrm{T})$ - differing in control, nature and stage; Context $(\mathrm{C})$ individual, social, market, and environmental; Qualities (Q) - participation level, dimensionality, valence, ordinariness and timeflow. In essence, every customer journey can be dissected into its various touchpoints (T), the context in which they are embedded (C) and the qualities they deliver (Q). Any TCQ combination results in a value judgement that motivates or demotivates customers to pursue the customer journey and their overall relationship with the organization.

The TCQ nomenclature brings granularity to the definition of CX as non-deliberate, spontaneous responses and reactions to offering-related stimuli embedded within a specific context by detailing (1) the attributes that reflect the nature of the 'responses and reactions' with the qualities $(\mathrm{Q})$ components, (2) the diversity in 'offering-related stimuli' with the touchpoint (T) components, and (3) the layered nature of the 'specific context' with the context (C) components. From the above discussion and data provided in Table 2, it is clear that extant research has dominantly focused on specific components linked to the TCQ building blocks, while largely omitting others.

In this section, we focus on needed research efforts to push the field forward (see Table 3) and propose the TCQ building blocks and their 12 components as distinct, yet linked research streams, which pave the way for future research. Based on the coverage of the components in the literature (see Table 2) and current trends in the $\mathrm{CX}(\mathrm{M})$ and service/marketing literature, we assess the state of research for every CX component and 
identify where opportunities lie. Note that some components are narrower by nature, explaining their lower coverage overall as there may be less research opportunities. Here, we focus on the areas we believe are most promising and needed to advance the CX(M) field.

\section{ADD TABLE 3 AROUND HERE}

\section{Touchpoints: Future Opportunities}

In relation to touchpoint control, $\mathrm{CX}(\mathrm{M})$ researchers increasingly recognize the uncontrollability of CX by a single brand/firm, as exemplified by the growing interest in the role of non-firm-controlled touchpoints - not in the least other customers and other brands/firms in service delivery networks (see also Table 2). This observation supports the notion of an ever-increasing complexity of the customer journey and the various parties external organizations, customers, social media influencers, etc. - that may impact CX. Indeed, several researchers point out that customers may act as a non-firm-controlled touchpoint by adopting the role of brand ambassadors through referral programs (Dose et al. 2019), influencers (Hughes, Swaminathan, and Brooks 2019) or sharing incentivized wordof-mouth through various offline and online media (Lamberton and Stephen 2016). Finally, brands and firms often engage in partnerships with other brands and firms, thereby giving these actors some control over touchpoints. Further inquiry is needed on the following questions: how does a customer's CX with non-firm-controlled touchpoints affect their experience with firm-controlled touchpoints? Under what conditions do interactions with non-firm-controlled touchpoints have positive/negative repercussions (e.g., the impact of other customers and social distancing in retail environments)? How can a brand/firm optimally deal with this complexity? Answering these questions would expand initial work by Kranzbühler, Kleijnen and Verlegh (2019) who focus on branded outsourcing as a strategic means to reduce dissatisfying touchpoints' impact on brand evaluations. A lab experiment could alter the ownership of and experience with various touchpoints and 
consider the respective impact on customers, while a longitudinal field study may help understand the financial impact of various touchpoint ownership strategies. The hospitality, healthcare and travel industries would be particularly relevant study contexts given their dynamic nature and the high prevalence of non-firm-controlled touchpoints here.

The challenge of dealing with non-firm-controlled touchpoints is especially prevalent in a sharing economy (Wirtz et al. 2019) - a setting largely ignored in CX(M) literature so far. A traditional hotel chain like Marriott, for instance, has full control on room design and cleanliness. Airbnb properties, on the other hand, display considerable variance, and much of the $\mathrm{CX}$ is left in the hands of the individuals hosting their properties on the platform (Eckhardt et al. 2019). Research by Hazée, Delcourt, and Van Vaerenbergh (2017) shows that customers make various extra considerations before dealing with sharing platforms and have concerns about the non-firm-controlled nature of aspects of sharing services (e.g., reliability of other users, potential contamination by others, liability due to other users). Research is needed to understand CX formation in these multi-actor settings (Eckhardt et al. 2019). How different is CX in multi-actor settings, such as sharing platforms? How do interactions with various actors impact each other? To what extent do customers distinguish between the sharing platform (e.g., Airbnb) and other providers (e.g., host)? Qualitative research could provide new and deep insights into these questions. Digital technologies that capture multiactor settings could enable deeper analyses of these settings. Additionally, researchers can develop experiments showcasing scenarios in which sharing platforms employ differential levels of control and measure $\mathrm{CX}$ formation. CX researchers may benefit from collaborating with social psychology or sociology researchers, as they may have insight into how actors interact with one another in complex networks.

With regard to touchpoint nature, more research is needed to understand the dynamic interplay between touchpoints of different nature (Bolton et al. 2018), looking into what 
specific type(s) of touchpoints are most effective early/late in the customer journey, what moderates the effectiveness of touchpoints with a different nature, and whether different touchpoint type paths result in distinctly different outcomes. The COVID-19 pandemic has also shifted traditionally physical experiences to entirely digital, even if they are not wellsuited to a virtual approach. Much research is needed to understand how this shift has changed the CX for both firms and consumers, as well as how adaptations to physical (e.g., presence and obliged usage of disinfecting gels) and human (e.g., usage of protective masks) touchpoints impact customers (and employees).

Singh et al. (2017) also raise several interesting sub-aspects of touchpoint nature that largely reflect the intersection between interactions (e.g., complexity) and interfaces (e.g., richness, synchronicity) in the context of organizational frontlines. It is especially the interface component (i.e., the characteristics of a touchpoint - hence reflecting its nature) that is ripe for new research as new technologies are rapidly enhancing touchpoint interfaces, making them the new frontiers of "value creation and profit" (Goodwin 2015).

Specifically, with the rise of AI, new technologies like virtual/augmented reality, and the fast adoption of smart assistants and service robots, the nature of a touchpoint will become increasingly blurred (Lemon 2016). Lowe's augmented reality solution, for instance, allows customers to add a virtual layer to an in-store physical model kitchen with the help of an employee, Google Assistant is able to make calls as if it were a human, and robots are increasingly being anthropomorphized (De Keyser et al. 2019). Research should consider how the blurred nature of touchpoints impacts CX. When do customers prefer a different touchpoint nature? What aspect - human, physical, digital - dominates the CX? How do distinct 'blurred' combinations impact CX? To what extent do customers want to be aware of the true nature of a touchpoint (e.g., human vs digital) (Robinson et al. 2020). Inspiration for field/lab experiments may be drawn from Luo et al. (2019) as one of the first studies to 
provide evidence for negative effects of disclosing the true nature of a touchpoint in financial services sales setting. CX research in this area may profit from setting up collaborations with researchers from other fields including AI, information systems and the robotics area.

With regards to touchpoint stage, we note that little research considers the linkage between the various stages of the customer journey (despite recognizing their occurrence) and how firms should spread their efforts to enhance CX to enable customers to successfully bridge these stages (Voorhees et al. 2017). While CX investments in the pre-purchase stage may boost awareness and consideration efforts, these may draw managerial attention and resources away from the later stages thereby potentially decreasing eventual repurchase and repeat buyer behavior, and vice versa. Voorhees et al. (2017) raise the examples of Amazon investing strongly in the pre-purchase phase through recommendation agents versus Zappos putting emphasis on return policies to ensure happy clients. Insights into the importance of different stages for the overall CX across settings is needed to support firms/brands to optimally balance their investments and resources across the three stages of the customer journey. To investigate, researchers can opt for conjoint analyses where respondents are introduced to choice sets featuring different levels of resource investments across the three stages and explore how this affects their CX.

Zooming-in on the individual stages, the emergence of big-data-driven microtargeting is expected to especially change the pre-purchase stage, altering the traditional need recognition/consideration set/evaluation funnel into an effortless whole (André et al. 2018). Netflix, for instance, dramatically simplifies content selection by proposing content that any of its individual subscribers are likely to enjoy based on previous behaviors. Similarly, digital advertisers are putting in place ad-scheduling strategies at an individual level (Todri, Ghose, and Singh 2019), while smart assistants such as Amazon's Alexa and Google's Assistant have the ability to learn and predict users' needs and preferences and eventually automate 
consumption decisions (De Keyser et al. 2019). Such a transformation raises a whole new set of questions related to $\mathrm{CX}$ formation: How do rapid automation and micro-targeting practices impact CX? How do customers develop trust in agents and smart assistants such that they are willing to give up autonomy and follow these actors? To gain insight, researchers may benefit from observing how customers respond to recommender agents in online retail environments or smart assistants at home through netnographic and/or ethnographic research. Given the availability of big data in this area, researchers can collaborate with firms to develop finely tuned attribution models to examine how smart technologies and AI influence the entire customer journey, and how to optimize use of new marketing and ad tech opportunities. To anticipate further AI-based advancements, researchers may also benefit from collaborations with operations management and information systems scholars.

\section{Context: Future Opportunities}

In contrast to the individual and social context, the market and environmental context are largely ignored (see Table 2). Hence, significant opportunities remain to consider how the large set of contextual factors impact CX. These opportunities will continue to expand as big data and new technologies are enabling brands/firms to have more information than ever before about the context in which the customer journey is embedded at each of the four levels (Thomadsen et al. 2018). While practitioner-oriented work increasingly recognizes that brands/firms may profit from contextual insights (e.g., Siggelkow and Terwiesch 2019), much still remains unknown on how and in what way contextual information may transform business practices. More specifically, future research may consider how (new) contextual information can influence CX strategies and may give rise to new business models. Uber, for instance, strongly builds on geo-localization to connect drivers and riders, determine prices and communicate service specifics such as estimated time 
to pick-up to its users. More insights are needed to determine how and in what way(s) brands/firms may systematically make use of contextual insights to enhance CX.

Given the plethora of contextual data that may be relevant, research will also be needed to support brands/firms in selecting the most appropriate contextual data. It is unlikely all contextual factors are equally important across consumption situations. Therefore, we call for more work looking into new ways to rank-order and select critical contextual information, what contextual data should be prioritized to use along the customer journey and at what level of aggregation brands/firms should best collect, analyze and use contextual data. Gridwise, an application designed to assist rideshare drivers, for instance, has done great work in this area, providing and sorting real-time contextual information to boost driver earnings in a specific area, including airport information (e.g., no. of passengers arriving), event listings, and weather data. This prioritization of contextual information helped increase average driver earnings by 39\% (Mericle 2018). A multiple case study design (Verleye 2019) may allow insight into how different types of businesses (e.g., online retailers vs insurance companies) use contextual information to boost $\mathrm{CX}$ along with its financial implications.

Similarly, work is needed to understand trade-offs between personalization and privacy considerations (Aguirre et al. 2015; Bleier, De Keyser, and Verleye 2018). Moreover, various legal frameworks such as Europe's GDPR that limit data collection and/or usage may change customers' awareness of privacy issues. Various research questions appear: How should companies collect contextual information? What level of transparency is required? How far can companies go in deploying contextual data taking into the account the personalization-privacy paradox? Here, cross-national comparative case analyses may allow to gain insight into the impact of various legal frameworks on the usability of contextual data and their performance implications from a customer and firm perspective. 
Finally, we need more work to understand how major and sudden environmental changes such as the COVID-19 pandemic may alter CX(M). Brands/firms as well as customers worldwide are facing an unprecedented crisis, changing their spending patterns as they are facing uncertainties related to their health and income. Research will be needed to understand how this alters customer expectations and how brands/firms need to respond to deliver valuable experiences to their customer bases.

\section{Qualities: Future Opportunities}

The most established quality is CX dimensionality, which is recognized in most CX definitions to date. The dominant $\mathrm{CX}$ stream now recognizes five $\mathrm{CX}$ dimensions emotional/affective, cognitive/mental, physical/sensorial, and social/relational, and behavioral/pragmatic (e.g., Brakus, Schmitt, and Zarantonello 2009; Lemon and Verhoef 2016). However, more research is still needed to better detail the social, sensorial and behavioral aspects of CX and how they work in combination with the cognitive and emotional dimension (Mahr et al. 2019). In addition, more work is needed to understand the importance of each dimension, how this varies across distinct situations (i.e., is there such a thing as an optimal level?) and how brands/firms may better trigger each individual dimension and/or combination. Experimental work as well as conjoint analyses may help support research in answering these questions.

With regard to the role of customer participation, future work could look into how differing levels of participation across the customer journey impact CX, and the boundary conditions that drive customer preferences for high vs low levels of participation (i.e., how active do customers want to be?). A company like Ikea, for instance, has been rethinking its model in the last few years. Whereas customer participation is still high for many of its customers (i.e., picking-up and assembling furniture is done by the customer), they have 
added design, delivery and assembly services in partnership with TaskRabbit that allow customers to interact with Ikea in a rather passive manner, broadening the Ikea CX options.

Ordinariness/extraordinariness and timeflow received less attention than the other qualities in the $\mathrm{CX}(\mathrm{M})$ literature. While both find more traction in fields closely related to CX, including research on flow (Novak, Hoffman, and Yung 2000) and time perceptions (Durrande-Moreau and Usunier 1999), CX research should devote more attention to both qualities. Interesting research opportunities include: When do consumer prefer ordinary experiences? In light of COVID-19, how do seemingly ordinary experiences like grocery shopping change in nature? When can the often-hyped extraordinary experiences (e.g., Pine and Gilmore 1998) negatively impact value perceptions? How do the different time aspects duration, variation, speed, rhythm - impact CX at various stages of the customer journey? How is perceived timeflow different depending on the valence of the CX? To answer such questions, researchers can conduct diary studies in a setting where service providers have long-term customer relationships- such as healthcare- to examine the incidence, duration and impact of (extra)ordinary experiences on overall service evaluations and behavioral outcomes.

Despite some notable exceptions (e.g., Scott, Cayla, and Cova 2017), valence and its role in $\mathrm{CX}$ formation is also largely ignored in CX research. Meanwhile, the link between the valence of experiences and a number of evaluative outcomes, such as satisfaction and valuein-use deserves further investigation. Of particular interest could be the identification of experiences that customers prefer to be indifferent as not every CX may need to be highly positive (Becker and Jaakkola 2020). Following the possible co-activation of positive, negative and/or neutral feelings (Andrade and Cohen 2007), future research can also explore the ambivalent nature of experiences and its implications for evaluative customer outcomes. The latter type of research is especially interesting in contexts where brands or firms invest in 
generating positive experiences while the core product or service triggers negative experiences (e.g., pain in hospitals and fear in horror movies). The extent to which brand/firms can manage these ambivalent experiences might contribute to a better understanding of CX.

\section{THE TCQ NOMENCLATURE: METHODOLOGICAL CHALLENGES}

From a TCQ perspective, the field faces some methodological challenges linked to each building block individually, and to their connections. In this section, we seek to provide guidance on how CX researchers may match their efforts with the TCQ nomenclature, while also building on an analysis of the meta-data found in $\mathrm{CX}(\mathrm{M})$ literature.

In relation to $\mathrm{CX}$ touchpoints and the customer journey in general, we observe that much service and marketing research currently focuses on individual touchpoints in a retail setting (see Table 4). However, there is a lack of longitudinal research designs to create insights across different touchpoints and journey stages (Lemon and Verhoef 2016). The use of (mobile) diary studies (MacDonald, Wilson, and Konus 2012) and attribution modeling techniques (Kannan, Reinartz, and Verhoef 2016) in conjunction with journey mapping and service blueprinting (Bitner, Ostrom and Morgan 2008) efforts can be highly beneficial to overcome the dominant static view, allowing to capture CX dynamics across touchpoints of different nature, control and stage. Case study research, in turn, may offer insight into how and why companies change touchpoints along customer journeys over time, thereby taking its implications for customers, firms, and other stakeholders into consideration (Verleye 2019).

Significant opportunities for context related CX work may lie in adopting a design thinking approach (currently underrepresented in CX research - see Table 5), by which researchers and practitioners gather information about the four distinct contextual levels and use this information to design new CX practices. Further, while qualitative research pointed at contextual influences (see Table 5), these influences are not well-understood. New 
technologies are opening many possibilities for data fusion from various offline and online sources (Thomadsen et al. 2018). Mobile and smart technologies enable the capture and collection of contextual data through myriad sensors and trackers, which enables firms to gain insight into the individual, social, environmental, and market context in a reliable and objective manner (Verhulst et al. 2019). The rise of wearable devices offers ample opportunities to collect individual context data such as one's daily activity rating (i.e., number of steps, calories, sleep hours, pulse rate) and health condition. Smartphones enable data collection on multiple levels, including the individual (e.g., personal calendar), social (e.g., social connections), and environmental (e.g., geo-localization) levels - or context combinations, such as Apple's new partnerships with local gyms to enable consumers to track workouts and earn rewards (Haselton 2020). People themselves also reveal context-related information through their social media accounts, including likes, shares, posts, and comments that they often grant brands/firms access to through usage of specific apps. Finally, other tools like eye trackers, haptic devices, motion sensors and microphones allow researchers to develop an understanding of what contextual elements are actually experienced in an objective manner (Verhulst et al. 2019). In this area, it may also be helpful to build on insights from environmental and social psychology, behavioral economics, and management literature, which have a tradition of looking at broader contextual influences.

Looking at CX qualities, the dominant focus has been on measuring the dimensionality component (Gahler, Klein and Paul 2019), while other qualities received less research and measurement attention. Moreover, measuring of CX dimensionality typically relies on one of the CX-scales developed in the literature focusing mostly on brands (e.g., Brakus, Schmitt, and Zarantonello 2009; Schouten, McAlexander, and Koenig 2007) and services (e.g., Klaus and Maklan 2012; Verleye 2015). To our knowledge, no paper exists trying to develop an all-encompassing measurement tool to grasp all CX qualities in a holistic 
manner, as well a tool that allows CX to be captured in a dynamic manner across the customer journey. We believe that any tool to capture CX should be tailored to the specific context (as called for by Hamilton 2016 and Houston 2016). It is time to move beyond the dominant focus on survey research (see Table 6). Potential lies in new techniques like text mining (e.g., McColl-Kennedy et al. 2019), image mining (e.g., Ordenes and Zhang 2019) and neuroscience (e.g., Verhulst et al. 2019), in addition to conjoint analysis, econometric modelling, big data analysis (e.g., Kumar et al. 2014), and established qualitative research methods - like phenomenological, ethnographic, and case study research (Verleye 2019).

\section{INSERT TABLES 4 \& 5 AROUND HERE}

In addition, B2C research is dominant (see Table 6) with over $91 \%$ of research solely focusing on individual customers. While the authors believe that the insights generated from this stream of research may apply in B2B settings (indeed, the B2B-only articles in our sample largely build on $\mathrm{B} 2 \mathrm{C}$ work), there is a need for research to consider how $\mathrm{CX}$ differs in a B2B environment (notable exceptions include McColl-Kennedy et al. (2019), Roy et al. (2019), and Zolkiewski et al. (2017)), and to what extent the TCQ nomenclature is fully applicable to B2B settings and/or needs to be extended. While most of the TCQ components were identified by the B2B-specific papers (except timeflow, valence and ordinariness), more research is needed in this area to further develop knowledge on B2B CX specifically.

\section{INSERT TABLE 6 AROUND HERE}

Finally, the $\mathrm{CX}(\mathrm{M})$ literature is largely restricted to Western cultures (e.g., USA, UK, Portugal), while limited research focuses on non-Western cultures (e.g., China, India) - see Table 7. Moreover, no study in our sample looked at the impact of cultural differences on CX. This is surprising as culture as a contextual variable is a strong determinant of the values customers hold, the goals they pursue, and the ways customers perceive and interpret their 
environment (Shavitt and Barnes 2019). As such, CX research in a larger variety of cultures is necessary to gain a better understanding of how different cultures appreciate various components of CX. For example, what dimensions of CX do people from Western vs nonWestern cultures attach more importance to? Does culture predict how customers react to changes in touchpoint nature? Does culture impact how various other contextual influences like the weather, competitor actions, and economic climate impact CX? Providing an answer to these and other questions would be of great importance to companies seeking to expand their business to different cultural regions and/or adapt their offering to various ethnic groups (Shavitt and Barnes 2020), while also expanding the cultural richness and inclusivity of the CX field.

INSERT TABLE 7 AROUND HERE

\section{THE TCQ NOMENCLATURE: MANAGERIAL OPPORTUNITIES}

Experience design is not new and has been promoted since the early '90's (Carbone and Haeckel 1994). The idea generally boils down to creating a setting in which experiences are created in a favorable way to close the gap between intended and perceived CX (Ponsignon, Durrieu, and Bouzdine-Chameeva 2017). As more data becomes available, a new world opens to companies to design experiences. However, a large majority of CX professionals struggle to develop clear CX practices (HBR Analytic Services 2017) and CX performance has been plateauing (Forrester 2019). One key reason is lack of knowledge about CX and the subsequent lack of support from top management (Davey 2019). We posit that the introduction of the TCQ nomenclature may provide a path forward as it provides practitioners with a new, simple lens to view CX. A key advantage of the TCQ nomenclature is its ability to make CX actionable and to help define the content of intended CXs (Jaakkola and Becker 2020). Here we discuss two specific aspects of CXM that would significantly benefit from our approach: the $\mathrm{CX}$ audit process and $\mathrm{CX}$ design and innovation. 
CX Audit. In order to identify specific opportunities to strengthen the current CX or to identify critical pain points, many firms periodically audit their customer journey and delivered CX (Kuehnl, Jozíc, and Homburg 2019). The TCQ nomenclature may help to improve the $\mathrm{CX}$ audit process, provide a common language to underlie such efforts, and move firms more quickly to actionable improvement.

1. Streamline the touchpoint overview. A initial step of a TCQ-informed audit would have managers making an inventory of the touchpoints (i.e., nature? control? stage?) that the brand/firm has with their customers as well as an assessment of their connectivity (i.e., how easy is it to move from one touchpoint to another?) and consistency (i.e., do experiences match across touchpoints?) (Homburg, Jozíc, and Kuehnl 2017). Specifically, CX managers should list all human, physical and digital touchpoints - whether or not controlled by the firm - in the pre-purchase, purchase, and post-purchase stage of the customer journey. Tools like customer journey mapping (Rosenbaum, Otalora and Ramírez 2017) and service blueprinting (Bitner, Ostrom and Morgan, 2008) provide the basis to kickstart the TCQ audit.

2. Recognize context. Subsequently, an assessment is needed as to what contextual influences are at play across the various touchpoints, the extent to which current touchpoints are context-adaptive, and what sources the brand/firm currently uses to capture contextual data.

3. Assess all delivered qualities. Third, the various touchpoints along the customer journey need to be assessed in terms of their qualities and the value they provide. Tools like customer surveys and real-time experience tracking (Macdonald, Wilson, and Konus 2012) may help in this effort. By linking data about CX qualities to data associated with the evaluative judgments (such as measures of customer satisfaction and NPS scores), CX managers can further assess the relative importance of CX 
qualities and the potential for improvement (i.e., driver analysis) across touchpoints (Keiningham et al. 2020).

4. Evaluate, benchmark and move to action. By combining the information gathered across these three steps, the TCQ nomenclature allows a common vocabulary to analyze, evaluate and discuss existing $\mathrm{CX}$ practices, while also providing a starting point to develop competitor benchmarks. The audit will most likely reveal strengths, weaknesses, opportunities, and threats that exist in the current CX. Mere identification, though, is insufficient. The value of the TCQ approach is that it provides a sufficient level of detail and specificity - what touchpoint, what specific quality within that touchpoint, and in what context - to enable managers to quickly "fix", "improve" or "remove" that particular aspect of the touchpoint that will result in an improved CX. It is the identification of the TCQ combinations that offers the best opportunities for action. For example, a customer pain point may be identified at a specific touchpoint that takes too long (timeflow quality) or is too mentally taxing (cognitive quality). This issue can quickly be rectified by clear operational changes, or an improvement opportunity may be identified to make a specific touchpoint experience more positive (valence quality) when it occurs in a specific (e.g., social) context.

CX Innovation and Design. The TCQ nomenclature will also strengthen CX design, whether innovating existing CX, designing new touchpoints, or designing entire new customer journeys. Traditional customer journey work typically starts with the existing or desired customer touchpoints. However, recognizing that touchpoints are only one building block of CX, this approach enables firms to start with qualities or context. Specifically, rather than starting from existing touchpoints and evaluating how customers value the delivered qualities (what is currently done most often), managers may consider what experience qualities 
customers are looking for and then gather the necessary contextual data to enable these qualities at appropriate touchpoints.

1. Determine desired experience qualities. More concretely, in a first step, managers may assess the desired experience qualities of customer responses at various points along the customer journey. Tools such as customer surveys, ethnography, netnography, and depth interviews may help gain insights into the desired qualities, identifying the extent to which each quality - level of participation, multidimensionality, timeflow, valence, and ordinariness - is potentially important (or unimportant) at each journey stage and valued by the customer (Keiningham et al. 2020). An example is the beauty firm, Glossier. Prior to selling products, the firm (through its blog and Instagram) got feedback from customers regarding the specific qualities desired in their products and service processes. Only once the firm had sufficient insight from customers did they begin selling their products to consumers and designing the overall CX. With over $\$ 100$ million in sales in 2018 , they continue to innovate and refine their products' qualities and their overall $\mathrm{CX}$ by seeking customer feedback through their "Into the Gloss" website and their Instagram account.

2. Assess need for contextual information. Second, an assessment is needed as to what contextual data can and/or should be collected to be able to create those touchpoints that allow specific qualities to occur. Managers are now confronted with an abundance of possibilities to grow their contextual understanding and may build on the earlier identified plethora of context-aware technologies. The challenge broadly lies in selecting the most relevant contextual information. These data provide a rich source of information that can help enhance the value of the firms' actions and offerings through increased personalization and contextualization. 
3. Determine touchpoint constellation. In a third step, managers need to assess what type of touchpoint constellation (i.e., combination of touchpoints) is best to promote the sought-after qualities, and check whether existing touchpoints may be adapted or whether new touchpoints need to be introduced. Here, the trade-off between having touchpoint control or not is also critical, considering the inherent nature dissatisfying, neutral, satisfying - of the touchpoint and the impact it may have on the brand/firm (Kranzbühler, Kleijnen, and Verlegh 2019).

4. Move to Action: Experiment, assess, iterate. This iterative process leads to a list of potential opportunities to innovate and differentiate CX. From this, managers must select the actions that are most likely to be successful given their setting and customer base. Experimentation, prototyping, and choice modeling can assist managers in making the selection (Almquist, Senior, and Bloch 2016). The simple, clear TCQ nomenclature quickly enables firms to design unique combinations of TCQ that solve customer problems and differentiate firms from the competition.

Taken together, we believe the TCQ-nomenclature may hold significant value for practitioners in providing a common language to discuss CX management, design and innovation. It is critical for managers to understand their customers and what they desire. A TCQ-informed vision may help to see the forest for the trees. Table 8 provides a TCQinspired checklist for CX managers.

\section{ADD TABLE 8 AROUND HERE}

\section{CONCLUSION}

In this paper, the TCQ nomenclature is introduced as a standardized lens to view CX. Its main contribution lies in moving from a focus on individual aspects of CX to integrating all key components of CX (MacInnis 2011). Specifically, following an inductive analysis of the $\mathrm{CX}(\mathrm{M})$ literature, this investigation finds that $\mathrm{CX}$ is comprised of three building blocks: 
touchpoints, context, and experience qualities. The value of the nomenclature lies in enabling brands/firms and researchers to link the building blocks and their components in ways that have not been considered before. In this sense, a dialectical integration takes place that may help move the field forward and reduce the misunderstanding and difficulties in managing CX.

In addition, the TCQ nomenclature helped identify gaps in the existing literature and points to various (methodological) ways forward. As a result, CX scholars can accelerate empirical research that addresses the various challenges managers face (by connecting with other fields/disciplines, using novel methodologies, and linking the TCQ elements with behavioral and financial outcomes).

Finally, the TCQ framework may support managers in their efforts to develop a better understanding of CX through TCQ-informed brand/firm audits and approaches to innovation. Applying TCQ to identify novel combinations of touchpoints, contexts, and qualities will provide new opportunities for firms to differentiate their offerings and to improve the experience of customers. 
Table 1. CX Review Studies

\begin{tabular}{|c|c|c|c|c|c|}
\hline Study & Study Goal & Study Method & Key Findings & $\begin{array}{l}\text { Differences from } \\
\text { present study in terms } \\
\text { of research process }\end{array}$ & $\begin{array}{l}\text { Differences from present } \\
\text { study in terms of outcome }\end{array}$ \\
\hline $\begin{array}{l}\text { Helkkula } \\
\text { (2011) }\end{array}$ & $\begin{array}{l}\text { Review of the } \\
\text { characterization of the } \\
\text { concept of service } \\
\text { experience }\end{array}$ & $\begin{array}{l}\text { Systematic literature } \\
\text { review }(n=32)\end{array}$ & $\begin{array}{l}\text { Three characterizations of service } \\
\text { experience: (a) phenomenological, (b) } \\
\text { process-based, and (c) outcome-based } \\
\text { service experience. }\end{array}$ & $\begin{array}{l}\text { - Narrower timeframe } \\
\text { (2005 to 2007) } \\
\text { - Narrower scope (i.e., } \\
\text { focus on service } \\
\text { experience) }\end{array}$ & $\begin{array}{l}\text { - } \text { Distinct focus (i.e., } \\
\text { identification of CX } \\
\text { research streams) } \\
\text { - Lack of nomenclature } \\
\text { - No clear CXM guidelines } \\
\text { - No link with CX meta-data }\end{array}$ \\
\hline $\begin{array}{l}\text { Rose et al. } \\
\text { (2011) }\end{array}$ & $\begin{array}{l}\text { Review of antecedents } \\
\text { and outcomes of online } \\
\text { CX }\end{array}$ & $\begin{array}{l}\text { Systematic literature } \\
\text { review }(\mathrm{n}=120)\end{array}$ & $\begin{array}{l}\text { Identification of online } \mathrm{CX} \text { antecedents } \\
\text { and consequences in the form of a } \\
\text { testable, holistic framework. }\end{array}$ & $\begin{array}{l}\text { Narrower timeframe } \\
(1985-2009) \\
\text { - Narrower scope (i.e., } \\
\text { focus on online CX) }\end{array}$ & 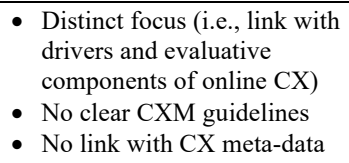 \\
\hline $\begin{array}{l}\text { De Keyser et } \\
\text { al. (2015) }\end{array}$ & $\begin{array}{l}\text { Interdisciplinary } \\
\text { discussion on } \\
\text { (customer) experience, } \\
\text { and development of } \\
\text { foundational premises } \\
\text { underlying CX }\end{array}$ & $\begin{array}{l}\text { Selected literature } \\
\text { review (philosophy, } \\
\text { psychology, } \\
\text { sociology, business, } \\
\text { management fields) }\end{array}$ & $\begin{array}{l}\text { Formulation of unified CX definition, } \\
\text { identification of four fundamental } \\
\text { properties, and delineation of CX to } \\
\text { customer value and engagement. }\end{array}$ & $\begin{array}{l}\text { - No systematic } \\
\text { literature review } \\
\text { process }\end{array}$ & 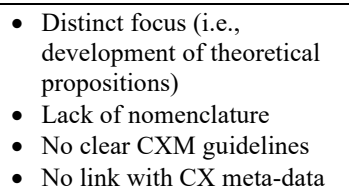 \\
\hline $\begin{array}{l}\text { Lemon and } \\
\text { Verhoef } \\
\text { (2016) }\end{array}$ & $\begin{array}{l}\text { Examination of the } \\
\text { roots and origins of } \mathrm{CX} \\
\text { research }\end{array}$ & $\begin{array}{l}\text { Selected literature } \\
\text { review }\end{array}$ & $\begin{array}{l}\text { Formulation of three key research } \\
\text { domains in the CX field: (a) CX and } \\
\text { the customer journey, (b) CX } \\
\text { measurement, and (c) CXM. }\end{array}$ & $\begin{array}{l}\text { - No systematic } \\
\text { literature review } \\
\text { process }\end{array}$ & $\begin{array}{l}\text { - Distinct focus (i.e., } \\
\text { identification of CX origins } \\
\text { and development of } \\
\text { dynamic CX framework) } \\
\text { - Lack of nomenclature } \\
\text { - No clear CXM guidelines } \\
\text { - No link with CX meta-data }\end{array}$ \\
\hline $\begin{array}{l}\text { Lipkin } \\
\text { (2016) }\end{array}$ & $\begin{array}{l}\text { Review of customer } \\
\text { experience formation } \\
\text { and its theoretical } \\
\text { grounds }\end{array}$ & $\begin{array}{l}\text { Systematic literature } \\
\text { review }(n=163)\end{array}$ & $\begin{array}{l}\text { Three theoretical underpinnings for } \\
\text { how individuals realize CX at the } \\
\text { individual level (stimulus-, interaction-, } \\
\text { and sense-making-based) and three } \\
\text { contextual lenses setting the boundaries } \\
\text { of CX formation (dyadic, service } \\
\text { ecosystem, and customer ecosystem). }\end{array}$ & $\begin{array}{l}\text { - Narrower timeframe } \\
\text { (1998 to 2015) } \\
\text { - Narrower scope (i.e., } \\
\text { focus on service } \\
\text { experience) }\end{array}$ & $\begin{array}{l}\text { - } \text { Distinct focus (i.e., } \\
\text { identification of CX } \\
\text { research streams) } \\
\text { - Lack of nomenclature } \\
\text { - No clear CXM guidelines } \\
\text { - No link with CX meta-data }\end{array}$ \\
\hline $\begin{array}{l}\text { Jain et al. } \\
\text { (2017) }\end{array}$ & $\begin{array}{l}\text { Review of CX } \\
\text { literature }\end{array}$ & $\begin{array}{l}\text { Systematic literature } \\
\text { review }(\mathrm{n}=82)\end{array}$ & $\begin{array}{l}\text { Clarification of the similarities, } \\
\text { differences, and relationship between } \\
\text { service experience and CX. }\end{array}$ & $\begin{array}{l}\text { - Narrower timeframe } \\
\text { (1990 to 2015) } \\
\text { - Narrower scope (i.e., } \\
\text { focus on CX and } \\
\text { service experience) }\end{array}$ & 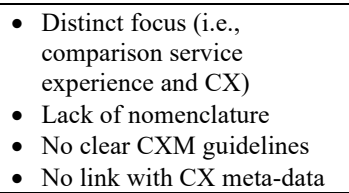 \\
\hline $\begin{array}{l}\text { Kranzbühler } \\
\text { et al. (2018) }\end{array}$ & $\begin{array}{l}\text { Classification and } \\
\text { examination of CX } \\
\text { research from an } \\
\text { organization and } \\
\text { customer perspective }\end{array}$ & $\begin{array}{l}\text { Systematic literature } \\
\text { review }(n=115)\end{array}$ & $\begin{array}{l}\text { Identification of two CX study levels } \\
\text { (static vs dynamic) and theoretical } \\
\text { perspectives (organizational and } \\
\text { customer) }\end{array}$ & $\begin{array}{l}\text { - Narrower timeframe } \\
\text { (1982 to 2015) }\end{array}$ & $\begin{array}{l}\text { - Distinct focus (i.e., } \\
\text { comparison of static versus } \\
\text { dynamic perspectives on } \\
\text { CX) } \\
\text { - Lack of nomenclature } \\
\text { - No clear CXM guidelines } \\
\text { - No link with CX meta-data }\end{array}$ \\
\hline $\begin{array}{l}\text { Mahr et al. } \\
\text { (2019) }\end{array}$ & $\begin{array}{l}\text { Review of concepts } \\
\text { and theories underlying } \\
\text { customer service } \\
\text { experience and its } \\
\text { underlying dimensions } \\
\text { (physical, social, } \\
\text { cognitive, affective and } \\
\text { sensorial) }\end{array}$ & $\begin{array}{l}\text { Systematic literature } \\
\text { review through text } \\
\text { mining }(n=258)\end{array}$ & $\begin{array}{l}\text { Identification of three focal research } \\
\text { areas (service system architecture, } \\
\text { servicescape, outcome measures) }\end{array}$ & 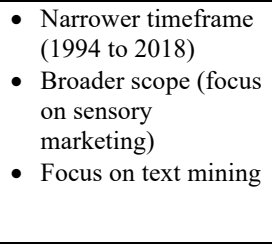 & $\begin{array}{l}\text { - } \text { Distinct focus (i.e., } \\
\text { identification of CX } \\
\text { research streams) } \\
\text { - Lack of nomenclature } \\
\text { - No clear CXM guidelines } \\
\text { - No link with CX meta-data }\end{array}$ \\
\hline $\begin{array}{l}\text { Becker and } \\
\text { Jaakkola } \\
(\mathbf{2 0 2 0})\end{array}$ & $\begin{array}{l}\text { Development of } \\
\text { foundational premises } \\
\text { underlying CX }\end{array}$ & $\begin{array}{l}\text { Systematic literature } \\
\text { review }(n=136)\end{array}$ & $\begin{array}{l}\text { Identification of eight study fields } \\
\text { underlying CX in marketing, grouped } \\
\text { by a positivistic vs interpretive research } \\
\text { tradition, and the development of four } \\
\text { fundamental premises of CX }\end{array}$ & $\begin{array}{l}\text { - Narrower timeframe } \\
\text { (1982 to 2016) } \\
\text { - Narrower scope (only } \\
\text { B2C papers) }\end{array}$ & $\begin{array}{l}\text { - Distinct focus (i.e., } \\
\text { development of holistic } \\
\text { framework with theoretical } \\
\text { propositions) } \\
\text { - Lack of nomenclature } \\
\text { - No clear CXM guidelines } \\
\text { - No link with CX meta-data }\end{array}$ \\
\hline $\begin{array}{l}\text { Present } \\
\text { paper }\end{array}$ & $\begin{array}{l}\text { Development of } \\
\text { nomenclature and } \\
\text { method analysis of the } \\
\text { CX research to push } \\
\text { the empirical and } \\
\text { managerial progress of } \\
\text { the CX field }\end{array}$ & $\begin{array}{l}\text { Systematic literature } \\
\text { review (1982 to } \\
\text { January 2020; } \\
n=143 \text { ) }\end{array}$ & $\begin{array}{l}\text { Identification of three key CX building } \\
\text { blocks - touchpoints, context, quality, } \\
\text { each with a respective set of } \\
\text { components that together form the } \\
\text { basis of a formal CX nomenclature, } \\
\text { and the lack of methodological variety } \\
\text { and sophistication preventing further } \\
\text { progress in the field. }\end{array}$ & $\begin{array}{l}\text { This paper: } \\
\text { - Systematic literature } \\
\text { review process } \\
\text { - Extended timeframe } \\
\text { (1982 to Jan. 2020) }\end{array}$ & $\begin{array}{l}\text { This paper: } \\
\text { - Introduction of CX } \\
\text { nomenclature built around } 3 \\
\text { key building blocks: } \\
\text { Touchpoints, Context, } \\
\text { Qualities } \\
\text { - Clear CXM guidelines } \\
\text { - Link with CX meta-data } \\
\text { - Discussion of } \\
\text { methodological challenges } \\
\text { for (empirical) CX research }\end{array}$ \\
\hline
\end{tabular}


Table 2. TCQ coverage in the $C X(M)$ literature ( $n=143$ articles)

\begin{tabular}{|c|c|c|c|}
\hline Building Block & \multicolumn{2}{|c|}{ Component } & Coverage in literature $(\%)$ \\
\hline \multirow{3}{*}{ Touchpoints } & Control & $\begin{array}{l}\text { firm-controlled } \\
\text { non-firm-controlled }\end{array}$ & $\begin{array}{c}100.00 \% \\
46.85 \%\end{array}$ \\
\hline & Nature & $\begin{array}{l}\text { human } \\
\text { physical } \\
\text { digital }\end{array}$ & $\begin{array}{l}41.96 \% \\
40.56 \% \\
33.57 \%\end{array}$ \\
\hline & Stage & $\begin{array}{l}\text { pre-purchase } \\
\text { purchase } \\
\text { post-purchase }\end{array}$ & $\begin{array}{l}36.36 \% \\
37.06 \% \\
39.86 \%\end{array}$ \\
\hline Context & $\begin{array}{l}\text { Individual } \\
\text { Social } \\
\text { Market } \\
\text { Environmental }\end{array}$ & & $\begin{array}{c}62.94 \% \\
22.38 \% \\
10.49 \% \\
6.99 \% \\
\end{array}$ \\
\hline \multirow{5}{*}{ Qualities } & Participation & & $44.76 \%$ \\
\hline & Dimensionality & $\begin{array}{l}\text { emotional } \\
\text { cognitive } \\
\text { sensorial } \\
\text { social } \\
\text { behavioral }\end{array}$ & $\begin{array}{l}74.13 \% \\
67.83 \% \\
38.46 \% \\
27.27 \% \\
28.67 \%\end{array}$ \\
\hline & Timeflow & $\begin{array}{l}\text { duration } \\
\text { dynamism }\end{array}$ & $\begin{array}{l}13.29 \% \\
16.08 \%\end{array}$ \\
\hline & Valence & $\begin{array}{l}\text { positive } \\
\text { negative } \\
\text { indifferent }\end{array}$ & $\begin{array}{c}22.38 \% \\
17.48 \% \\
2.80 \% \\
\end{array}$ \\
\hline & Ordinariness & $\begin{array}{l}\text { ordinary } \\
\text { extraordinary }\end{array}$ & $\begin{array}{l}16.78 \% \\
19.58 \%\end{array}$ \\
\hline
\end{tabular}


Table 3. Exemplary Research Avenues

Building Block

\begin{tabular}{|c|c|c|}
\hline \multirow{3}{*}{ Touchpoints } & Control & $\begin{array}{l}\text { firm-controlled } \\
\text { non-firm-controlled }\end{array}$ \\
\hline & Nature & $\begin{array}{l}\text { human } \\
\text { physical } \\
\text { digital }\end{array}$ \\
\hline & Stage & $\begin{array}{l}\text { pre-purchase } \\
\text { purchase } \\
\text { post-purchase }\end{array}$ \\
\hline Context & $\begin{array}{l}\text { Individual } \\
\text { Social } \\
\text { Market } \\
\text { Environmental }\end{array}$ & \\
\hline \multirow{5}{*}{ Qualities } & Participation & \\
\hline & Dimensionality & $\begin{array}{l}\text { emotional } \\
\text { cognitive } \\
\text { sensorial } \\
\text { social } \\
\text { behavioral }\end{array}$ \\
\hline & Timeflow & $\begin{array}{l}\text { duration } \\
\text { dynamism }\end{array}$ \\
\hline & Valence & $\begin{array}{l}\text { positive } \\
\text { negative } \\
\text { indifferent }\end{array}$ \\
\hline & Ordinariness & $\begin{array}{l}\text { ordinary } \\
\text { extraordinary }\end{array}$ \\
\hline
\end{tabular}

Sample Research Questions

- How does CX with non-controlled touchpoints affect CX with firm-controlled touchpoint?

- Under what conditions do interactions with non-controlled touchpoints have negative repercussion for brand/firm CX?

- How different is CX in multi-actor settings, such as sharing platforms?

- How do touchpoints of different nature work together?

- What type of touchpoints are most effective early/late in the customer journey?

- Do different touchpoint type paths result in different outcomes?

- How does the increasingly blurred nature of touchpoints impact CX?

- How should brands/firms optimally balance investments and resources across the customer journey stages?

- How do rapid automation and micro-targeting practices along the customer journey impact CX?

- How can contextual data influence CX strategies and inform new business models?

- In what way(s) can brands/firms systematically make use of contextual insights to enhance CX?

- How can brands/firms prioritize the plethora of contextual data? At what level should they best collect, analyze and use contextual data?

- How far can brands/firms go in using contextual data to personalize CX?

- How do major and sudden environmental changes like COVID-19 impact CX(M)?

- How do different levels of participation across the customer journey impact CX?

- How do the various dimensions work in combination?

- How important is each dimension to CX? And how does this differ across situations?

- How may brands/firms best trigger each dimension?

- How might culture moderate the impact or importance of each dimension?

- Are there optional levels of a dimension (e.g., emotional, cognitive, social, sensorial, behavioral) for distinct types of $C X$ ?

- How do the different time - duration, variation, speed, rhythm - aspects impact CX at various stages of the customer journey?

- Does timeflow influence the CX differently depending upon the valence of the experience?

- Can brands/firms influence other aspects of the CX (other qualities dimensions, or specific touchpoints) to make 'negative' experiences - such as health care - less stressful?

- Can firms identify types of experiences that consumers/customers prefer to be indifferent?

- When do customer prefer ordinary experiences?

- When can the often-hyped extraordinary experiences negatively impact value perceptions? 


\section{Table 4. Contexts used in $\mathrm{CX}$ research}

\begin{tabular}{lc} 
Contexts & $\#$ articles $(\mathbf{\%})(\mathbf{n}=\mathbf{2 1 2})^{\mathbf{b}}$ \\
Varied of self-selected $^{\mathrm{a}}$ & $43(20.28 \%)$ \\
Retail & $29(13.68 \%)$ \\
Financial Services & $18(8.49 \%)$ \\
Arts \& Entertainment & $18(8,49 \%)$ \\
Hospitality & $17(8.02 \%)$ \\
Technology \& IT-services & $6(2.83 \%)$ \\
Telecommunications & $6(2.83 \%)$ \\
Healthcare & $5(2.36 \%)$ \\
Travel & $2(0.94 \%)$ \\
Other & $24(11.32 \%)$ \\
N/A & $44(20.75 \%)$ \\
\hline
\end{tabular}

${ }^{\text {a }}$ In self-selected context, the respondents are usually asked to remember a recent CX; whereas varied contexts indicate studies with more than one context (Khamitov et al. 2020).

b While we systematically reviewed 143 articles, the numbers in this table refer to studies within these articles. That is, a single article may contain more than one study. 
Table 5. Methodologies used in $\mathrm{CX}$ research (based on the number of studies within articles)

\begin{tabular}{lc} 
Method & \# articles $(\mathbf{\%}) \mathbf{( n = 2 1 2})^{\mathbf{b}}$ \\
Conceptual & $43(20.28 \%)$ \\
Experiment & $28(13.21 \%)$ \\
Lab experiment (scenario-based) & $11(5.19 \%)$ \\
Online experiment (scenario-based) & $6(2.83 \%)$ \\
Field experiment & $2(0.94 \%)$ \\
Experiment (not specified) & $4(1.89 \%)$ \\
Experiment (other) & $5(2,36 \%)$ \\
Survey & $66(31.13 \%)$ \\
Field survey & $17(8.02 \%)$ \\
Online survey & $22(10.38 \%)$ \\
Lab survey & $11(5.19 \%)$ \\
Mail survey & $1(0,47 \%)$ \\
Survey (not specified) & $7(3.30 \%)$ \\
Survey (other) & $8(3.77 \%)$ \\
Case Study & $17(8.02 \%)$ \\
Ethnography & $8(3.77 \%)$ \\
Other qualitative & $35(16.51 \%)$ \\
Service Design Techniques & $6(2.83 \%)$ \\
Literature Review & $9(4.25 \%)$ \\
\hline
\end{tabular}

${ }^{a}$ combination of various qualitative methods such as interviewing, focus groups, etc.

b While we systematically reviewed 143 articles, the numbers in this table refer to studies within these articles. That is, a single article may contain more than one study. 
Table 6. B2C vs B2C focus in CX research

\begin{tabular}{lc} 
Setting & \# articles $(\mathbf{\%})(\mathbf{n}=\mathbf{2 1 2})^{\mathbf{a}}$ \\
B2C & $195(91.98 \%)$ \\
B2B & $6(2.83 \%)$ \\
B2C \& B2B & $11(5.19 \%)$ \\
\hline
\end{tabular}

${ }^{a}$ While we systematically reviewed 143 articles, the numbers in this table refer to studies within these articles. That is, a single article may contain more than one study. 
Table 7. Country Focus in CX research

\begin{tabular}{lc} 
Country & \# articles $(\mathbf{\%}) \mathbf{( n = 2 1 2})^{\mathbf{a}}$ \\
USA & $52(24.53 \%)$ \\
Multi-Country & $18(8.49 \%)$ \\
Portugal & $14(6.60 \%)$ \\
UK & $12(5.66 \%)$ \\
India & $9(4.25 \%)$ \\
Australia & $4(1.89 \%)$ \\
France & $4(1.89 \%)$ \\
Kuwait & $4(1.89 \%)$ \\
Sweden & $4(1.89 \%)$ \\
Canada & $3(1.42 \%)$ \\
Finland & $3(1.42 \%)$ \\
Japan & $3(1.42 \%)$ \\
China & $1(0.47 \%)$ \\
Egypt & $1(0.47 \%)$ \\
Germany & $1(0.47 \%)$ \\
Malaysia & $1(0.47 \%)$ \\
Norway & $1(0.47 \%)$ \\
Spain & $1(0.47 \%)$ \\
Not specified & $24(11.32 \%)$ \\
N/A & $52(24.53 \%)$ \\
\hline
\end{tabular}

${ }^{a}$ While we systematically reviewed 143 articles, the numbers in this table refer to studies within these articles. That is, a single article may contain more than one study. 
Table 8. TCQ Checklist for CX Management

\section{Audit}

(1) Streamline Touchpoint Overview

- List distinct touchpoints along the customer journey

- What is their nature?

- What level of control does the brand/firm have?

- At what stage do they occur (i.e., what goal is the customer trying to achieve?)?

- Assess touchpoint connectivity and consistency

- How easy is it to move from one touchpoint to another?

- Does CX match across touchpoints?

(2) Recognize Context

- What contextual influences are at play?

- To what extent are touchpoints context-sensitive by design?

- Does the brand/firm have data to capture/assess contextual influences?

(3) Assess all Delivered Qualities

- What qualities are experienced at the various touchpoints?

- To what extent do touchpoints create value for the customer? In what way(s)?

(4) Evaluate, Benchmark and Move to Action

- What strengths, weaknesses, opportunities and threats exist in the current CX?

- How does our CX compare to that of our competitors?

- Where do we need to fix, improve or remove touchpoints to improve the CX?

- Outline current pain points and improvement opportunities that can be characterized through existing TCQ combinations and make operational changes

\section{Innovation \& Design}

(1) Determine Desired Experience Qualities

- What qualities are customers looking for/expecting at the various touchpoints?

- To what extent is each quality - level of participation, multidimensionality, timeflow, valence, ordinariness - potentially important (or unimportant) along the customer journey?

(2) Assess the Need for Contextual Information

- What contextual data can and/or should be collected to enhance touchpoints so that they allow specific qualities to occur?

- How can be best integrate this type of information into the brand/firm's touchpoints?

(3) Determine the Needed Touchpoint Constellation

- What type of touchpoint constellation is best to promote sought-after qualities?

- To what extent do existing touchpoints need to be adapted or removed? Are new touchpoints required?

(4) Move to Action: Experiment, Assess, Iterate

- What are the most likely opportunities to innovate and differentiate CX?

- To what extent do adapted touchpoints enhance CX? 
Figure 1: Search strategy, sampling frame and selection process

Search string: TS=("customer experience" OR "consumption experience" OR "service experience" OR "consumer experience" OR "customer journey" OR "consumer journey" OR "experiential marketing")

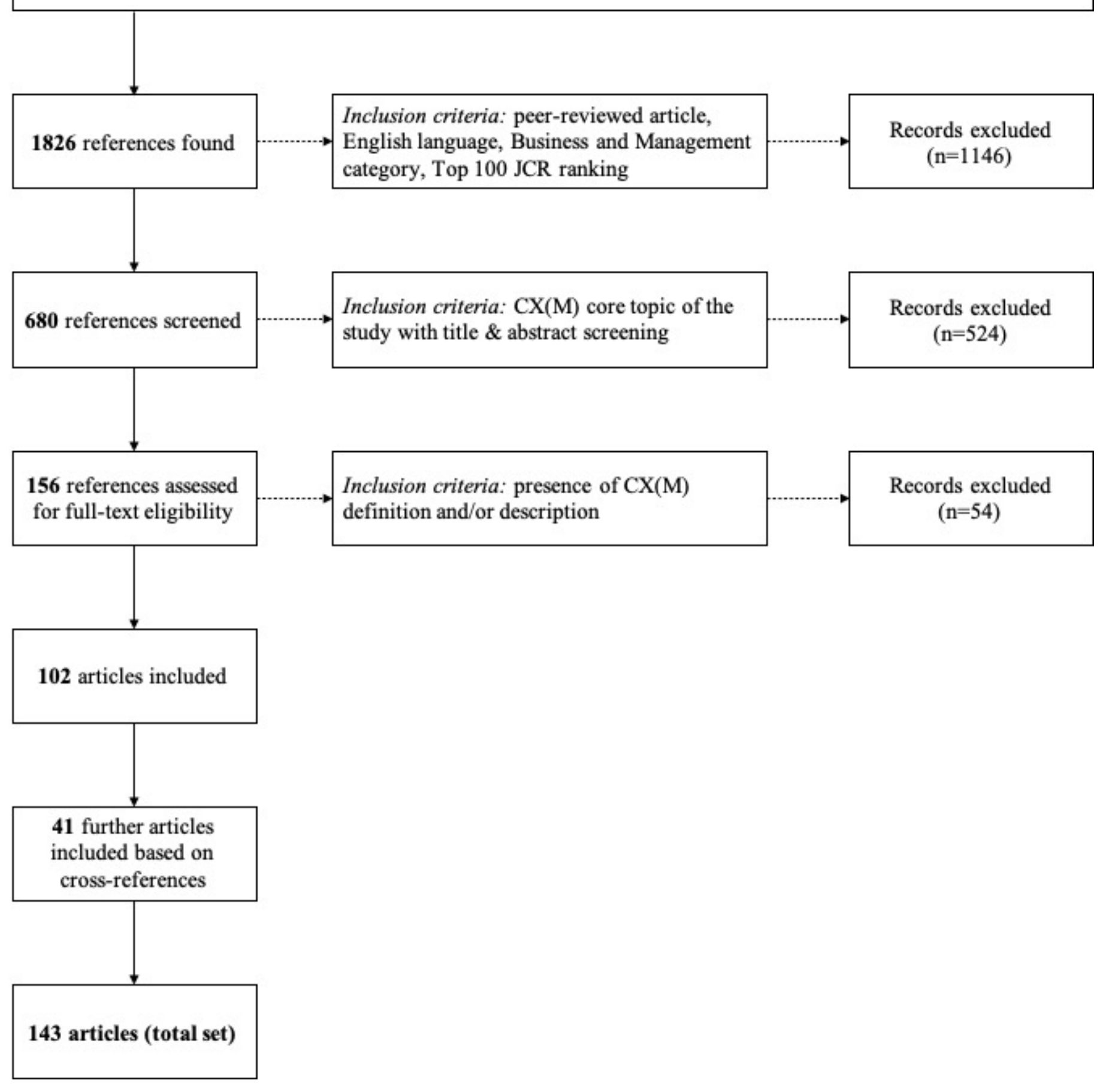




\section{Figure 2. TCQ Nomenclature}

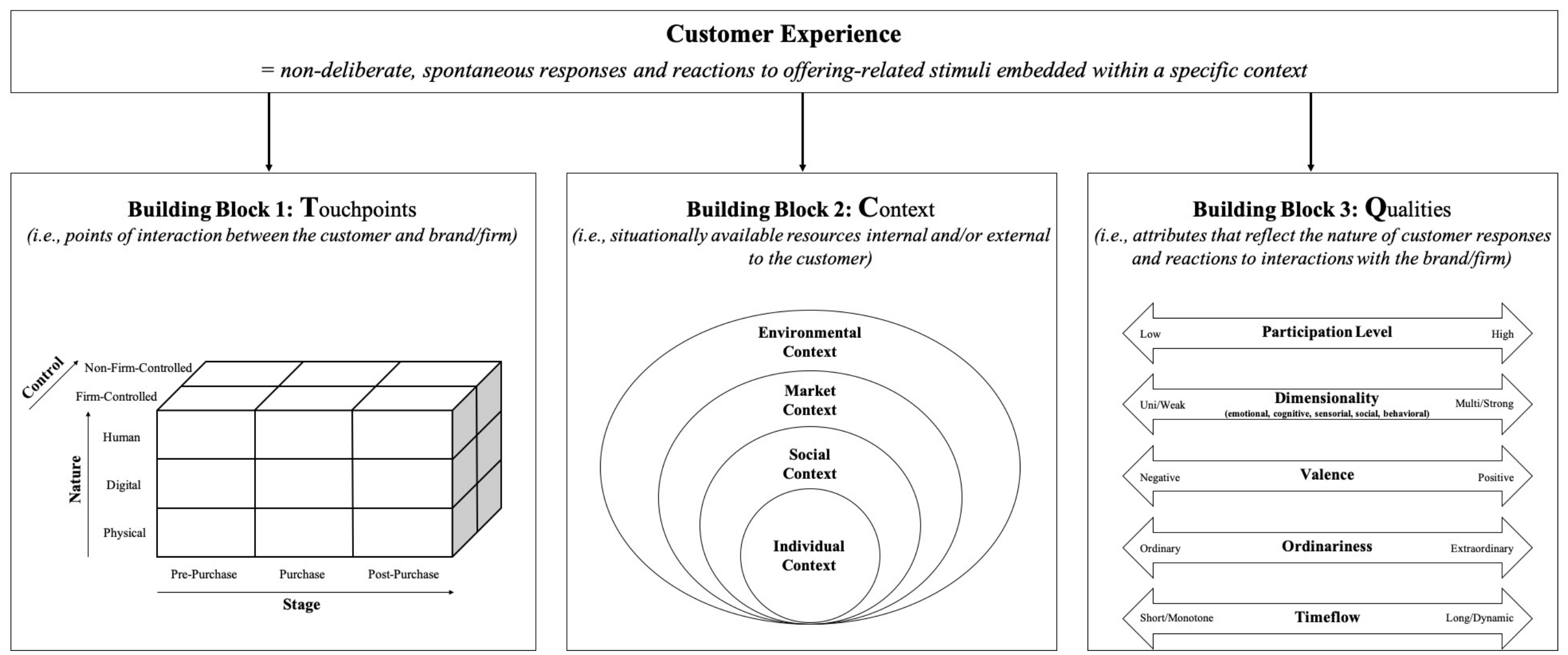




\section{$\underline{\text { References }}$}

Aguirre, Elizabeth, Dominik Mahr, Dhruv Grewal, Ko de Ruyter, and Martin Wetzels (2015), "Unraveling The Personalization Paradox: The Effect of Information Collection and Trust-building Strategies on Online Advertisement Effectiveness," Journal of Retailing, 91 (1), 34-49.

Akaka, Melissa Archpru, Stephen L. Vargo, and Hope Jensen Schau (2015), "The Context of Experience," Journal of Service Management, 26 (2), 206-23.

Åkesson, Maria, Bo Edvardsson, and Bârd Tronvoll (2014), "Customer Experience from a Self-Service System Perspective,” Journal of Service Management, 25 (5), 677-98.

Almquist, Eric, John Senior, and Nicolas Bloch (2016), “The Elements of Value. Measuring and delivering - what consumers really want," Harvard Business Review, 94 (9), 46-53.

Andrade, Eduardo B. and Joel B. Cohen (2007), "On The Consumption of Negative Feelings," Journal of Consumer Research, 34 (3), 283-300.

André, Quentin, Ziv Carmon, Klaus Wertenbroch, Alia Crum, Douglas Frank, William Goldstein, Joel Huber, Leaf van Boven, Bernd Weber, and Haiyang Yang (2018), "Consumer Choice and Autonomy in the Age of Artificial Intelligence and Big Data," Customer Needs and Solutions, 5 (1), 28-37.

Arnould, Eric J. and Linda L. Price (1993), "River Magic - Extraordinary Experience and the Extended Service Encounter," Journal of Consumer Research, 20 (1), 24-45.

Becker, Larissa and Elina Jaakkola (2020) "Customer Experience: Fundamental Premises and Implications for Research," Journal of the Academy of Marketing Science, forthcoming.

Belk, Russell W. (1975), "Situational Variables and Consumer Behavior," Journal of Consumer Research, 2 (3), 157-64.

Berry, Leonard L., Lewis P. Carbone, and Stephan H. Haeckel (2002), "Managing The Total Customer Experience," MIT Sloan Management Review, 43 (3), 85-89.

Bettencourt, Lance A., Robert F. Lusch, and Stephen L. Vargo (2014), "A Service Lens on Value Creation: Marketing's Role in Achieving Strategic Advantage," California Management Review, 57 (1), 44-66.

Bitner, Mary Jo, Amy L. Ostrom, and Felicia N. Morgan (2008), "Service Blueprinting: A Practical Technique for Service Innovation," California Management Review, 50 (3), 66-94.

Bleier, Alex, Arne De Keyser, and Katrien Verleye (2018), “Customer Engagement Through Personalization and Customization," in Customer Engagement Marketing, R. W. Palmatier, V. Kumar, and C. M. Harmeling, eds., Palgrave Macmillan, 75-94.

Bleier, Alexander, Colleen M. Harmeling, and Robert W. Palmatier (2019), "Creating Effective Online Customer Experiences," Journal of Marketing, 83 (2), 98-119.

Bolton, Ruth N., Janet R McColl-Kennedy, L. Cheung, A.S. Gallan, Chiara Orsingher, Lars Witell, and Mohamed Zaki (2018), "Customer Experience Challenges: Bringing Together Digital, Physical and Social Realms," Journal of Service Management, 29 (5), 776-808.

Bolton, Ruth N., Anders Gustafsson, Jannet McColl-Kennedy, Nancy J. Sirianni, and David K. Tse (2014), "Small Details That Make Big Differences - A Radical Approach to Consumption Experience as a Firm's Differentiating Strategy," Journal of Service 
Management, 25 (2), 253-74.

Brakus, J. Jôsko, Bernd H. Schmitt, and Lia Zarantonello (2009), "Brand Experience: What Is

It? How Is It Measured? Does It Affect Loyalty?," Journal of Marketing, 73 (3), 52-68.

Brocato, E. Deanne, Clay M. Voorhees, and Julie Baker (2012), "Understanding the Influence of Cues from Other Customers in the Service Experience: A Scale Development and Validation," Journal of Retailing, 88 (3), 384-98.

Carbone, Lewis P. and Stephan H. Haeckel (1994), "Engineering Customer Experiences," Marketing Management, 3 (3), 8-19.

Carù, Antonella and Bernard Cova (2015), "Co-creating The Collective Service Experience," Journal of Service Management, 26 (2), 276-94.

Chandler, Jennifer D. and Robert F. Lusch (2015), "Service Systems: A Broadened

Framework and Research Agenda on Value Propositions, Engagement, and Service

Experience," Journal of Service Research, 18 (1), 6-22.

Chandler, Jennifer D. and Stephen L. Vargo (2011), "Contextualization and Value-in-

Context: How Context Frames Exchange," Marketing Theory, 11 (1), 35-49.

Davey, Neil (2019), "Why Are CMOs Losing Interest in Customer Experience?," (accessed

August 6, 2019), [available at https://www.mycustomer.com/marketing/strategy/why-arecmos-losing-interest-in-customer-experience]

De Keyser, Arne, Sarah Köcher, Linda Alkire (née Nasr), Cédric Verbeeck, and Jay

Kandampully (2019), "Frontline Technology Infusion: Conceptual Archetypes and a

Future Research Agenda,” Journal of Service Management, 30 (1), 156-83.

, Katherine N. Lemon, Philipp Klaus, and Timothy L. Keiningham (2015), “A

Framework for Understanding and Managing the CX," Marketing Science Institute

Working Paper Series 2015, Report No. 15-121, Marketing Science Institute,

Cambridge, MA.

Dose, David B., Gianfranco Walsh, Sharon E. Beatty, and Ralf Elsner (2019), "Unintended

Reward Costs: The Effectiveness of Customer Referral Reward Programs for Innovative

Products and Services," Journal of the Academy of Marketing Science, 47 (3), 438-59.

Durrande-Moreau, Agnès and Jean-Claude Usunier (1999), "Time Styles and the Waiting

Experience: An Exploratory Study," Journal of Service Research, 2 (2), 173-86.

Eckhardt, Giana M., Mark B. Houston, Baojun Jiang, Cait Lamberton, Aric Rindfleisch, and

Georgios Zervas (2019), "Marketing in the Sharing Economy," Journal of Marketing, 83

(5), 5-27.

Forrester Research (2019), "Light on The Horizon: The State of Customer Experience Quality," (accessed June 14, 2019), [available at https://go.forrester.com/cx-index-2019/] Gahler, Markus, Jan F. Klein, and Michael Paul (2019), "Measuring Customer Experiences :

A Text-Based and Pictorial Scale," Marketing Science Institute Working Paper Series 2019, Report No. 19-119, Marketing Science Institute, Cambridge, MA.

Gao, Lily Xuehui, Iguácel Melero-Polo, and F. Javier Sese (2020), “Customer Equity Drivers, Customer Experience Quality, and Customer Profitability in Banking Services : The Moderating Role of Social Influence," Journal of Service Research, forthcoming.

Gentile, Chiara, Nicola Spiller, and Giuliano Noci (2007), "How to Sustain the Customer

Experience: An Overview of Experience Components that Co-create Value With the

Customer," European Management Journal, 25 (5), 395-410. 
Michael Levy, and V. Kumar (2009), "Customer Experience Management in Retailing: An Organizing Framework," Journal of Retailing, 85 (1), 1-14.

Goodwin, Tom (2015), "The Battle is for the Customer Interface," Tech Crunch. (accessed January 10, 2020), [available at https://techcrunch.com/2015/03/03/in-the-ageof-disintermediation-the-battle-is-all-for-the-customer-interface/.]

Grove, Stephen J. and Raymond P. Fisk (1997), "The Impact of Other Customers on Service Experiences: A Critical Incident Examination of 'Getting Along,'” Journal of Retailing, $73(1), 63-85$.

Hamilton, Rebecca (2016), "Consumer-Based Strategy: Using Multiple Methods to Generate Consumer Insights for Strategy," Journal of the Academy of Marketing Science, 47 (2), 281-285.

Harvard Business Review Analytic Services (2017), "Closing the Customer Experience Gap: How IT and Business Can Partner to Transform Customer Experiences," (accessed June 14, 2019), [available at https://hbr.org/sponsored/2017/08/closing-the-customerexperience-gap]

Haselton, Todd (2020), “Apple's New Connected Gyms Program Gives You Benefits for Working Out with Apple Watch,” CNBC. (accessed January 20, 2020), [available at https://www.cnbc.com/2020/01/23/apple-watch-connected-gyms-announced-in-us.html.]

Hazée, Simon, Cécile Delcourt, and Yves Van Vaerenbergh (2017), "Burdens of Access: Understanding Customer Barriers and Barrier-Attenuating Practices in Access-Based Services," Journal of Service Research, 20 (4), 441-56.

Helkkula, Anu (2011), "Characterising the Concept of Service Experience," Journal of Service Management, 22 (3), 367-89.

, Carol Kelleher, and Minna Pihlstrom (2012a), "Practices and Experiences:

Challenges and Opportunities for Value Research," Journal of Service Management, 23 (4), 554-70.

$\longrightarrow$ - — for Service Researchers and Managers,” Journal of Service Research, 15 (1), 59-75.

Hirschman, Elizabeth C. and Morris B. Holbrook (1982), "Hedonic Consumption - Emerging Concepts, Methods and Propositions," Journal of Marketing, 46 (3), 92-101.

Hoffman, Donna L. and Thomas P. Novak (2018), "Consumer and Object Experience in the Internet of Things: An Assemblage Theory Approach," Journal of Consumer Research, 44 (6), 1178-1204.

Holbrook, Morris B. and Elizabeth C. Hirschman (1982), “The Experiential Aspects of Consumption - Consumer Fantasies, Feelings, and Fun," Journal of Consumer Research, 9 (2), 132-40.

Homburg, Cristian, Danijel Jozíc, and Christina Kuehnl (2017), "Customer Experience Management: Toward Implementing An Evolving Marketing Concept," Journal of the Academy of Marketing Science, 45 (3), 377-401.

Houston, Mark (2016), "Is "Strategy" a Dirty Word?," Journal of the Academy of Marketing Science, 44 (5), 557-561.

Hughes, Christian, Vanitha Swaminathan, and Gillian Brooks (2019), "Driving Brand Engagement Through Online Social Influencers : An Empirical Investigation of Sponsored Blogging Campaigns," Journal of Marketing, 83 (5), 78-96. 
Hui, Michael K. and John E. G. Bateson (1991), "Perceived Control and the Effects of Crowding and Consumer Choice on the Service Experience Stable," Journal of Consumer Research, 18 (2), 174-84.

Jaakkola, Elina, Anu Helkkula, and Leena Aarikka-Stenroos (2015), "Service Experience CoCreation: Conceptualization, Implications, and Future Research Directions," Journal of Service Management, 26 (2), 182-205.

Jain, Rajnish, Jayesh Aagja, and Shilpa Bagdare (2017), "Customer Experience - A Review and Research Agenda," Journal of Service Theory and Practice, 27 (3), 642-662.

Kabadayi, Sertan, Faizan Ali, Hyeyoon Choi, Herm Joosten, and Can Lu (2019), "Smart Service Experience in Hospitality and Tourism Services: A Conceptualization and Future Research Agenda," Journal of Service Management, 30 (3), 326-348.

Kannan, P. K., Werner Reinartz, and Peter C. Verhoef (2016), "The Path to Purchase and Attribution Modeling: Introduction to the Special Section," International Journal of Research in Marketing, 33 (3), 449-56.

Keiningham, Timothy L., Lerzan Aksoy, Helen L. Bruce, Fabienne Cadet, Natasha Clennell, Ian R. Hodgkinson, and Treasa Kearney (2020), "Customer Experience Driven Business Model Innovation," Journal of Business Research, forthcoming.

Khamitov, Mansur, Yany Grégoire, and Ansu Suri (2020), “A Systematic Review of Brand Transgression, Service Failure Recovery and Product Harm Crisis: Integration and Guiding Insights," Journal of the Academy of Marketing Science, forthcoming.

Klaus, Philipp (2013), "The Case of Amazon.com: Towards a Conceptual Framework of Online Customer Service Experience (OCSE) Using the Emerging Consensus Technique (ECT)," Journal of Services Marketing, 27 (6), 443-57.

(2019), "Viewpoint: Converying Managerial Relevance into Service Research," Journal of Services Marketing, 33 (1), 104-11.

_ and Stan Maklan (2012), "EXQ: A Multiple-Item Scale for Assessing Service Experience," Journal of Service Management, 23 (1), 5-33.

Kranzbühler, Anne-Madeleine, Mirella H. P. Kleijnen, Robert E. Morgan, and Marije Teerling (2018), "The Multilevel Nature of Customer Experience Research : An Integrative Review and Research Agenda," International Journal of Management Reviews, 20 (2), 433-56.

— Mirella H. P. Kleijnen, and Peeter W. J. Verlegh (2019), "Outsourcing the Pain , Keeping the Pleasure: Effects of Outsourced Touchpoints in the Customer Journey," Journal of the Academy of Marketing Science, 47 (2), 308-27.

Kuehnl, Christina, Jozic, Danijel, and Christian Homburg (2019), "Effective Customer Journey Design: Consumers' Conception, Measurement, and Consequences," Journal of the Academy of Marketing Science, 47 (3), 551-568.

Kumar, V., Nita Umashankar, Kihyun H Kim, and Yashoda Bhagwat (2014), “Assessing the Influence of Economic and Customer Experience Factors on Service Purchase Behaviors," Marketing Science, 33 (5), 673-92.

Lamberton, Cait and Andrew T. Stephen (2016), “A Thematic Exploration of Digital, Social Media, and Mobile Marketing Research's Evolution from 2000 to 2015 and an Agenda for Future Research," Journal of Marketing, 80 (6), 146-72. 
Latib, Mohamed (2018), "Customer Experience Will Be a Fad Without a Better Business Case," (accessed June 14, 2019), [available at http://customerthink.com/customer-experiencewill-be-a-fad-without-a-better-business-case/]

LaTour, Kathryn A. and Lewis P. Carbone (2014), "Sticktion: Assessing Memory for the Customer Experience," Cornell Hospitality Quarterly, 55 (February), 342-53.

Lemke, Fred, Moira Clark, and Hugh Wilson (2011), "Customer Experience Quality: An Exploration in Business and Consumer Contexts Using Repertory Grid Technique," Journal of the Academy of Marketing Science, 39 (6), 846-69.

Lemon, Katherine N. (2016), "The Art of Creating Attractive Consumer Experiences at the Right Time : Skills Marketers Will Need to Survive and Thrive," GfK Marketing Intelligence Review, 8 (2), 44-49.

and Peter C. Verhoef (2016), "Understanding Customer Experience and the Customer Journey," Journal of Marketing, 80 (6), 69-96.

Lipkin, Michaela (2016), "Customer Experience Formation in Today's Service Landscape," Journal of Service Management, 27 (5), 678-703.

Luo, Xueming, Siliang Tong, Zheng Fang, and Zhe Qu (2019), "Frontiers: Machines vs Humans: The Impact of Artificial Intelligence Chatbot Disclosure on Customer Purchases, " Marketing Science, 38(6), 937-947.

Macdonald, Emma K., Hugh N. Wilson, and Umut Konus (2012), "Better Customer Insightin Real Time," Harvard Business Review, 90 (9), 102-8.

MacInnis, Deborah J. (2011), "A Framework for Conceptual Contributions in Marketing," Journal of Marketing, 75 (4), 136-54.

Mahr, Dominik, Susan Stead, and Gaby Odekerken-schröder (2019), "Making Sense of Customer Service Experiences : A Text Mining Review," Journal of Services Marketing, 33 (1), 88-103.

Maklan, Stan, Paolo Antonetti, and Steve Whitty (2017), “A Better Way to Manage Customer Experience: Lessons from the Royal Bank of Scotland," California Mangement Review, 59 (2), 92-115.

McColl-Kennedy, Janet R., Anders Gustafsson, Elina Jaakkola, Philipp Klaus, Zoe Radnor, Helen Perks, and Margareta Friman (2015), "Fresh Perspectives on Customer Experience," Journal of Services Marketing, 29 (6/7), 430-35.

_- Stephen L. Vargo, Tracey S. Dagger, Jillian C. Sweeney, and Yasmin van Kasteren (2012), "Health Care Customer Value Cocreation Practice Styles," Journal of Service Research, 15 (4), 370-89.

—- Mohamed Zaki, Katherine N. Lemon, Florian Urmetzer, and Andy Neely (2019), “Gaining Customer Experience Insights That Matter," Journal of Service Research, 22 (1), 8-26.

Mclean, Graeme, Khalid Al-Nabhani, and Alan Wilson (2018), "Developing a Mobile Applications Customer Experience Model (MACE ) - Implications for Retailers," Journal of Business Research, 85 (January), 325-36.

Mele, Christina, Jacqueline Pels, and Kaj Storbacka (2015), “A Holistic Market Conceptualization," Journal of the Academy of Marketing Science, 43 (1), 100-114. Mericle, Julia (2018), "Gridwise Looks to Expand to All Major U.S. Cities," Pittsburgh Business Times. (accessed January 15, 2020), [available at 
https://www.bizjournals.com/pittsburgh/news/2018/10/09/gridwise-looks-to-expand-toall-major-u-s-cities.html.]

Meyer, Christopher and Andre Schwager (2007), "Understanding Customer Experience," Harvard Business Review, 85 (2), 117-26.

Moeller, S., Ciuchita, R., Mahr, D., Odekerken-Schröder, G. and Fassnacht, M. (2013), "Uncovering Collaborative Value Creation: Patterns and Establishing Corresponding Customer Roles", Journal of Service Research, 16 (4), 471-487.

Morgan, Blake (2018), "Why Many Customer Experience Programs Are Still Failing to Deliver," Forbes. (accessed June 20, 2019), [available at https://www.forbes.com/sites/blakemorgan/2018/07/30/why-many-customer-experienceprograms-are-still-failing-to-deliver/\#569edc9e35d2.]

MSI (Marketing Science Institute) (2010), 2010-2012 Research Priorities. Cambridge, MA: Marketing Science Institute.

(2012), 2012-2014 Research Priorities. Cambridge, MA: Marketing Science Institute. (2014), 2014-2016 Research Priorities. Cambridge, MA: Marketing Science Institute. (2016), Research Priorities 2016-2018. Cambridge, MA: Marketing Science Institute. (2018), Research Priorities 2018-2020. Cambridge, MA: Marketing Science Institute.

Novak, Thomas P., Donna L. Hoffman, and Yiu-Fai Yung (2000), "Measuring The Customer Experience in Online Environments: A Structural Modeling Approach," Marketing Science, 19 (1), 22-42.

Ordenes, Francisco Villarroel and Shunyuan Zhang (2019), "From Words to Pixels: Text and Image Mining Methods for Service Research," Journal of Service Management, 30 (5), 593-620.

Patricio, Lia, Raymond P. Fisk, and João Falcão e Cunha Cunha (2008), "Designing MultiInterface Service Experiences - The Service Experience Blueprint," Journal of Service Research, 10 (4), 318-34.

Payne, Adrian F., Kaj Storbacka, Pennie Frow, and Simon Knox (2009), "Co-Creating Brands: Diagnosing and Designing the Relationship Experience," Journal of Business Research, 62 (3), 379-89.

Pine, B. J. and J. H. Gilmore (1998), "Welcome to the experience economy," Harvard Business Review, 76 (4), 97-105.

Ponsignon, Frederic, Francois Durrieu, and Tatiana Bouzdine-Chameeva (2017), "Customer Experience Design: A Case Study in the Cultural Sector," Journal of Service Management, 28 (4), 763-87.

Puccinelli, Nancy M., Ronald C. Goodstein, Dhruv Grewal, Robert Price, Priya Raghubir, and David Stewart (2009), "Customer Experience Management in Retailing: Understanding the Buying Process," Journal of Retailing, 85 (1), 15-30.

Rawson, Alex, Ewan Duncan, and Conor Jones (2013), "Touchpoints Matter, But It's the Full Journey That Really Counts," Harvard Business Review, 91 (9), 90-98.

Robinson, Stacey G., Chiara Orsingher, Linda Alkire (née Nasr), Arne De Keyser, Michael Giebelhausen, K. Nadia Papamichail, Poja Shams, and Mohamed Sobhy Temerak (2020), "Frontline Encounters of the AI Kind: An Evolved Service Encounter Framework," Journal of Business Research, forthcoming.

Rose, Susan, Moira Clark, Phillip Samouel, and Neil Hair (2012), "Online Customer 
Experience in e-Retailing: An Empirical Model of Antecedents and Outcomes," Journal of Retailing, 88 (2), 308-22.

, Neil Hair, and Moira Clark (2011), "Online Customer Experience: A Review of the Business-to-Consumer Online Purchase Context," International Journal of Management Reviews, 13 (1), 24-39.'

Rosenbaum, Mark S., Mauricio Losada Otalora and Germán Contreras Ramírez (2017), "How

To Create a Realistic Customer Journey Map," Business Horizons, 60 (1), 143-50.

Roy, Subhadip, S. Sreejesh, and Sandhya Bhatia (2019), "Service Quality Versus Service

Experience: An Empirical Examination of the Consequential Effects in B2B Services,"

Industrial Marketing Management, 82, 52-69.

Saldaña, Johnny (2014), "Coding and Analyis Strategies," in The Oxford Handbook of

Qualitative Research, P. Leavy, ed., Oxford University, 581-605.

Sändstrom, Sara, Bo Edvardsson, Per Kristensson, and Peter Magnusson (2008), "Value in

Use Through Service Experience," Managing Service Quality, 18 (2), 112-26.

Schmitt, Bernd H. (1999), Experiential Marketing, New York, NY: Free Press.

- (2010), "Experience Marketing: Concepts, Frameworks and Consumer Insights,"

Foundations and Trends in Marketing, 5 (2), 55-112.

_ _ J. Jôsko Brakus, and Lio Zarantonello (2015), "From Experiential Psychology to

Consumer Experience,” Journal of Consumer Psychology, 25 (1), 166-71.

Schouten, John W., James H. McAlexander, and Harold F. Koenig (2007), “Transcendent

Customer Experience and Brand Community," Journal of the Academy of Marketing

Science, 35 (3), 357-68.

Scott, Rebecca, Julien Cayla, and Bernard Cova (2017), "Selling Pain to the Saturated Self,"

Journal of Consumer Research, 44, 22-43.

Shavitt, Sharon and Aaron J. Barnes (2019), "Cross-Cultural Consumer Psychology,"

Consumer Psychology Review, 2 (1), 70-84.

- - (2020), "Culture and the Consumer Journey," Journal of Retailing,

forthcoming.

Siggelkow, Nicolaj and Christian Terwiesch (2019), "The Age of Continuous Connection," Harvard Business Review, 97 (3), 63-73.

Singh, Jagdip, Michael K. Brady, Todd Arnold, and Tom Brown (2017), "The Emergent Field of Organizational Frontlines," Journal of Service Research, 20 (1), 3-11.

Tax, Stephen S., David McCutcheon, and Ian F. Wilkinson (2013), "The Service Delivery Network (SDN): A Customer-Centric Perspective of the Customer Journey," Journal of Service Research, 16 (4), 454-70.

Thomadsen, Raphael, Robert P. Rooderkerk, On Amir, Neeraj Arora, Bryan Bollinger,

Karsten Hansen, Leslie John, Wendy Liu, Aner Sela, Vishal Singh, K. Sudhir, and Wendy Wood (2018), "How Context Affects Choice," Customer Needs and Solutions, 5 (1-2), 3-14.

Thompson, Bob (2018), “An Inconvenient Truth: 93\% of Customer Experience Initiatives are Failing," (accessed June 14, 2019), [available at http://customerthink.com/an-inconvenienttruth-93-of-customer-experience-initiatives-are-failing/].

Thompson, Craig J., William B. Locander, and Howard R. Pollio (1989), "Putting Consumer

Experience Back into Consumer Research - the Philosophy and Method of Existential 
Phenomenology," Journal of Consumer Research, 16 (2), 133-46.

Todri, Vilma, Anindya Ghose, and Param Vir Singh (2019), "Trade-offs in Online

Advertising: Advertising Effectiveness and Annoyance Dynamics across the Purchase Funnel," Marketing Science Institute Working Paper Series 2019, Report No. 19-126, Marketing Science Institute, Cambridge, MA.

Tumbat, Gülnur and Russell W. Belk (2011), "Marketplace Tensions in Extraordinary Experiences," Journal of Consumer Research, 38 (1), 42-61.

Verhoef, Peter C., Katherine N. Lemon, A. Parasuraman, Anne Roggeveen, Michael Tsiros, and Leonard A. Schlesinger (2009), "Customer Experience Creation: Determinants, Dynamics and Management Strategies," Journal of Retailing, 85 (1), 31-41.

Verhulst, Nanouk, Arne De Keyser, Anders Gustafsson, Poja Shams, and Yves Van Vaerenbergh (2019), "Neuroscience in Service Research: An Overview and Discussion of its Possibilities," Journal of Service Management, 30 (5), 621-649.

Verleye, Katrien (2015), “The Co-Creation Experience From The Customer Perspective: Its Measurement and Determinants," Journal of Service Management, 26 (2), 321-42. (2019), "Designing, Writing-up and Reviewing Case Study Research: An Equifinality Perspective," Journal of Service Management, 30 (5), 549-576.

Voorhees, Clay M., Paul W. Fombelle, Yany Gregoire, Sterling Bone, Anders Gustafsson, Rui Sousa, and Travis Walkowiak (2017), "Service Encounters, Experiences and the Customer Journey : Defining the Field and a Call to Expand our Lens," Journal of Business Research, 79, 269-80.

Wirtz, Jochen, Kevin Fam Fun So, Makarand Amrish Mody, Stephanie Q. Liu, and Haeeun Helen Chun (2019), "Platforms in the Peer-to-Peer Sharing Economy," Journal of Service Management, 30 (4), 452-483.

Woermann, Niklas and Joonas Rokka (2015), "Timeflow: How Consumption Practices Shape Consumers' Temporal Experiences," Journal of Consumer Research, 41 (6), 1486-1508. Zolkiewski, Judy, Victoria Story, Jamie Burton, Paul Chan, Andre Gomes, Philippa Hunterjones, Lisa O Malley, Linda D. Peters, Chris Raddats, and William Robinson (2017), "Strategic B2B Customer Experience Management: The Importance of Outcomes-Based Measures," Journal of Services Marketing, 31 (2), 172-84. 


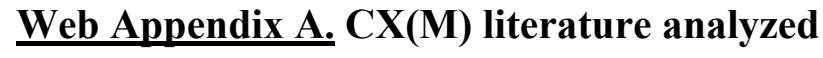

1. Akaka, Melissa Archpru, Stephen L. Vargo, and Hope Jensen Schau (2015), "The Context of Experience," Journal of Service Management, 26 (2), 206-23.

2. Åkesson, Maria, Bo Edvardsson, and Bârd Tronvoll (2014), "Customer Experience from a Self-Service System Perspective,” Journal of Service Management, 25 (5), 67798.

3. Albrecht, Carmen Maria, Stefan Hattula, Torsten Bornemann, and Wayne D. Hoyer (2016), "Customer Response to Interactional Service Experience: The Role of Interaction Environment," Journal of Service Management, 27 (5), 704-29.

4. Al-Wugayan, Adel A.A. (2019), "Relationship Versus Customer Experience Quality as Determinants of Relationship Quality and Relational Outomes for Kuwaiti Retail Banks," International Journal of Bank Marketing, 37 (5), 1234-1252.

5. Anderson, Sidney T. and Jeffery S. Smith (2016), "An Empirical Examination of the Impact of Tri-Dyadic Fit on the Service Experience," Journal of Service Management, 27 (3), 299-319.

6. Arnould, Eric J. and Linda L. Price (1993), "River Magic - Extraordinary Experience and the Extended Service Encounter," Journal of Consumer Research, 20 (1), 24-45.

7. Baron, Steven and Kim Harris (2010), "Toward An Understanding of Consumer Perspectives on Experiences," Journal of Services Marketing, 24 (7), 518-31.

8. Becker, Larissa and Elina Jaakkola (2020) "Customer Experience: Fundamental Premises and Implications for Research," Journal of the Academy of Marketing Science, forthcoming.

9. Beltagui, Ahmad, Marina Candi, and Johann C.K.H. Riedel (2016), "Setting the Stage for Service Experience: Design Strategies for Functional Services," Journal of Service Management, 27 (5), 751-72.

10. Berry, Leonard L., Lewis P. Carbone, and Stephan H. Haeckel (2002), "Managing the Total Customer Experience,” MIT Sloan Management Review, 43 (3), 85-89.

11. __ Eileen A. Wall, and Lewis P. Carbone (2006), "Service Clues and Customer Assessment of the Service Experience: Lessons from Marketing," Academy of Management Perspectives, 20 (2), 43-57.

12. Bhattacharjee, Amit and Cassie Mogilner (2014), "Happiness from Ordinary and Extraordinary Experiences,” Journal of Consumer Research, 41 (1), 1-17.

13. Bleier, Alexander, Colleen M. Harmeling, and Robert W. Palmatier (2019), "Creating Effective Online Customer Experiences,” Journal of Marketing, 83 (2), 98-119.

14. Bolton, Ruth N., Janet R. McColl-Kennedy, L. Cheung, Allan S. Gallan, Chiara Orsingher, Lars Witell, and Mohamed Zaki (2018), "Customer Experience Challenges: Bringing Together Digital, Physical and Social Realms," Journal of Service Management, 29 (5), 776-808.

15. Bolton, Ruth N., Anders Gustafsson, Jannet McColl-Kennedy, Nancy J. Sirianni, and David K. Tse (2014), "Small Details That Make Big Differences - A Radical Approach to Consumption Experience as a Firm's Differentiating Strategy," Journal of Service Management, 25 (2), 253-74.

16. Brakus, J. Jôsko, Bernd H. Schmitt, and Lia Zarantonello (2009), "Brand Experience: 
What Is It? How Is It Measured? Does It Affect Loyalty?," Journal of Marketing, 73 (3), 52-68.

17. Brocato, E. Deanne, Clay M. Voorhees, and Julie Baker (2012), "Understanding the Influence of Cues from Other Customers in the Service Experience: A Scale Development and Validation," Journal of Retailing, 88 (3), 384-98.

18. Bustamante, Juan Carlos and Natalia Rubio (2017), "Measuring Customer Experience in Physical Retail Environments," Journal of Service Management, 28 (5), 884-913.

19. Carbone, Lewis P. and Stephan H. Haeckel (1994), "Engineering Customer Experiences," Marketing Management, 3 (3), 8-19.

20. Carù, Antonella and Bernard Cova (2003), "Revisiting Consumption Experience: A More Humble but Complete View of the Concept," Marketing Theory, 3 (2), 267-86.

21. - (2015), "Co-Creating The Collective Service Experience," Journal of Service Management, 26 (2), 276-94.

22. Chandler, Jennifer D. and Robert F. Lusch (2015), "Service Systems: A Broadened Framework and Research Agenda on Value Propositions, Engagement, and Service Experience," Journal of Service Research, 18 (1), 6-22.

23. Collier, Joel E., Donald C. Barnes, Alexandra K. Abney, and Mark J. Pelletier (2018), "Idiosyncratic Service Experiences : When Customers Desire the Extraordinary in a Service Encounter," Journal of Business Research, 84, 150-61.

24. De Keyser, Arne, Katherine N. Lemon, Philipp Klaus, and Timothy L. Keiningham (2015), “A Framework for Understanding and Managing the CX," Marketing Science Institute Working Paper Series 2015, Report No. 15-121, Marketing Science Institute, Cambridge, MA.

25. Ding, Cherng G. and Timmy H. Tseng (2015), "On the Relationships Among Brand Experience, Hedonic Emotions, and Brand Equity," European Journal of Marketing, 49 (7/8), 994-1015.

26. Dube, Apramey and Anu Helkkula (2015), "Service Experiences Beyond the Direct Use: Indirect Customer Use Experiences of Smartphone Apps," Journal of Service Management, 26 (2), 224-48.

27. Dwivedi, Abhishek, Tahmid Nayeem, and Feisal Murshed (2018), "Brand Experience and Consumers' Willingness-to-Pay a Price Premium: Mediating Role of Brand Credibility and Perceived Uniqueness," Journal of Retailing and Consumer Services, 44, 100-107.

28. Ebrahim, Rehman, Ahmad Ghoneim, Zahir Irani, and Ying Fan (2016), "A Brand Preference and Repurchase Intention Model: The Role of Consumer Experience," Journal of Marketing Management, 32 (13/14), 1230-1259.

29. Edvardsson, Bo, Bo Enquist, and Robert Johnston (2005), "Cocreating Customer Value through Hyperreality in the Prepurchase Service Experience," Journal of Service Research, 8 (2), 149-61.

30. — - (2010), "Design Dimensions of Experience Rooms for Service Test Drives: Case studies in Several Service Contexts," Managing Service Quality, 20 (4), 312-27.

31. Ferguson, Ronald J., Michèle Paulin, and Jasmin Bergeron (2010), "Customer Sociability and the Total Service Experience: Antecedents of Positive Word-of-Mouth 
Intentions," Journal of Service Management, 21 (1), 25-44.

32. Fernandes, Teresa and Mariana Cruz (2016), "Dimensions and Outcomes of Experience Quality in Tourism: The Case of Port Wine Cellars," Journal of Retailing and Consumer Services, 31, 371-379.

33. Flacandji, Michaël and Nina Krey (2020), "Remembering Shopping Experiences: The Shopping Experience Memory Scale," Journal of Business Research, 107, 279-289.

34. Frow, Pennie and Adrian Payne (2007), "Towards the 'Perfect' Customer Experience," Brand Management, 15 (2), 89-101.

35. Gao, Lily Xuehui, Iguácel Melero-Polo, and F. Javier Sese (2020), “Customer Equity Drivers, Customer Experience Quality, and Customer Profitability in Banking Services: The Moderating Role of Social Influence," Journal of Service Research, forthcoming.

36. Gentile, Chiara, Nicola Spiller, and Giuliano Noci (2007), "How to Sustain the Customer Experience: An Overview of Experience Components that Co-create Value With the Customer," European Management Journal, 25 (5), 395-410.

37. Grewal, Dhruv, Michael Levy, and V. Kumar (2009), "Customer Experience Management in Retailing: An Organizing Framework," Journal of Retailing, 85 (1), 1 14.

38. Grove, Stephen J. and Raymond P. Fisk (1997), "The Impact of Other Customers on Service Experiences: A Critical Incident Examination of 'Getting Along, "Journal of Retailing, 73 (1), 63-85.

39. Gupta, Sudheer and Mirjana Vajic (2000), "The Contextual and Dialectical Nature of Experiences," in New Service Development: Creating Memorable Experience, J. A. Fitzsimmons and M. J. Fitzsimmons, eds., Thousand Oaks, CA: SAGE Publications, Inc., 33-51.

40. Helkkula, Anu (2011), "Characterising the Concept of Service Experience," Journal of Service Management, 22 (3), 367-89.

41. _ Carol Kelleher, and Minna Pihlstrom (2012a), "Practices and Experiences: Challenges and Opportunities for Value Research," Journal of Service Management, 23 (4), 554-70.

42. — - $\longrightarrow$, and (2012b), "Characterizing Value as an Experience: Implications for Service Researchers and Managers," Journal of Service Research, 15 (1), 59-75.

43. Hellén, Katarina and Johanna Gummerus (2013), "Re-investigating the Nature of Tangibility/Intangibility and its Influence on Consumer Experiences," Journal of Service Management, 24 (2), 130-50.

44. Hirschman, Elizabeth C. and Morris B. Holbrook (1982), "Hedonic Consumption Emerging Concepts, Methods and Propositions," Journal of Marketing, 46 (3), 92-101.

45. Hoffman, Donna L. and Thomas P. Novak (2018), "Consumer and Object Experience in the Internet of Things: An Assemblage Theory Approach," Journal of Consumer Research, 44 (6), 1178-1204.

46. Holbrook, Morris B. and Elizabeth C. Hirschman (1982), "The Experiential Aspects of Consumption - Consumer Fantasies, Feelings, and Fun," Journal of Consumer Research, 9 (2), 132-40.

47. Homburg, Cristian, Danijel Jozíc, and Christina Kuehnl (2017), "Customer Experience 
Management: Toward Implementing An Evolving Marketing Concept," Journal of the Academy of Marketing Science, 45 (3), 377-401.

48. Hui, Michael K. and John E. G. Bateson (1991), "Perceived Control and the Effects of Crowding and Consumer Choice on the Service Experience Stable," Journal of Consumer Research, 18 (2), 174-84.

49. Iglesias, Oriol, Jatinder J. Singh, and Joan M. Batista-Foguet (2011), "The Role of Brand Experience and Affective Commitment in Determining Brand Loyalty," Brand Management, 18 (8), 570-582.

50. Jaakkola, Elena, Anu Helkkula, and Leena Aarikka-Stenroos (2015), "Service Experience Co-Creation: Conceptualization, Implications, and Future Research Directions," Journal of Service Management, 26 (2), 182-205.

51. Jain, Rajnish, Jayesh Aagja, and Shilpa Bagdare (2017), "Customer Experience - A Review and Research Agenda," Journal of Service Theory and Practice, 27 (3), 642 662.

52. Jaziri, Dhouha (2019), "The Advent of Customer Experiential Knowledge Management Approach (CEKM ): The integration of offline \& online experiential knowledge," Journal of Business Research, 94, 241-56.

53. Johnston, Robert and Xiangyu Y. Kong (2011), “The Customer Experience: A RoadMap for Improvement," Managing Service Quality, 21 (1), 5-24.

54. Jüttner, Uta, Dorothea Schaffner, Katharina Windler, and Stan Maklan (2013), "Customer Service Experiences: Developing and Applying a Sequential Incident Laddering Technique," European Journal of Marketing, 47 (5/6), 738-768.

55. Kabadayi, Sertan, Faizan Ali, Hyeyoon Choi, Herm Joosten, and Can Lu (2019), "Smart Service Experience in Hospitality and Tourism Services: A Conceptualization and Future Research Agenda," Journal of Service Management, 30 (3), 326-348.

56. Keinan, Anat and Ran Kivetz (2011), "Productivity Orientation and the Consumption of Collectable Experiences," Journal of Consumer Research, 37 (6), 935-50.

57. Keiningham, Timothy L., Lerzan Aksoy, Helen L. Bruce, Fabienne Cadet, Natasha Clennell, Ian R Hodgkinson, and Treasa Kearney (2020), "Customer Experience Driven Business Model Innovation," Journal of Business Research, forthcoming.

58. Keiningham, Timothy L., Joan Ball, Sabine Benoit, Helen L. Bruce, Alexander Buoye, Julija Dzenkovska, Linda Nasr, Yi-Chun Ou, and Mohamed Zaki (2017), "Conceptualizing Customer Experience through the Lens of Customer Commitment," Journal of Services Marketing, 31 (2), 148-60.

59. Khan, Imran and Zillur Rahman (2016), "E-Tail Brand Experience's Influence on EBrand Trust and E-Brand Loyalty: The Moderating Role of Gender," International Journal of Retail \& Distribution Management, 44 (6), 588-606.

60. Kim, SeungHyun, JaeMin Cha, Bonnie J. Knutson, and Jeffrey A. Bock (2011), "Development and Testing of the Consumer Experience Index (CEI)," Managing Service Quality, 21 (2), 112-132.

61. Klaus, Philipp (2013), "The Case of Amazon.com: Towards a Conceptual Framework of Online Customer Service Experience (OCSE) Using the Emerging Consensus Technique (ECT)," Journal of Services Marketing, 27 (6), 443-57.

62. Klaus, Philipp and Stan Maklan (2012), "EXQ: A Multiple-Item Scale for Assessing 
Service Experience," Journal of Service Management, 23 (1), 5-33.

63. Knutson, Bonnie J. and Jeffrey A. Beck (2004), "Identifying the Dimensions of the Experience Construct," Journal of Quality Assurance in Hospitality \& Tourism, 4 (3-4), 23-35.

64. ——, Seung Hyun Kim, and Jaemin Cha (2007), "Identifying the Dimensions of the Experience Construct," Journal of Hospitality \& Leisure Marketing, 15 (3), 31-47.

65. Komulainen, Hanna and Saila Saraniemi (2019), "Customer Centricity in Mobile Banking: A Customer Experience Perspective," International Journal of Bank Marketing, 37 (5), 1082-1102.

66. Kranzbühler, Anne-Madeleine, Mirella H. P. Kleijnen, Robert E. Morgan, and Marije Teerling (2018), "The Multilevel Nature of Customer Experience Research : An Integrative Review and Research Agenda," International Journal of Management Reviews, 20 (2), 433-56.

67. — - and Peeter W. J. Verlegh (2019), "Outsourcing the Pain, Keeping the Pleasure: Effects of Outsourced Touchpoints in the Customer Journey," Journal of the Academy of Marketing Science, 47 (2), 308-27.

68. Kumar, Ravi Shekhar, Satyabhusan Dash, and Naresh K. Malhotra (2018), "The Impact of Marketing Activities on Service Brand Equity: The Mediating Role of Evoked Experience," European Journal of Marketing, 52 (3/4), 596-618.

69. Kumar, V., Bharath Rajan, Shaphali Gupta, and Ilaria Dalla Pozza (2019), "Customer Engagement in Service," Journal of the Academy of Marketing Science, 47 (1), 138-60.

70. - Nita Umashankar, Kihyun H. Kim, and Yashoda Bhagwat (2014), “Assessing the Influence of Economic and Customer Experience Factors on Service Purchase Behaviors," Marketing Science, 33 (5), 673-92.

71. Kuehnl, Christina, Jozic, Danijel, and Christian Homburg (2019), "Effective Customer Journey Design: Consumers' Conception, Measurement, and Consequences," Journal of the Academy of Marketing Science, 47 (3), 551-568.

72. Kuuru, Tiina-Kaisa and Elina Närvänen (2019), "Embodied Interaction in Customer Experience: A Phenomenological Study of Group Fitness," Journal of Marketing Management, 35 (13/14), 1241-1266.

73. Lanier, Clinton D. and C. Scott Rader (2015), "Consumption Experience: An Expanded View," Marketing Theory, 1-22.

74. Lemke, Fred, Moira Clark, and Hugh Wilson (2011), "Customer Experience Quality: An Exploration in Business and Consumer Contexts using Repertory Grid Technique," Journal of the Academy of Marketing Science, 39 (6), 846-69.

75. Lemon, Katherine N. and Peter C. Verhoef (2016), "Understanding Customer Experience and the Customer Journey," Journal of Marketing, 80 (November), 69-96.

76. Lipkin, Michaela (2016), “Customer Experience Formation in Today's Service Landscape," Journal of Service Management, 27 (5), 678-703.

77. Mahr, Dominik, Susan Stead, and Gaby Odekerken-schröder (2019), "Making Sense of Customer Service Experiences : A Text Mining Review," Journal of Services Marketing, 33 (1), 88-103.

78. Manthiou, Aikaterini, Seonjeong A. Lee, Liang R. Tang, and Lanlung Chiang (2014), 
"The Experience Economy Approach to Festival Marketing: Vivid Memory and Attendee Loyalty," Journal of Services Marketing, 28 (1), 22-35.

79. Martin, Jillian, Gary Mortimer, and Lynda Andrews (2015), "Re-Examining Online Customer Experience to Include Purchase Frequency and Perceived Risk," Journal of Retailing and Consumer Services, 25, 81-95.

80. McColl-Kennedy, Janet R., Anders Gustafsson, Elina Jaakkola, Philipp Klaus, Zoe Radnor, Helen Perks, and Margareta Friman (2015), "Fresh Perspectives on Customer Experience," Journal of Services Marketing, 29 (6/7), 430-35.

81. Mohamed Zaki, Katherine N. Lemon, Florian Urmetzer, and Andy Neely (2019), “Gaining Customer Experience Insights That Matter,” Journal of Service Research, 22 (1), 8-26.

82. Mclean, Graeme, Khalid Al-Nabhani, and Alan Wilson (2018), "Developing a Mobile Applications Customer Experience Model ( MACE ) - Implications for Retailers," Journal of Business Research, 85, 325-36.

83. Meyer, Christopher and Andre Schwager (2007), "Understanding Customer Experience," Harvard Business Review, 85 (2), 117-26.

84. Mohd-Ramly, Suhaily and Nor Asiah Omar (2017), "Exploring the Influence of Store Attributes on Customer Experience and Customer Engagement," International Journal of Retail \& Distribution Management, 45 (11), 1138-1158.

85. Morgan-Thomas, Anna and Cleopatra Veloutsou (2013), "Beyond Technology Acceptance: Brand Relationships and Online Brand Experience," Journal of Business Research, 66, 21-27.

86. Nambisan, Priya and James H. Watt (2011), "Managing Customer Experiences in Online Product Communities," Journal of Business Research, 64 (8), 889-95.

87. Nysveen, Herbjørn, Per E. Pedersen, Siv Skard (2013), "Brand Experiences in Service Organizations: Exploring the Individual Effects of Brand Experience Dimensions," Journal of Brand Management, 20 (5), 404-423.

88. Oh, Haemoon, Ann Marie Fiore, and Miyoung Jeoung (2007), "Measuring Experience Economy Concepts: Tourism Applications," Journal of Travel Research, 46, 119-132.

89. Otnes, Cele C., Behice E. Ilhan, and Atul Kukarni (2012), "The Language of Marketplace Rituals: Implications for Customer Experience Management," Journal of Retailing, 88 (3), 367-83.

90. Palmer, Adrian (2010), “Customer Experience Management: A Critical Review of An Emerging Idea,” Journal of Services Marketing, 24 (3), 196-208.

91. Patricio, Lia, Raymond P. Fisk, and João Falcão e Cunha Cunha (2008), "Designing Multi-Interface Service Experiences - The Service Experience Blueprint," Journal of Service Research, 10 (4), 318-34.

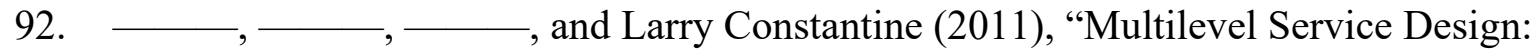
From Customer Value Constellation to Service Experience Blueprinting," Journal of Service Research, 14 (2), 180-200.

93. Payne, Adrian F., Kaj Storbacka, and Pennie Frow (2008), "Managing the Co-cCeation of Value," Journal of the Academy of Marketing Science, 36 (1), 83-96.

94. ——, — — , and Simon Knox (2009), “Co-Creating Brands: Diagnosing and Designing the Relationship Experience," Journal of Business Research, 62 (3), 
379-89.

95. Pine, B. Joseph and James H. Gilmore (1998), "Welcome to the Experience Economy," Harvard Business Review, 76 (4), 97-105.

96. Ponsignon, Frederic, Francois Durrieu, and Tatiana Bouzdine-Chameeva (2017), "Customer Experience Design: A Case Study in the Cultural Sector," Journal of Service Management, 28 (4), 763-87.

97. —— Philipp Klaus, and Roger S. Maull (2015), "Experience Co-Creation in Financial Services: An Empirical Exploration," Journal of Service Management, 26 (2), 295-320.

98. Prahalad, C. K. and Venkatram Ramaswamy (2003), "The New Frontier of Experience Innovation," MIT Sloan Management Review, 44 (4), 12-8.

99. _ - (2004), "Co-Creation Experiences: The Next Practice In Value Creation," Journal of Interactive Marketing, 18 (3), 5-14.

100. Puccinelli, Nancy M., Ronald C. Goodstein, Dhruv Grewal, Robert Price, Priya Raghubir, and David Stewart (2009), "Customer Experience Management in Retailing: Understanding the Buying Process," Journal of Retailing, 85 (1), 15-30.

101. Pullman, Madeleine E. and Michael A. Gross (2004), "Ability of Experience Design Elements to Elicit Emotions and Loyalty Behaviors," Decision Sciences, 35 (3), 55178.

102. Rawson, Alex, Ewan Duncan, and Conor Jones (2013), “Touchpoints Matter, But It's the Full Journey That Really Counts," Harvard Business Review, 91 (9), 90-98.

103. Rinallo, Diego, Stefania Borghini, and Franscesca Golfetto (2010), "Exploring Visitor Experiences at Trade Shows," Journal of Business \& Industrial Marketing, 25 (4), 249258.

104. Rose, Susan, Moira Clark, Phillip Samouel, and Neil Hair (2012), "Online Customer Experience in e-Retailing: An Empirical Model of Antecedents and Outcomes," Journal of Retailing, 88 (2), 308-22.

105. _ _ Neil Hair, and Moira Clark (2011), "Online Customer Experience: A Review of the Business-to-Consumer Online Purchase Context," International Journal of Management Reviews, 13 (1), 24-39.'

106. Roy, Sanjit K., Gaganpreet Singh, Megan Hope, Bang Nguyen, and Paul Harrigan (2019), "The Rise of Smart Consumers: Role of Smart Servicescape and Smart Consumer Experience Co-Creation," Journal of Marketing Management, 35 (15/16), 1480-1513.

107. Roy, Subhadip (2018), "Effects of customer experience across service types, customer types and time," Journal of Services Marketing, 32 (4), 400-413.

108. _ S. Sreejesh, and Sandhya Bhatia (2019), "Service Quality Versus Service Experience: An Empirical Examination of the Consequential Effects in B2B Services," Industrial Marketing Management, 82, 52-69.

109. Sändstrom, Sara, Bo Edvardsson, Per Kristensson, and Peter Magnusson (2008), "Value in Use Through Service Experience," Managing Service Quality, 18 (2), 112-26.

110. Schallehn, Holger, Stefan Seuring, Jochen Strähle, and Matthias Freise (2019), "Defining the Antecedents of Experience Co-Creation as Applied to Alternative Consumption Models," Journal of Service Management, 30 (2), 209-51. 
111. Schembri, Sharon (2006), "Rationalizing Service Logic, or Understanding Services as Experience?," Marketing Theory, 6 (3), 381-92.

112. Schmitt, Bernd H. (1999), Experiential Marketing, New York, NY: Free Press.

113. (2010), "Experience Marketing: Concepts, Frameworks and Consumer Insights," Foundations and Trends in Marketing, 5 (2), 55-112.

114. _ J. Jôsko Brakus, and Lio Zarantonello (2015), "From Experiential Psychology to Consumer Experience," Journal of Consumer Psychology, 25 (1), 166-71.

115. Schouten, John W., James H. McAlexander, and Harold F. Koenig (2007), "Transcendent Customer Experience and Brand Community," Journal of the Academy of Marketing Science, 35 (3), 357-68.

116. Scott, Rebecca, Julien Cayla, and Bernard Cova (2017), "Selling Pain to the Saturated Self," Journal of Consumer Research, 44 (1), 22-43.

117. Skandalis, Alexandros, John Byrom, and Emma Banister (2019), "Experiential Marketing and the Changing Nature of Extraodinary Experiences in Post-Modern Consumer Culture," Journal of Business Research, 97, 43-50.

118. Srivastava, Mala and Dimple Kaul (2016), "Exploring the Link Between Customer Experience-Loyalty-Consumer Spend," Journal of Retailing and Consumer Services, 31, 277-286.

119. Stein, Alisha and B. Ramaseshan (2016), "Towards the Identification of Customer Experience Touch Point Elements," Journal of Retailing and Consumer Services, 30, 819.

120. Still, Johanna, Hanna Komulainen, and Satu Nätti (2018), "Contextual Layers of Service Experience in Professional Business Services," Journal of Business \& Industrial Marketing, 33 (8), 1114-1124.

121. Stuart, Ian F. and Stephen S. Tax (2004), "Toward An Integrative Approach to Designing Service Experiences - Lessons Learned from the Theatre," Journal of Operations Management, 22, 609-27.

122. Sultan, Abdullah J. (2018), "Orchestrating Service Brand Touchpoints and the Effects on Relational Outcomes," Journal of Services Marketing, 32 (6), 777-88.

123. Tafesse, Wondwesen (2016), "An Experiential Model of Consumer Engagement in Social Media,” Journal of Product \& Brand Management, 25 (5), 424-434.

124. Tax, Stephen S., David McCutcheon, and Ian F. Wilkinson (2013), "The Service Delivery Network (SDN): A Customer-Centric Perspective of the Customer Journey," Journal of Service Research, 16 (4), 454-70.

125. Teixeira, Jorge, Lia Patricio, Nuno J. Nunes, Leonel Nobrega, Raymond P. Fisk, and Larry Constantine (2012), "Customer Experience Modeling: From Customer Experience to Service Design," Journal of Service Management, 23 (3), 362-76.

126. Thompson, Craig J., William B. Locander, and Howard R. Pollio (1989), "Putting Consumer Experience Back into Consumer Research - the Philosophy and Method of Existential Phenomenology," Journal of Consumer Research, 16 (2), 133-46.

127. Trischler, Jakob, Anita Zehrer, and Jessica Westman (2018), "A Designerly Way of Analyzing the Customer Experience," Journal of Service Management, 32 (7), 805-19.

128. Trudeau, Sabrina H. and Saeed Shobeiri (2016), "Does Social Currency Matter in Creation of Enhanced Brand Experience," Journal of Product \& Brand Management, 
$25(1), 98-114$.

129. Tumbat, Gülnur (2011), "Co-Constructing the Service Experience: Exploring the Role of Customer Emotion Management," Marketing Theory, 11 (2), 187-206.

130. and Russell W. Belk (2011), "Marketplace Tensions in Extraordinary Experiences," Journal of Consumer Research, 38 (1), 42-61.

131. Tynan, Caroline and Sally McKechnie (2009), "Experience Marketing: A Review and Reassessment," Journal of Marketing Management, 25 (5-6), 501-17.

132. Verhoef, Peter C., Katherine N. Lemon, A. Parasuraman, Anne Roggeveen, Michael Tsiros, and Leonard A. Schlesinger (2009), "Customer Experience Creation:

Determinants, Dynamics and Management Strategies," Journal of Retailing, 85 (1), 3141.

133. Verleye, Katrien (2015), "The Co-Creation Experience From The Customer Perspective: Its Measurement and Determinants," Journal of Service Management, 26 (2), 321-42.

134. Voorhees, Clay M., Paul W. Fombelle, Yany Gregoire, Sterling Bone, Anders Gustafsson, Rui Sousa, and Travis Walkowiak (2017), "Service Encounters, Experiences and the Customer Journey : Defining the Field and a Call to Expand our Lens," Journal of Business Research, 79 (November 2016), 269-80.

135. Voss, Chriss, Aleda V. Roth, and Richard B. Chase (2008), "Experience, Service Operations Strategy, and Services as Destinations: Foundations and Exploratory Investigation," Production and Operations Management, 17 (3), 247-66.

136. Walter, Ute, Bo Edvardsson, and Åsa Öström (2010), "Drivers of Customers' Service Experiences: A Study in the Restaurant Industry," Managing Service Quality, 20 (3), 236-258.

137. Wiedmann, Klaus-Peter, Franziska Labenz, Janina Haase, and Nadine Hennings (2018), "The Power of Experiential Marketing: Exploring the Causal Relationships Among Multisensory Marketing, Brand Experience, Customer Perceived Value and Brand Strength," Journal of Brand Management, 25, 101-118.

138. Winsted, Kathryn Frazer (1997), "The Service Experience In Two Cultures: A Behavioral Perspective," Journal of Retailing, 73 (3), 337-60.

139. Woermann, Niklas and Joonas Rokka (2015), "Timeflow: How Consumption Practices Shape Consumers' Temporal Experiences,” Journal of Consumer Research, 41 (6), 1486-1508.

140. Yakhlef, Ali (2015), "Customer Experience within Retail Environments: An Embodied, Spatial approach," Marketing Theory, 15 (4), 545-64.

141. Zehrer, Anita (2009), "Service Experience and Service Design: Concepts and Application in Tourism SMEs," Managing Service Quality, 19 (3), 332-349.

142. Zolkiewski, Judy, Victoria Story, Jamie Burton, Paul Chan, Andre Gomes, Philippa Hunter-jones, Lisa O Malley, Linda D. Peters, Chris Raddats, and William Robinson (2017), "Strategic B2B Customer Experience Management: The Importance of Outcomes-Based Measures," Journal of Services Marketing, 31 (2), 172-84.

143. Zomerdijk, Leonieke G. and Christopher A. Voss (2010), "Service Design for Experience-Centric Services,” Journal of Service Research, 13 (1), 67-82. 


\section{Web Appendix B. Coding Tree CX(M) Literature}

\begin{tabular}{|c|c|c|c|}
\hline $\begin{array}{l}\text { Third-order } \\
\text { categories }\end{array}$ & $\begin{array}{l}\text { Second-order } \\
\text { codes }\end{array}$ & First-order codes & Illustrative evidence \\
\hline \multirow[t]{3}{*}{ Touchpoint } & Nature & $\begin{array}{l}\text { - physical } \\
\text { - tangible } \\
\text { - human } \\
\text { - face-to-face } \\
\text { - digital } \\
\text { - electronic } \\
\text { - ... }\end{array}$ & $\begin{array}{l}\text { "tangible and intangible aspects of a retail store design" } \\
\text { (Puccinelli et al. 2009) "through face-to-face, electronic and other } \\
\text { channels" (Bolton et al. 2014) } \\
\text { "myriad touch points in multiple channels and media" (Lemon and } \\
\text { Verhoef 2016) }\end{array}$ \\
\hline & Control & $\begin{array}{l}\text { - direct } \\
\text { - planned } \\
\text { - firm-controlled } \\
\text { - indirect } \\
\text { - non-firm- } \\
\text { controlled } \\
\text { - ... }\end{array}$ & $\begin{array}{l}\text { "a consumption experience is not an experience planned by } \\
\text { particular market players" (Caru and Cova 2003) } \\
\text { "all direct and indirect encounters with the firm relating to their } \\
\text { purchasing behavior" (Klaus and Maklan 2013) } \\
\text { "involves multiple touchpoints, only some of which are under the } \\
\text { firm's control" (Trischler et al. 2018) }\end{array}$ \\
\hline & Stage & $\begin{array}{l}\text { - pre-purchase } \\
\text { - during purchase } \\
\text { - pre-consumption } \\
\text { - post-consumption } \\
\text { - after purchase } \\
\text { - ... }\end{array}$ & $\begin{array}{l}\text { "at any time before, during and after a purchase" (Hellén and } \\
\text { Gummerus 2013) } \\
\text { "during the entire customer journey" (McColl-Kennedy et al. } \\
2015) \\
\text { "the organization's offerings over time, including pre- and post- } \\
\text { consumption" (Bolton et al. 2018) }\end{array}$ \\
\hline \multirow[t]{4}{*}{ Context } & Individual context & $\begin{array}{l}\text { - subjective } \\
\text { - personal } \\
\text { - internal } \\
\text { - psychological } \\
\text { - interpretive } \\
\text { - } \ldots\end{array}$ & $\begin{array}{l}\text { "consumers imbue a product with a subjective meaning that } \\
\text { supplements the concrete attributes it possesses" (Hirschman and } \\
\text { Holbrook 1982) } \\
\text { "a strictly personal reaction ... comes from the affirmation of the } \\
\text { system of values and the beliefs of the person often through the } \\
\text { adoption of a lifestyle and behaviors" (Gentile et al. 2007) } \\
\text { "an actor's subjective response to or interpretation of the elements } \\
\text { of the service" (Jaakkola et al. 2015) }\end{array}$ \\
\hline & Social context & $\begin{array}{l}\text { - collective } \\
\text { - shared } \\
\text { - communal } \\
\text { - relational } \\
\text { - sociocultural } \\
\text { - } \ldots\end{array}$ & $\begin{array}{l}\text { "collective service experiences" (Caru and Cova 2003) } \\
\text { "relational component: a component of the Customer Experience } \\
\text { that involves the person and, beyond, his/her social context, } \\
\text { his/her relationship with other people" (Gentile et al. 2007) } \\
\text { "customer experience ... depend on sociocultural contingencies" } \\
\text { (Becker and Jaakkola 2020) }\end{array}$ \\
\hline & Market context & $\begin{array}{l}\text { - competitors } \\
\text { - service system } \\
\text { - networks } \\
\text { - value } \\
\text { constellations } \\
\text { - ... }\end{array}$ & $\begin{array}{l}\text { "potential situational moderators ... include ... competitive } \\
\text { intensity" (Verhoef et al. 2009) } \\
\text { "value constellation experience is cocreated through the } \\
\text { interactions between the customer and all service organizations } \\
\text { that enable a given customer activity" (Patricio et al. 2011) } \\
\text { "customers continuously judge the value of future service } \\
\text { experiences, both with the firm and with the firm's competitors" } \\
\text { (Jaakkola et al. 2015) }\end{array}$ \\
\hline & $\begin{array}{l}\text { Environmental } \\
\text { context }\end{array}$ & $\begin{array}{l}\text { - economic } \\
\text { - public } \\
\text { - political } \\
\text { - . . }\end{array}$ & $\begin{array}{l}\text { "customer experience factors matter more when economic times } \\
\text { are better" (Kumar et al. 2014) } \\
\text { "at the environmental level, multiple factors such as weather, } \\
\text { temperature, time of day, and traffic conditions can enhance or } \\
\text { undermine CX" (De Keyser et al. 2015) } \\
\text { "for example, external environments can act as influential drivers } \\
\text { of the customer experience (e.g., poor weather diminishing the } \\
\text { value of an outdoor sport event; political event influencing the } \\
\text { value of purchase or consumption of a product or service" (Lemon } \\
\text { and Verhoef 2016) } \\
\text { "the macro-level comprises higher-level structures such as } \\
\text { national economies, law systems, and political unions, and acts as } \\
\text { a stabilizing layer above the other two ... the macro-structures } \\
\text { have a direct impact on the CX" (De Keyser et al. 2015) }\end{array}$ \\
\hline
\end{tabular}




\begin{tabular}{|c|c|c|c|}
\hline $\begin{array}{l}\text { Third-order } \\
\text { categories }\end{array}$ & $\begin{array}{l}\text { Second-order } \\
\text { codes }\end{array}$ & First-order codes & Illustrative evidence \\
\hline \multirow[t]{5}{*}{ Qualities } & Participation level & $\begin{array}{l}\text { - compelling } \\
\text { - immersion } \\
\text { - involvement } \\
\text { - engagement } \\
\text { - . . }\end{array}$ & $\begin{array}{l}\text { "the complete engagement with and immersion in an activity" } \\
\text { (Hoffman and Novak 2009) } \\
\text { "resulting from customer contact with the retailer and which may } \\
\text { involve different levels of customer involvement" (Rose et al. } \\
2012 \text { ) } \\
\text { "at one end of the spectrum lies passive participation... at the } \\
\text { other end of the spectrum lies active participation, in which } \\
\text { customers play key roles in creating the performance of an event } \\
\text { that yields the experience" (Pine and Gilmore 1998) }\end{array}$ \\
\hline & Dimensionality & $\begin{array}{l}\text { - emotional } \\
\text { - affective } \\
\text { - social } \\
\text { - sensorial } \\
\text { - cognitive } \\
\text { - mental } \\
\text { - behavioral } \\
\text { - ... }\end{array}$ & $\begin{array}{l}\text { "sometimes multifaceted (cognitive, affective, emotional, social, } \\
\text { and physical) - response" (Lemke et al. 2011) } \\
\text { "customer's cognitive, emotional and behavioral responses" } \\
\text { (Chandler and Lusch 2014) } \\
\text { "a gestalt of affective and cognitive elements" (Roy 2018) }\end{array}$ \\
\hline & Valence & $\begin{array}{l}\text { - favorable } \\
\text { - positive } \\
\text { - good } \\
\text { - unfavorable } \\
\text { - negative } \\
\text { - bad } \\
\text { - neutral } \\
\text { - indifferent } \\
\text { - ... }\end{array}$ & $\begin{array}{l}\text { "customers always have an experience - good, bad or indifferent" } \\
\text { (Edvardsson et al. 2010) } \\
\text { "brand experiences also vary in valence; that is, some are more } \\
\text { positive than others, and some experiences may even be negative" } \\
\text { (Brakus et al. 2009) } \\
\text { "both favorable and unfavorable" (Akesson et al. 2014) }\end{array}$ \\
\hline & Ordinariness & $\begin{array}{l}\text { - day-to-day } \\
\text { - normal } \\
\text { - ordinary } \\
\text { - common } \\
\text { - mundane } \\
\text { - excelling } \\
\text { - unusual } \\
\text { - memorable } \\
\text { - unforgettable } \\
\text { - extraordinary } \\
\text { - transformative } \\
\text { - uncommon } \\
\text { - ... }\end{array}$ & $\begin{array}{l}\text { "extraordinary experience is triggered by unusual events and is } \\
\text { characterized by high levels of emotional intensity and } \\
\text { experience" (Arnould and Price 1993) } \\
\text { "the unusualness of the experience" (Schmitt 2010) } \\
\text { "While much of the research on customer experience has focused } \\
\text { on hedonic consumption emphasizing the individuals' } \\
\text { "extraordinary", "critical" or "peak" experiences (...), customer } \\
\text { experience is increasingly recognized in more mundane situations" } \\
\text { (McColl-Kennedy et al. 2015) }\end{array}$ \\
\hline & Timeflow & $\begin{array}{l}\text { - in the moment } \\
\text { - short-lived } \\
\text { - enduring } \\
\text { - extended } \\
\text { - long-lasting } \\
\text { - duration } \\
\text { - ... }\end{array}$ & $\begin{array}{l}\text { "the duration of an experience" (Bitran et al. 2008) } \\
\text { "some brand experiences occur spontaneously without much } \\
\text { reflection and are short-lived; others occur more deliberately and } \\
\text { last longer" (Brakus et al. 2009) } \\
\text { "experiences may be momentary, but also might be extended" } \\
\text { (Archpru et al. 2015) }\end{array}$ \\
\hline
\end{tabular}

The intercoder reliability for classifying the first-order codes in the second-order codes was calculated - as suggested by the reviewers - and Krippendorff's alpha (see Hayes and Krippendorff 2007 for more information) provided evidence for a high level of agreement among the two coders $(>90 \%)$.

Reference: Hayes, Andrew F. and Klaus Krippendorff, (2007), "Answering the call for a standard reliability measure for coding data," Communication Methods and Measures, 1(1), 77-89. 
Web Appendix C. Touchpoints in the CX(M) literature.

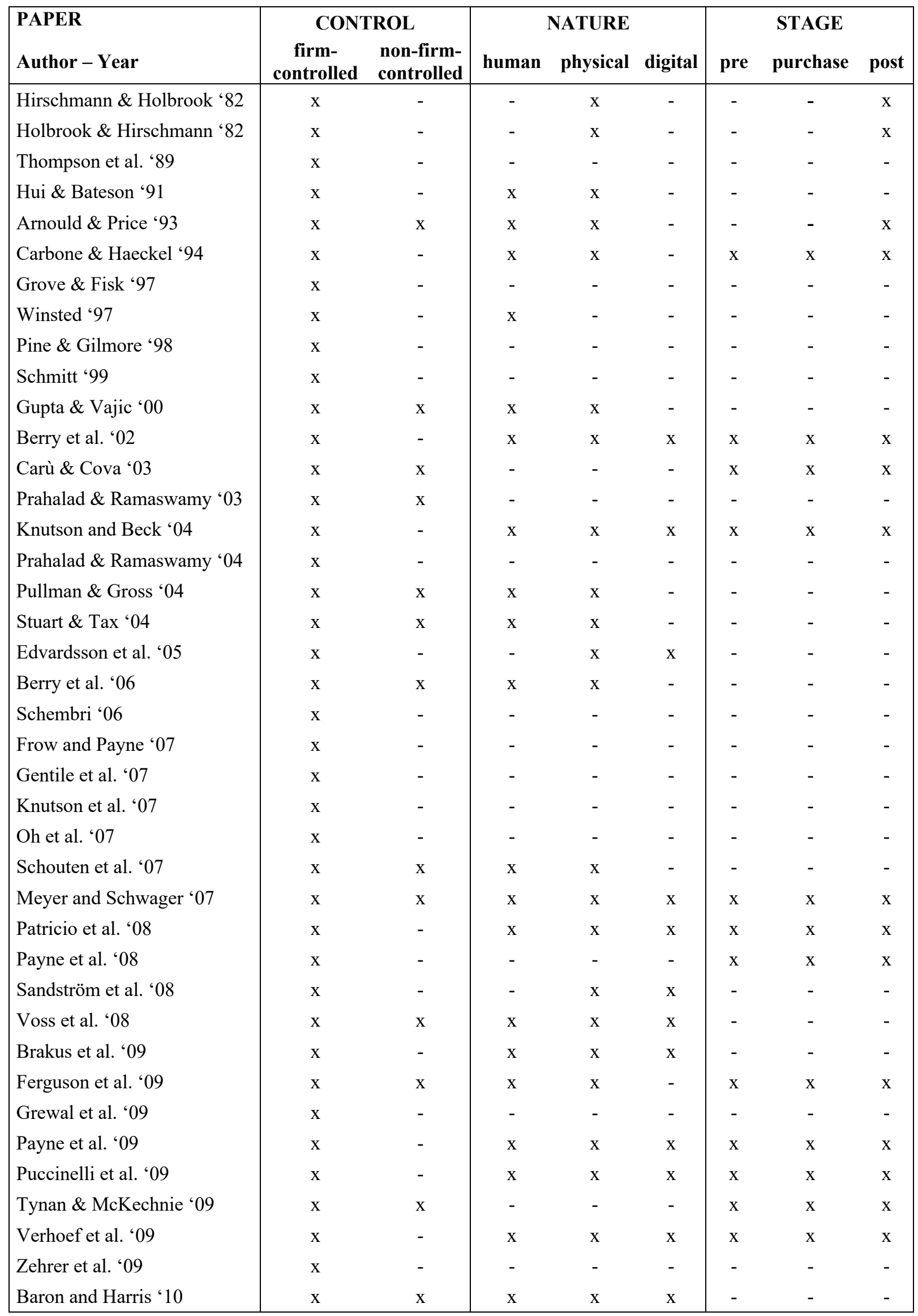




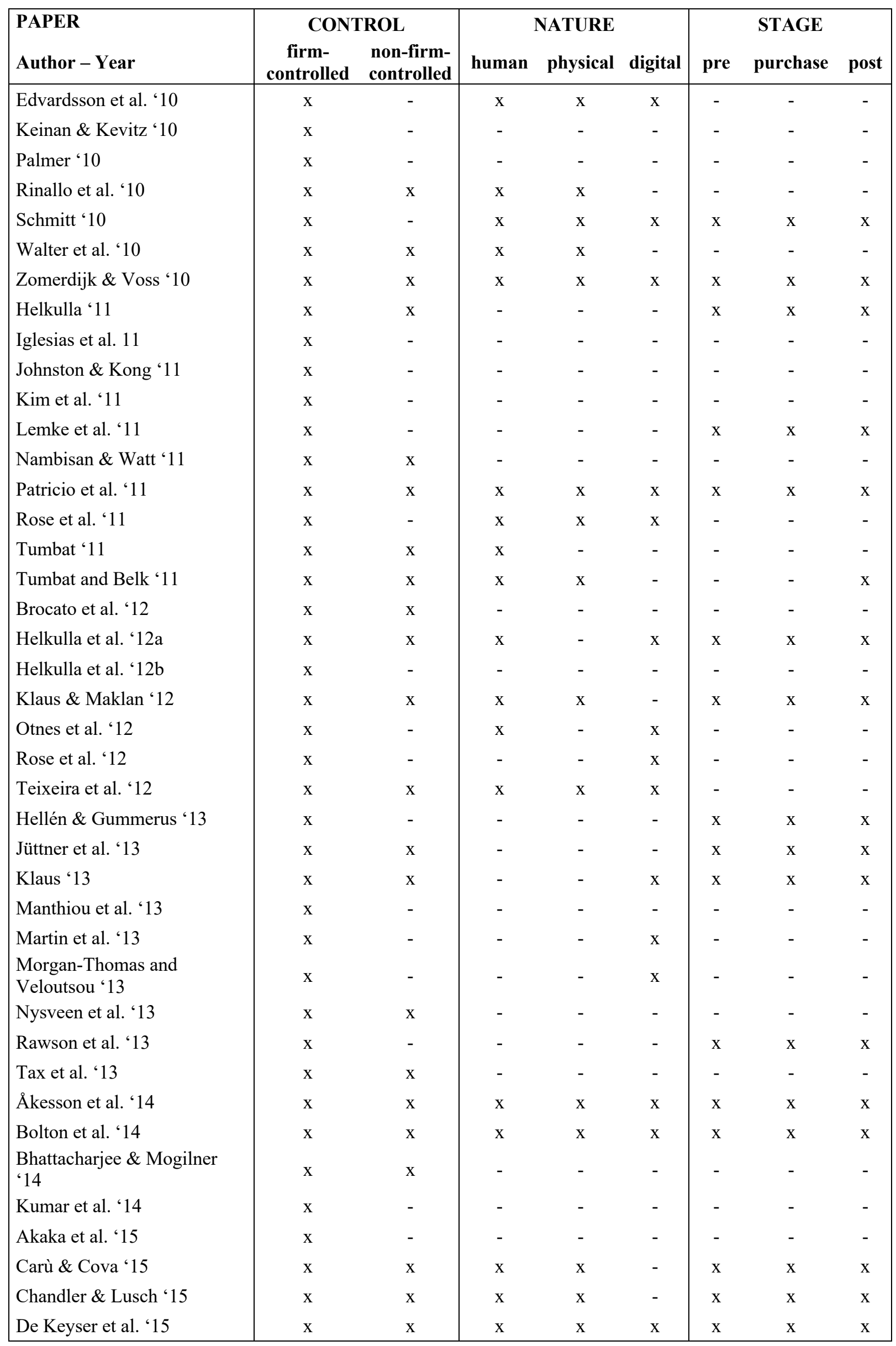




\begin{tabular}{|c|c|c|c|c|c|c|c|c|}
\hline \multirow{2}{*}{$\begin{array}{l}\text { PAPER } \\
\text { Author - Year } \\
\end{array}$} & \multicolumn{2}{|c|}{ CONTROL } & \multicolumn{3}{|c|}{ NATURE } & \multicolumn{3}{|c|}{ STAGE } \\
\hline & $\begin{array}{c}\text { firm- } \\
\text { controlled }\end{array}$ & $\begin{array}{l}\text { non-firm- } \\
\text { controlled }\end{array}$ & human & physical & digital & pre & purchase & post \\
\hline Ding and Tseng ' 15 & $\mathrm{x}$ & - & - & - & - & $\mathrm{x}$ & $\mathrm{x}$ & - \\
\hline Dube \& Helkkula ' 15 & $\mathrm{x}$ & $\mathrm{x}$ & $\mathrm{x}$ & $\mathrm{x}$ & $\mathrm{x}$ & - & - & - \\
\hline Jaakkola et al. 15 & $\mathrm{x}$ & $\mathrm{x}$ & - & - & - & $\mathrm{x}$ & $\mathrm{x}$ & $\mathrm{x}$ \\
\hline Lanier \& Rader ' 15 & $\mathrm{x}$ & - & - & - & - & - & - & - \\
\hline McColl-Kennedy et al. ' 15 & $\mathrm{x}$ & $\mathrm{x}$ & $\mathrm{x}$ & $\mathrm{x}$ & $\mathrm{x}$ & $\mathrm{x}$ & $\mathrm{x}$ & $\mathrm{x}$ \\
\hline Ponsignon et al. ' 15 & $\mathrm{x}$ & $\mathrm{x}$ & $\mathrm{x}$ & $\mathrm{x}$ & - & $\mathrm{x}$ & $\mathrm{x}$ & $\mathrm{x}$ \\
\hline Schmitt et al. ' 15 & $\mathrm{x}$ & - & $\mathrm{x}$ & $\mathrm{x}$ & - & - & - & $\mathrm{x}$ \\
\hline Verleye '15 & $\mathrm{x}$ & - & - & - & - & - & - & - \\
\hline Woermann \& Rokka '15 & $\mathrm{x}$ & $\mathrm{x}$ & - & $\mathrm{x}$ & - & - & - & - \\
\hline Yakhlef'15 & $\mathrm{x}$ & $\mathrm{x}$ & - & $\mathrm{x}$ & - & - & - & - \\
\hline Albrecht et al. ' 16 & $\mathrm{x}$ & - & $\mathrm{x}$ & - & - & - & - & - \\
\hline Anderson \& Smith '16 & $\mathrm{x}$ & - & - & - & - & - & - & - \\
\hline Beltagui et al. ' 16 & $\mathrm{x}$ & - & - & - & - & $\mathrm{x}$ & $\mathrm{x}$ & $\mathrm{x}$ \\
\hline Ebrahim et al. ' 16 & $\mathrm{x}$ & - & - & - & - & $\mathrm{x}$ & $\mathrm{x}$ & $\mathrm{x}$ \\
\hline Fernandes and Cruz '16 & $\mathrm{x}$ & - & - & - & - & - & - & - \\
\hline Khan and Rahman '16 & $\mathrm{x}$ & - & - & - & - & - & - & - \\
\hline Lemon \& Verhoef '16 & $\mathrm{x}$ & $\mathrm{x}$ & $\mathrm{x}$ & $\mathrm{x}$ & $\mathrm{x}$ & $\mathrm{x}$ & $\mathrm{x}$ & $\mathrm{x}$ \\
\hline Lipkin '16 & $\mathrm{x}$ & - & - & - & - & - & - & - \\
\hline Srivasrava and Kaul ‘'16 & $\mathrm{x}$ & - & - & - & - & - & - & - \\
\hline Stein and Ramaseshan '16 & $\mathrm{x}$ & $\mathrm{x}$ & $\mathrm{x}$ & $\mathrm{x}$ & $\mathrm{x}$ & $\mathrm{x}$ & $\mathrm{x}$ & $\mathrm{x}$ \\
\hline Tafesse ' 16 & $\mathrm{x}$ & - & - & $\mathrm{x}$ & $\mathrm{x}$ & - & - & - \\
\hline Trudeau and Shobeiri ' 16 & $\mathrm{x}$ & - & - & - & - & - & - & - \\
\hline Bustamante \& Rubio '17 & $\mathrm{x}$ & $\mathrm{x}$ & $\mathrm{x}$ & $\mathrm{x}$ & $\mathrm{x}$ & $\mathrm{x}$ & $\mathrm{x}$ & $\mathrm{x}$ \\
\hline Homburg et al. ' 17 & $\mathrm{x}$ & - & - & - & - & $\mathrm{x}$ & $\mathrm{x}$ & $\mathrm{x}$ \\
\hline Jain et al. '17 & $\mathrm{x}$ & $\mathrm{x}$ & $\mathrm{x}$ & $\mathrm{x}$ & $\mathrm{x}$ & $\mathrm{x}$ & $\mathrm{x}$ & $\mathrm{x}$ \\
\hline Keiningham et al. ' 17 & $\mathrm{x}$ & - & $\mathrm{x}$ & $\mathrm{x}$ & $\mathrm{x}$ & - & - & - \\
\hline Mohd-Ramly and Omar '17 & $\mathrm{x}$ & - & - & - & - & - & - & - \\
\hline Ponsignon et al. '17 & $\mathrm{x}$ & $\mathrm{x}$ & $\mathrm{x}$ & $\mathrm{x}$ & $\mathrm{x}$ & - & - & - \\
\hline Scott et al. ' 17 & $\mathrm{x}$ & $\mathrm{x}$ & $\mathrm{x}$ & $\mathrm{x}$ & - & - & $\mathrm{x}$ & $\mathrm{x}$ \\
\hline Voorhees et al. '17 & $\mathrm{x}$ & $\mathrm{x}$ & $\mathrm{x}$ & $\mathrm{x}$ & $\mathrm{x}$ & $\mathrm{x}$ & $\mathrm{x}$ & $\mathrm{x}$ \\
\hline Zolkiewski et al. ' 17 & $\mathrm{x}$ & $\mathrm{x}$ & $\mathrm{x}$ & - & - & - & - & - \\
\hline Bolton et al. ' 18 & $\mathrm{x}$ & $\mathrm{x}$ & $\mathrm{x}$ & $\mathrm{x}$ & $\mathrm{x}$ & $\mathrm{x}$ & $\mathrm{x}$ & $\mathrm{x}$ \\
\hline Collier et al. ' 18 & $\mathrm{x}$ & - & $\mathrm{x}$ & - & - & - & - & - \\
\hline Dwivedi et al. '18 & $\mathrm{x}$ & - & - & - & - & - & - & - \\
\hline Hoffman \& Novak '18 & $\mathrm{x}$ & $\mathrm{x}$ & - & - & $\mathrm{x}$ & - & - & - \\
\hline Kranzbühler et al. ' 18 & $\mathrm{x}$ & $\mathrm{x}$ & $\mathrm{x}$ & $\mathrm{x}$ & $\mathrm{x}$ & - & - & - \\
\hline Kumar et al. ' 18 & $\mathrm{x}$ & - & - & - & - & - & - & - \\
\hline McLean et al. ' 18 & $\mathrm{x}$ & - & - & - & $\mathrm{x}$ & - & - & - \\
\hline Roy '18 & $\mathrm{x}$ & - & - & - & - & - & - & - \\
\hline Roy et al. '18 & $\mathrm{x}$ & - & - & - & - & $\mathrm{x}$ & $\mathrm{x}$ & $\mathrm{x}$ \\
\hline Still et al. '18 & $\mathrm{x}$ & - & - & - & - & - & - & - \\
\hline Sultan '18 & $\mathrm{x}$ & - & - & - & - & $\mathrm{x}$ & $\mathrm{x}$ & $\mathrm{x}$ \\
\hline
\end{tabular}




\begin{tabular}{|c|c|c|c|c|c|c|c|c|}
\hline \multirow{2}{*}{$\begin{array}{l}\text { PAPER } \\
\text { Author - Year }\end{array}$} & \multicolumn{2}{|c|}{ CONTROL } & \multicolumn{3}{|c|}{ NATURE } & \multicolumn{3}{|c|}{ STAGE } \\
\hline & $\begin{array}{c}\text { firm- } \\
\text { controlled }\end{array}$ & $\begin{array}{l}\text { non-firm- } \\
\text { controlled } \\
\end{array}$ & human & physical & digital & pre & purchase & post \\
\hline Trischler et al. ' 18 & $\mathrm{x}$ & $\mathrm{x}$ & - & - & - & $\mathrm{x}$ & $\mathrm{x}$ & $\mathrm{x}$ \\
\hline Wiedmann et al. ' 18 & $\mathrm{x}$ & - & - & - & - & - & - & - \\
\hline Al-Wugayan ‘19 & $\mathrm{x}$ & - & - & - & - & - & - & - \\
\hline Bleier et al. '19 & $\mathrm{x}$ & $\mathrm{x}$ & - & - & $\mathrm{x}$ & $\mathrm{x}$ & $\mathrm{x}$ & - \\
\hline Jaziri '19 & $\mathrm{x}$ & $\mathrm{x}$ & - & - & - & - & - & - \\
\hline Kabadayi et al. '19 & $\mathrm{x}$ & - & - & - & $\mathrm{x}$ & - & - & - \\
\hline $\begin{array}{l}\text { Komulainen and Saraniemi } \\
\text { ' } 19\end{array}$ & $\mathrm{x}$ & $\mathrm{x}$ & - & - & - & $\mathrm{x}$ & $\mathrm{x}$ & $\mathrm{x}$ \\
\hline Kranzbühler et al. ‘19 & $\mathrm{x}$ & $\mathrm{x}$ & - & - & - & - & - & - \\
\hline Kuehnl et al. '19 & $\mathrm{x}$ & $\mathrm{x}$ & - & - & - & $\mathrm{x}$ & $\mathrm{x}$ & $\mathrm{x}$ \\
\hline Kumar et al. ' 19 & $\mathrm{x}$ & $\mathrm{x}$ & $\mathrm{x}$ & - & $\mathrm{x}$ & - & - & - \\
\hline Kuuru and Närvänen '19 & $\mathrm{x}$ & $\mathrm{x}$ & $\mathrm{x}$ & $\mathrm{x}$ & $\mathrm{x}$ & $\mathrm{x}$ & $\mathrm{x}$ & $\mathrm{x}$ \\
\hline Mahr et al. '19 & $\mathrm{x}$ & $\mathrm{x}$ & $\mathrm{x}$ & $\mathrm{x}$ & $\mathrm{x}$ & - & - & - \\
\hline McColl-Kennedy et al. '19 & $\mathrm{x}$ & - & - & - & - & - & - & $\mathrm{x}$ \\
\hline Roy et al. '19 & $\mathrm{x}$ & $\mathrm{x}$ & $\mathrm{x}$ & $\mathrm{x}$ & $\mathrm{x}$ & - & - & - \\
\hline Schallehn et al. ' 19 & $\mathrm{x}$ & $\mathrm{x}$ & - & - & - & $\mathrm{x}$ & $\mathrm{x}$ & $\mathrm{x}$ \\
\hline Skandalis et al. ' 19 & $\mathrm{x}$ & $\mathrm{x}$ & - & - & - & - & - & - \\
\hline Becker and Jaakkola '20 & $\mathrm{x}$ & $\mathrm{x}$ & $\mathrm{x}$ & $\mathrm{x}$ & $\mathrm{x}$ & $\mathrm{x}$ & $\mathrm{x}$ & $\mathrm{x}$ \\
\hline Flacandji \& Krey '20 & $\mathrm{x}$ & - & - & - & - & $\mathrm{x}$ & $\mathrm{x}$ & $\mathrm{x}$ \\
\hline Gao et al. '20 & $\mathrm{x}$ & $\mathrm{x}$ & - & - & - & - & - & - \\
\hline Keiningham et al. '20 & $\mathrm{x}$ & - & $\mathrm{x}$ & - & $\mathrm{x}$ & $\mathrm{x}$ & $\mathrm{x}$ & $\mathrm{x}$ \\
\hline
\end{tabular}


Web Appendix D. Context in the CX(M) literature.

\begin{tabular}{|c|c|c|c|c|c|}
\hline $\begin{array}{l}\text { PAPER } \\
\text { Author - Year }\end{array}$ & $\begin{array}{l}\text { context } \\
\text { matters }\end{array}$ & $\begin{array}{c}\text { individual } \\
\text { context }\end{array}$ & $\begin{array}{l}\text { social } \\
\text { context }\end{array}$ & $\begin{array}{l}\text { market } \\
\text { context }\end{array}$ & $\begin{array}{c}\text { environmental } \\
\text { context }\end{array}$ \\
\hline Hirschmann \& Holbrook '82 & $\mathrm{x}$ & $\mathrm{x}$ & - & - & - \\
\hline Holbrook \& Hirschmann '82 & $\mathrm{x}$ & $\mathrm{x}$ & - & - & - \\
\hline Thompson et al. '89 & $\mathrm{x}$ & $\mathrm{x}$ & - & - & - \\
\hline Hui \& Bateson ‘91 & $\mathrm{x}$ & $\mathrm{x}$ & $\mathrm{x}$ & - & - \\
\hline Arnould \& Price '93 & $\mathrm{x}$ & $\mathrm{x}$ & - & - & - \\
\hline Carbone \& Haeckel ‘94 & - & - & - & - & - \\
\hline Grove \& Fisk '97 & $\mathrm{x}$ & - & $\mathrm{x}$ & - & - \\
\hline Winsted '97 & $\mathrm{x}$ & $\mathrm{x}$ & - & - & - \\
\hline Pine \& Gilmore '98 & $\mathrm{x}$ & - & - & - & $\mathrm{x}$ \\
\hline Schmitt ‘99 & $\mathrm{x}$ & - & $\mathrm{x}$ & - & - \\
\hline Gupta \& Vajic '00 & $\mathrm{x}$ & $\mathrm{x}$ & $\mathrm{x}$ & - & - \\
\hline Berry et al. ' 02 & - & - & - & - & - \\
\hline Carù \& Cova '03 & $\mathrm{x}$ & - & - & - & - \\
\hline Prahalad \& Ramaswamy '03 & $\mathrm{x}$ & $\mathrm{x}$ & - & - & - \\
\hline Knutson and Beck '04 & $\mathrm{x}$ & $\mathrm{x}$ & - & - & - \\
\hline Prahalad \& Ramaswamy '04 & $\mathrm{x}$ & $\mathrm{x}$ & - & - & - \\
\hline Pullman \& Gross ‘04 & - & - & - & - & - \\
\hline Stuart \& Tax '04 & - & - & - & - & - \\
\hline Edvardsson et al. '05 & $\mathrm{x}$ & $\mathrm{x}$ & - & - & - \\
\hline Berry et al. '06 & - & - & - & - & - \\
\hline Schembri '06 & - & - & - & - & - \\
\hline Frow and Payne '07 & $\mathrm{x}$ & - & - & - & - \\
\hline Gentile et al. '07 & $\mathrm{x}$ & $\mathrm{x}$ & $\mathrm{x}$ & - & - \\
\hline Knutson et al. '07 & $\mathrm{x}$ & $\mathrm{x}$ & - & - & - \\
\hline Oh et al. '07 & $\mathrm{x}$ & - & - & - & - \\
\hline Schouten et al. '07 & - & - & - & - & - \\
\hline Meyer and Schwager '07 & $\mathrm{x}$ & $\mathrm{x}$ & - & - & - \\
\hline Patricio et al. '08 & $\mathrm{x}$ & $\mathrm{x}$ & - & - & - \\
\hline Payne et al. '08 & - & - & - & - & - \\
\hline Sandström et al. ' 08 & $\mathrm{x}$ & $\mathrm{x}$ & - & - & - \\
\hline Voss et al. '08 & $\mathrm{x}$ & - & - & - & - \\
\hline Brakus et al. '09 & $\mathrm{x}$ & - & - & - & - \\
\hline Ferguson et al. '09 & - & - & - & - & - \\
\hline Grewal et al. '09 & $\mathrm{x}$ & - & - & - & $\mathrm{x}$ \\
\hline Payne et al. '09 & - & - & - & - & - \\
\hline Puccinelli et al. '09 & $\mathrm{x}$ & $\mathrm{x}$ & - & - & - \\
\hline Tynan \& McKechnie '09 & - & - & - & - & - \\
\hline Verhoef et al. '09 & $\mathrm{x}$ & $\mathrm{x}$ & $\mathrm{x}$ & $\mathrm{x}$ & $\mathrm{x}$ \\
\hline Zehrer et al. '09 & - & - & - & - & - \\
\hline Baron and Harris ' 10 & $\mathrm{x}$ & $\mathrm{x}$ & $\mathrm{x}$ & $\mathrm{x}$ & - \\
\hline
\end{tabular}




\begin{tabular}{|c|c|c|c|c|c|}
\hline $\begin{array}{l}\text { PAPER } \\
\text { Author - Year }\end{array}$ & $\begin{array}{l}\text { context } \\
\text { matters }\end{array}$ & $\begin{array}{c}\text { individual } \\
\text { context }\end{array}$ & $\begin{array}{c}\text { social } \\
\text { context }\end{array}$ & $\begin{array}{l}\text { market } \\
\text { context }\end{array}$ & $\begin{array}{c}\text { environmental } \\
\text { context }\end{array}$ \\
\hline Edvardsson et al. '10 & $\mathrm{x}$ & $\mathrm{x}$ & $\mathrm{x}$ & - & - \\
\hline Keinan \& Kevitz '10 & $\mathrm{x}$ & $\mathrm{x}$ & - & - & - \\
\hline Palmer ' 10 & $\mathrm{x}$ & - & - & - & - \\
\hline Rinallo et al. ' 10 & - & - & - & - & - \\
\hline Schmitt ' 10 & $\mathrm{x}$ & - & - & - & - \\
\hline Walter et al. ' 10 & $\mathrm{x}$ & $\mathrm{x}$ & $\mathrm{x}$ & - & - \\
\hline Zomerdijk \& Voss ' 10 & - & - & - & - & - \\
\hline Helkulla '11 & $\mathrm{x}$ & $\mathrm{x}$ & - & - & - \\
\hline Iglesias et al. 11 & $\mathrm{x}$ & $\mathrm{x}$ & - & - & - \\
\hline Johnston \& Kong '11 & $\mathrm{x}$ & - & - & - & - \\
\hline Kim et al. '11 & $\mathrm{x}$ & $\mathrm{x}$ & - & - & - \\
\hline Lemke et al. '11 & $\mathrm{x}$ & - & - & - & - \\
\hline Nambisan \& Watt '11 & - & - & - & - & - \\
\hline Patricio et al. '11 & $\mathrm{x}$ & $\mathrm{x}$ & - & $\mathrm{x}$ & - \\
\hline Rose et al. ' 11 & $\mathrm{x}$ & $\mathrm{x}$ & - & - & - \\
\hline Tumbat '11 & $\mathrm{x}$ & $\mathrm{x}$ & - & - & - \\
\hline Tumbat and Belk '11 & $\mathrm{x}$ & $\mathrm{x}$ & - & - & - \\
\hline Brocato et al. '12 & - & - & - & - & - \\
\hline Helkulla et al. '12a & $\mathrm{x}$ & $\mathrm{x}$ & $\mathrm{x}$ & - & - \\
\hline Helkulla et al. ' $12 b$ & $\mathrm{x}$ & $\mathrm{x}$ & $\mathrm{x}$ & - & - \\
\hline Klaus \& Maklan '12 & $\mathrm{x}$ & $\mathrm{x}$ & - & - & - \\
\hline Otnes et al. ' 12 & $\mathrm{x}$ & $\mathrm{x}$ & - & - & - \\
\hline Rose et al. ' 12 & $\mathrm{x}$ & $\mathrm{x}$ & - & - & - \\
\hline Teixeira et al. '12 & $\mathrm{x}$ & $\mathrm{x}$ & $\mathrm{x}$ & $\mathrm{x}$ & - \\
\hline Hellén \& Gummerus '13 & - & - & - & - & - \\
\hline Jüttner et al. '13 & $\mathrm{x}$ & $\mathrm{x}$ & - & - & - \\
\hline Klaus ' 13 & $\mathrm{x}$ & - & - & - & - \\
\hline Manthiou et al. '13 & $\mathrm{x}$ & $\mathrm{x}$ & - & - & - \\
\hline Martin et al. ' 13 & $\mathrm{x}$ & $\mathrm{x}$ & - & - & - \\
\hline $\begin{array}{l}\text { Morgan-Thomas and Veloutsou } \\
\text { ' } 13\end{array}$ & $\mathrm{x}$ & $\mathrm{x}$ & - & - & - \\
\hline Nysveen et al. '13 & $\mathrm{x}$ & $\mathrm{x}$ & - & - & - \\
\hline Rawson et al. ' 13 & $\mathrm{x}$ & $\mathrm{x}$ & - & - & - \\
\hline Tax et al. ' 13 & $\mathrm{x}$ & - & - & $\mathrm{x}$ & - \\
\hline Åkesson et al. '14 & $\mathrm{x}$ & $\mathrm{x}$ & $\mathrm{x}$ & - & - \\
\hline Bolton et al. '14 & $\mathrm{x}$ & $\mathrm{x}$ & - & - & - \\
\hline Bhattacharjee \& Mogilner '14 & $\mathrm{x}$ & $\mathrm{x}$ & - & - & - \\
\hline Kumar et al. '14 & $\mathrm{x}$ & - & - & - & $\mathrm{x}$ \\
\hline Akaka et al. ' 15 & $\mathrm{x}$ & $\mathrm{x}$ & $\mathrm{x}$ & - & - \\
\hline Carù \& Cova '15 & $\mathrm{x}$ & $\mathrm{x}$ & - & - & - \\
\hline Chandler \& Lusch '15 & $\mathrm{x}$ & $\mathrm{x}$ & - & - & - \\
\hline De Keyser et al. ' 15 & $\mathrm{x}$ & $\mathrm{x}$ & $\mathrm{x}$ & $\mathrm{x}$ & $\mathrm{x}$ \\
\hline Ding and Tseng ' 15 & $\mathrm{x}$ & $\mathrm{x}$ & - & - & - \\
\hline
\end{tabular}




\begin{tabular}{|c|c|c|c|c|c|}
\hline $\begin{array}{l}\text { PAPER } \\
\text { Author - Year }\end{array}$ & $\begin{array}{l}\text { context } \\
\text { matters }\end{array}$ & $\begin{array}{c}\text { individual } \\
\text { context }\end{array}$ & $\begin{array}{c}\text { social } \\
\text { context }\end{array}$ & $\begin{array}{l}\text { market } \\
\text { context }\end{array}$ & $\begin{array}{c}\text { environmental } \\
\text { context }\end{array}$ \\
\hline Dube \& Helkkula '15 & $\mathrm{x}$ & $\mathrm{x}$ & - & - & - \\
\hline Jaakkola et al. 15 & $\mathrm{x}$ & $\mathrm{x}$ & $\mathrm{x}$ & $\mathrm{x}$ & - \\
\hline Lanier \& Rader '15 & - & - & - & - & - \\
\hline McColl-Kennedy et al. '15 & $\mathrm{x}$ & $\mathrm{x}$ & - & - & - \\
\hline Ponsignon et al. ' 15 & $\mathrm{x}$ & - & - & - & - \\
\hline Schmitt et al. ' 15 & $\mathrm{x}$ & - & $\mathrm{x}$ & - & - \\
\hline Verleye ' 15 & $\mathrm{x}$ & $\mathrm{x}$ & $\mathrm{x}$ & - & - \\
\hline Woermann \& Rokka '15 & $\mathrm{x}$ & $\mathrm{x}$ & $\mathrm{x}$ & - & - \\
\hline Yakhlef'15 & $\mathrm{x}$ & $\mathrm{x}$ & - & - & - \\
\hline Albrecht et al. ' 16 & - & - & - & - & - \\
\hline Anderson \& Smith '16 & $\mathrm{x}$ & - & - & - & - \\
\hline Beltagui et al. ' 16 & $\mathrm{x}$ & $\mathrm{x}$ & - & - & - \\
\hline Ebrahim et al. ' 16 & $\mathrm{x}$ & $\mathrm{x}$ & - & - & - \\
\hline Fernandes and Cruz ' 16 & $\mathrm{x}$ & $\mathrm{x}$ & - & - & - \\
\hline Khan and Rahman '16 & - & - & - & - & - \\
\hline Lemon \& Verhoef '16 & $\mathrm{x}$ & $\mathrm{x}$ & - & - & - \\
\hline Lipkin '16 & $\mathrm{x}$ & $\mathrm{x}$ & $\mathrm{x}$ & $\mathrm{x}$ & - \\
\hline Srivasrava and Kaul ' 16 & - & - & - & - & - \\
\hline Stein and Ramaseshan '16 & $\mathrm{x}$ & $\mathrm{x}$ & - & - & - \\
\hline Tafesse ' 16 & $\mathrm{x}$ & $\mathrm{x}$ & - & - & - \\
\hline Trudeau and Shobeiri ' 16 & - & - & - & - & - \\
\hline Bustamante \& Rubio '17 & $\mathrm{x}$ & $\mathrm{x}$ & - & - & - \\
\hline Homburg et al. ' 17 & $\mathrm{x}$ & - & - & - & - \\
\hline Jain et al. '17 & $\mathrm{x}$ & $\mathrm{x}$ & $\mathrm{x}$ & $\mathrm{x}$ & $\mathrm{x}$ \\
\hline Keiningham et al. ' 17 & $\mathrm{x}$ & $\mathrm{x}$ & $\mathrm{x}$ & - & - \\
\hline Mohd-Ramly and Omar '17 & - & - & - & - & - \\
\hline Ponsignon et al. '17 & $\mathrm{x}$ & $\mathrm{x}$ & - & - & - \\
\hline Scott et al. ' 17 & $\mathrm{x}$ & $\mathrm{x}$ & $\mathrm{x}$ & - & - \\
\hline Voorhees et al. '17 & - & - & - & - & - \\
\hline Zolkiewski et al. ' 17 & $\mathrm{x}$ & $\mathrm{x}$ & $\mathrm{x}$ & - & - \\
\hline Bolton et al. '18 & $\mathrm{x}$ & $\mathrm{x}$ & $\mathrm{x}$ & $\mathrm{x}$ & $\mathrm{x}$ \\
\hline Colliet et al. '18 & - & - & - & - & - \\
\hline Dwivedi et al. '18 & - & - & - & - & - \\
\hline Hoffman \& Novak '18 & $\mathrm{x}$ & $\mathrm{x}$ & - & $\mathrm{x}$ & - \\
\hline Kranzbühler et al. ' 18 & $\mathrm{x}$ & $\mathrm{x}$ & $\mathrm{x}$ & - & - \\
\hline Kumar et al. ' 18 & - & - & - & - & - \\
\hline McLean et al. ' 18 & - & - & - & - & - \\
\hline Roy ‘18 & $\mathrm{x}$ & $\mathrm{x}$ & - & - & - \\
\hline Roy et al. ' 18 & $\mathrm{x}$ & $\mathrm{x}$ & - & - & - \\
\hline Still et al. ' 18 & $\mathrm{x}$ & $\mathrm{x}$ & $\mathrm{x}$ & $\mathrm{x}$ & $\mathrm{x}$ \\
\hline Sultan '18 & - & - & - & - & - \\
\hline Trischler et al. ' 18 & $\mathrm{x}$ & $\mathrm{x}$ & $\mathrm{x}$ & $\mathrm{x}$ & - \\
\hline
\end{tabular}




\begin{tabular}{|l|c|cccc|}
\hline PAPER & $\begin{array}{c}\text { context } \\
\text { matters }\end{array}$ & $\begin{array}{c}\text { individual } \\
\text { context }\end{array}$ & $\begin{array}{c}\text { social } \\
\text { context }\end{array}$ & $\begin{array}{c}\text { market } \\
\text { context }\end{array}$ & $\begin{array}{c}\text { environmental } \\
\text { context }\end{array}$ \\
\hline Wiedmann et al. '18 & $\mathrm{x}$ & $\mathrm{x}$ & - & - & - \\
Al-Wugayan '19 & - & - & - & - & - \\
Bleier et al. '19 & $\mathrm{x}$ & $\mathrm{x}$ & - & - & - \\
Jaziri '19 & $\mathrm{x}$ & $\mathrm{x}$ & - & - & - \\
Kabadayi et al. '19 & $\mathrm{x}$ & $\mathrm{x}$ & - & - & - \\
Komulainen and Saraniemi '19 & $\mathrm{x}$ & $\mathrm{x}$ & $\mathrm{x}$ & - & - \\
Kranzbühler et al. '19 & - & - & - & - & - \\
Kuehnl et al. '19 & $\mathrm{x}$ & - & - & - & - \\
Kumar et al. '19 & $\mathrm{x}$ & $\mathrm{x}$ & $\mathrm{x}$ & $\mathrm{x}$ & $\mathrm{x}$ \\
Kuuru and Närvänen '19 & $\mathrm{x}$ & $\mathrm{x}$ & $\mathrm{x}$ & - & - \\
Mahr et al. '19 & $\mathrm{x}$ & - & - & - & - \\
McColl-Kennedy et al. '19 & $\mathrm{x}$ & $\mathrm{x}$ & - & $\mathrm{x}$ & - \\
Roy et al. '19 & $\mathrm{x}$ & $\mathrm{x}$ & - & - & - \\
Schallehn et al. '19 & $\mathrm{x}$ & $\mathrm{x}$ & $\mathrm{x}$ & - & - \\
Skandalis et al. '19 & $\mathrm{x}$ & $\mathrm{x}$ & $\mathrm{x}$ & - & $\mathrm{x}$ \\
Becker and Jaakkola '20 & $\mathrm{x}$ & $\mathrm{x}$ & $\mathrm{x}$ & $\mathrm{x}$ & - \\
Flacandji \& Krey '20 & $\mathrm{x}$ & $\mathrm{x}$ & - & - & - \\
Gao et al. '20 & $\mathrm{x}$ & $\mathrm{x}$ & - & - & - \\
Keiningham et al. '20 & $\mathrm{x}$ & $\mathrm{x}$ & $\mathrm{x}$ & $\mathrm{x}$ & - \\
\hline
\end{tabular}


Web Appendix E. Qualities in the CX(M) literature.

\begin{tabular}{|c|c|c|c|c|c|c|c|c|c|c|c|c|c|}
\hline \multirow{2}{*}{$\begin{array}{l}\text { PAPER } \\
\text { Author - Year }\end{array}$} & \multirow[b]{2}{*}{$\begin{array}{l}\text { PARTICIPATION } \\
\text { LEVEL }\end{array}$} & \multicolumn{5}{|c|}{ DIMENSIONALITY } & \multicolumn{2}{|c|}{ TEMPORALITY } & \multicolumn{3}{|c|}{ VALENCE } & \multicolumn{2}{|c|}{ ORDINARINESS } \\
\hline & & 氞 & 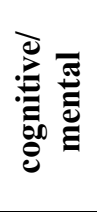 & 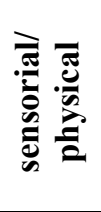 & 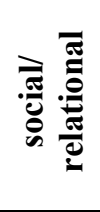 & 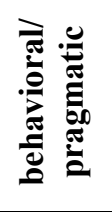 & 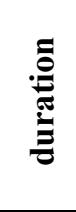 & 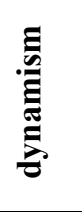 & $\stackrel{0}{:}$ & 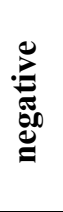 & : & : & 预 \\
\hline Hirschmann \& Holbrook '82 & - & $\mathrm{x}$ & $\mathrm{x}$ & $\mathrm{x}$ & - & - & - & $\mathrm{x}$ & - & - & - & - & - \\
\hline Holbrook \& Hirschmann ' 82 & $\mathrm{x}$ & $\mathrm{x}$ & $\mathrm{x}$ & $\mathrm{x}$ & - & - & - & - & - & - & - & - & - \\
\hline Thompson et al. ' 89 & - & $\mathrm{x}$ & $\mathrm{x}$ & - & - & - & - & $\mathrm{x}$ & - & - & - & - & - \\
\hline Hui \& Bateson '91 & - & $\mathrm{x}$ & - & - & - & - & - & - & - & - & - & - & - \\
\hline Arnould \& Price '93 & - & $\mathrm{x}$ & - & - & $\mathrm{x}$ & - & - & - & $\mathrm{x}$ & - & - & $\mathrm{x}$ & $\mathrm{x}$ \\
\hline Carbone \& Haeckel '94 & - & - & - & - & - & - & - & - & $\mathrm{x}$ & $\mathrm{x}$ & - & - & - \\
\hline Grove \& Fisk ‘97 & $\mathrm{x}$ & - & $\mathrm{x}$ & - & - & - & $\mathrm{x}$ & - & - & - & - & - & - \\
\hline Winsted '97 & - & - & $\mathrm{x}$ & - & - & - & - & - & - & - & - & - & - \\
\hline Pine \& Gilmore ‘98 & $\mathrm{x}$ & $\mathrm{x}$ & $\mathrm{x}$ & $\mathrm{x}$ & - & - & - & - & - & - & - & $\mathrm{x}$ & $\mathrm{x}$ \\
\hline Schmitt ‘99 & - & $\mathrm{x}$ & $\mathrm{x}$ & $\mathrm{x}$ & $\mathrm{x}$ & $\mathrm{x}$ & - & - & - & - & - & - & - \\
\hline Gupta \& Vajic '00 & $\mathrm{x}$ & - & $\mathrm{x}$ & - & - & - & - & - & - & - & - & - & $\mathrm{x}$ \\
\hline Berry et al. '02 & - & $\mathrm{x}$ & $\mathrm{x}$ & - & - & - & - & - & $\mathrm{x}$ & $\mathrm{x}$ & $\mathrm{x}$ & - & - \\
\hline Carù \& Cova '03 & - & $\mathrm{x}$ & $\mathrm{x}$ & - & - & $\mathrm{x}$ & - & - & $\mathrm{x}$ & - & - & $\mathrm{x}$ & $\mathrm{x}$ \\
\hline Prahalad \& Ramaswamy '03 & $\mathrm{x}$ & - & - & - & - & - & - & - & - & - & - & - & - \\
\hline Knutson and Beck '04 & $\mathrm{x}$ & - & - & - & - & - & - & - & - & - & - & - & - \\
\hline Prahalad \& Ramaswamy ‘04 & $\mathrm{x}$ & - & - & - & - & - & - & - & - & - & - & - & - \\
\hline Pullman and Gross '04 & $\mathrm{x}$ & $\mathrm{x}$ & - & - & - & - & - & - & - & - & - & - & - \\
\hline Stuart \& Tax '04 & - & - & - & - & - & - & - & - & - & - & - & - & - \\
\hline Edvardsson et al. '05 & $\mathrm{x}$ & $\mathrm{x}$ & $\mathrm{x}$ & - & - & - & - & $\mathrm{x}$ & $\mathrm{x}$ & - & - & $\mathrm{x}$ & $\mathrm{x}$ \\
\hline Berry et al. '06 & - & $\mathrm{x}$ & $\mathrm{x}$ & - & - & - & - & - & $\mathrm{x}$ & - & - & - & - \\
\hline Schembri ‘06 & $\mathrm{x}$ & - & - & - & - & - & - & $\mathrm{x}$ & - & - & - & - & - \\
\hline Frow and Payne '07 & $\mathrm{x}$ & $\mathrm{x}$ & $\mathrm{x}$ & - & - & - & - & - & - & - & - & - & - \\
\hline Gentile et al. '07 & $\mathrm{x}$ & $\mathrm{x}$ & $\mathrm{x}$ & $\mathrm{x}$ & $\mathrm{x}$ & $\mathrm{x}$ & - & - & - & - & - & - & - \\
\hline Knutson et al. '07 & $\mathrm{x}$ & - & - & - & - & - & - & - & - & - & - & - & - \\
\hline Oh et al. '07 & - & $\mathrm{x}$ & $\mathrm{x}$ & $\mathrm{x}$ & - & - & - & - & - & - & - & - & - \\
\hline Schouten et al. '07 & - & $\mathrm{x}$ & - & - & - & - & $\mathrm{x}$ & - & - & - & - & $\mathrm{x}$ & $\mathrm{x}$ \\
\hline
\end{tabular}




\begin{tabular}{|c|c|c|c|c|c|c|c|c|c|c|c|c|c|}
\hline \multirow{2}{*}{$\begin{array}{l}\text { PAPER } \\
\text { Author - Year }\end{array}$} & \multirow[b]{2}{*}{$\begin{array}{c}\text { PARTICIPATION } \\
\text { LEVEL }\end{array}$} & \multicolumn{5}{|c|}{ DIMENSIONALITY } & \multicolumn{2}{|c|}{ TEMPORALITY } & \multicolumn{3}{|c|}{ VALENCE } & \multicolumn{2}{|c|}{ ORDINARINESS } \\
\hline & & 胥 & 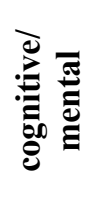 & 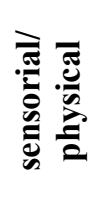 & 䎡 & 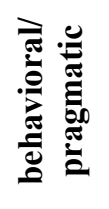 & 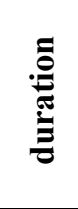 & 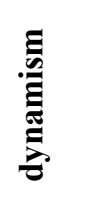 & 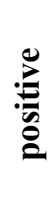 & 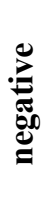 & 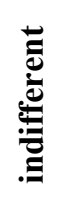 & 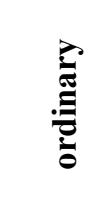 & 莺 \\
\hline Meyer and Schwager '07 & - & - & - & - & - & - & - & - & - & - & - & - & - \\
\hline Patricio et al. '08 & $\mathrm{x}$ & - & - & - & - & - & - & - & $\mathrm{x}$ & - & - & - & - \\
\hline Payne et al. '08 & $\mathrm{x}$ & $\mathrm{x}$ & $\mathrm{x}$ & - & - & $\mathrm{x}$ & - & $\mathrm{x}$ & - & - & - & - & - \\
\hline Sandström et al. '08 & $\mathrm{x}$ & $\mathrm{x}$ & $\mathrm{x}$ & $\mathrm{x}$ & - & $\mathrm{x}$ & - & - & $\mathrm{x}$ & - & - & $\mathrm{x}$ & $\mathrm{x}$ \\
\hline Voss et al. '08 & $\mathrm{x}$ & $\mathrm{x}$ & $\mathrm{x}$ & $\mathrm{x}$ & - & - & - & - & - & - & - & $\mathrm{x}$ & $\mathrm{x}$ \\
\hline Brakus et al. '09 & - & $\mathrm{x}$ & $\mathrm{x}$ & $\mathrm{x}$ & $\mathrm{x}$ & - & $\mathrm{x}$ & $\mathrm{x}$ & $\mathrm{x}$ & $\mathrm{x}$ & - & - & - \\
\hline Grewal et al. '09 & $\mathrm{x}$ & $\mathrm{x}$ & $\mathrm{x}$ & $\mathrm{x}$ & $\mathrm{x}$ & - & - & - & - & - & - & - & - \\
\hline Payne et al. '09 & $\mathrm{x}$ & $\mathrm{x}$ & $\mathrm{x}$ & - & - & $\mathrm{x}$ & $\mathrm{x}$ & - & - & - & - & $\mathrm{x}$ & $\mathrm{x}$ \\
\hline Puccinelli et al. '09 & - & $\mathrm{x}$ & - & $\mathrm{x}$ & - & - & - & - & - & - & - & - & - \\
\hline Tynan \& McKechnie '09 & $\mathrm{x}$ & $\mathrm{x}$ & $\mathrm{x}$ & $\mathrm{x}$ & $\mathrm{x}$ & - & $\mathrm{x}$ & - & - & - & - & - & - \\
\hline Verhoef et al. '09 & - & $\mathrm{x}$ & $\mathrm{x}$ & $\mathrm{x}$ & $\mathrm{x}$ & - & - & $\mathrm{x}$ & $\mathrm{x}$ & - & - & - & - \\
\hline Zehrer et al. '09 & - & $\mathrm{x}$ & $\mathrm{x}$ & - & - & - & - & - & - & - & - & - & - \\
\hline Baron \& Harris ' 10 & - & - & - & - & - & - & - & - & - & - & - & - & - \\
\hline Edvardsson et al. '10 & $\mathrm{x}$ & $\mathrm{x}$ & $\mathrm{x}$ & $\mathrm{x}$ & - & - & - & - & - & - & - & - & - \\
\hline Ferguson et al. '10 & $\mathrm{x}$ & $\mathrm{x}$ & $\mathrm{x}$ & - & - & - & - & - & - & - & - & - & - \\
\hline Keinan \& Kevitz '10 & $\mathrm{x}$ & $\mathrm{x}$ & - & - & - & - & - & - & $\mathrm{x}$ & $\mathrm{x}$ & - & $\mathrm{x}$ & $\mathrm{x}$ \\
\hline Palmer '10 & - & $\mathrm{x}$ & $\mathrm{x}$ & $\mathrm{x}$ & - & - & - & $\mathrm{x}$ & - & - & - & - & - \\
\hline Rinallo et al. ' 10 & - & $\mathrm{x}$ & $\mathrm{x}$ & $\mathrm{x}$ & $\mathrm{x}$ & - & - & - & - & - & - & - & - \\
\hline Schmitt ' 10 & - & $\mathrm{x}$ & $\mathrm{x}$ & $\mathrm{x}$ & - & $\mathrm{x}$ & - & $\mathrm{x}$ & $\mathrm{x}$ & $\mathrm{x}$ & - & $\mathrm{x}$ & $\mathrm{x}$ \\
\hline Walter et al. ' 10 & $\mathrm{x}$ & $\mathrm{x}$ & $\mathrm{x}$ & - & - & $\mathrm{x}$ & $\mathrm{x}$ & $\mathrm{x}$ & - & - & - & - & - \\
\hline Zomerdijk \& Voss ' 10 & - & $\mathrm{x}$ & $\mathrm{x}$ & $\mathrm{x}$ & - & - & - & $\mathrm{x}$ & $\mathrm{x}$ & $\mathrm{x}$ & $\mathrm{x}$ & - & - \\
\hline Helkulla '11 & - & - & - & - & - & - & - & - & - & - & - & - & - \\
\hline Iglesias et al. 11 & - & $\mathrm{x}$ & $\mathrm{x}$ & $\mathrm{x}$ & - & $\mathrm{x}$ & - & - & - & - & - & - & - \\
\hline Johnston \& Kong '11 & - & $\mathrm{x}$ & - & - & - & - & - & - & $\mathrm{x}$ & $\mathrm{x}$ & $\mathrm{x}$ & - & - \\
\hline Kim et al. ' 11 & - & - & - & - & - & - & - & - & - & - & - & - & - \\
\hline Lemke et al. '11 & - & - & - & - & - & - & - & - & $\mathrm{x}$ & $\mathrm{x}$ & - & $\mathrm{x}$ & $\mathrm{x}$ \\
\hline Nambisan \& Watt '11 & $\mathrm{x}$ & $\mathrm{x}$ & $\mathrm{x}$ & - & - & - & - & - & - & - & - & - & - \\
\hline Patricio et al. ‘11 & $\mathrm{x}$ & - & - & - & - & - & - & - & - & - & - & - & - \\
\hline
\end{tabular}




\begin{tabular}{|c|c|c|c|c|c|c|c|c|c|c|c|c|c|}
\hline \multirow{2}{*}{$\begin{array}{l}\text { PAPER } \\
\text { Author - Year }\end{array}$} & \multirow[b]{2}{*}{$\begin{array}{l}\text { PARTICIPATION } \\
\text { LEVEL }\end{array}$} & \multicolumn{5}{|c|}{ DIMENSIONALITY } & \multicolumn{2}{|c|}{ TEMPORALITY } & \multicolumn{3}{|c|}{ VALENCE } & \multicolumn{2}{|c|}{ ORDINARINESS } \\
\hline & & 言离 & 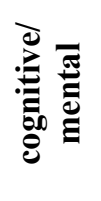 & 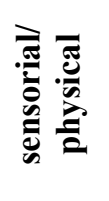 & 产 & 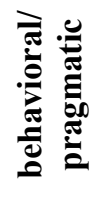 & 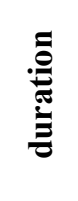 & 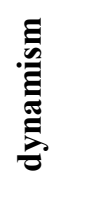 & 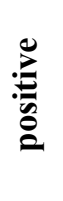 & 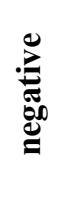 & 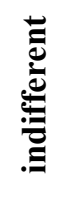 & : & 恶 \\
\hline Rose et al. '11 & - & $\mathrm{x}$ & $\mathrm{x}$ & - & - & - & - & - & - & - & - & - & - \\
\hline Tumbat '11 & - & $\mathrm{x}$ & - & - & - & - & - & - & - & - & - & - & - \\
\hline Tumbat and Belk '11 & $\mathrm{x}$ & $\mathrm{x}$ & - & - & $\mathrm{x}$ & - & - & - & - & - & - & $\mathrm{x}$ & $\mathrm{x}$ \\
\hline Brocato et al. '12 & - & - & - & - & - & - & - & - & - & - & - & - & - \\
\hline Helkulla et al. ' $12 \mathrm{a}$ & - & $\mathrm{x}$ & $\mathrm{x}$ & - & - & - & - & - & - & - & - & $\mathrm{x}$ & $\mathrm{x}$ \\
\hline Helkulla et al. ‘ $12 b$ & - & - & - & - & - & - & - & $\mathrm{x}$ & - & - & - & - & - \\
\hline Klaus \& Maklan '12 & - & $\mathrm{x}$ & $\mathrm{x}$ & - & - & - & - & - & - & - & - & - & - \\
\hline Otnes et al. ' 12 & - & - & - & - & - & - & - & - & - & - & - & - & - \\
\hline Rose et al. ' 12 & $\mathrm{x}$ & $\mathrm{x}$ & $\mathrm{x}$ & - & $\mathrm{x}$ & - & - & - & - & - & - & - & - \\
\hline Teixeira et al. '12 & - & - & - & - & - & - & - & - & - & - & - & - & - \\
\hline Hellén \& Gummerus ‘13 & - & $\mathrm{x}$ & $\mathrm{x}$ & $\mathrm{x}$ & $\mathrm{x}$ & - & $\mathrm{x}$ & - & - & - & - & $\mathrm{x}$ & $\mathrm{x}$ \\
\hline Jüttner et al. '13 & $\mathrm{x}$ & $\mathrm{x}$ & $\mathrm{x}$ & - & - & - & - & - & - & - & - & - & - \\
\hline Klaus ‘13 & - & $\mathrm{x}$ & $\mathrm{x}$ & $\mathrm{x}$ & - & - & - & - & - & - & - & - & - \\
\hline Manthiou et al. '13 & $\mathrm{x}$ & $\mathrm{x}$ & $\mathrm{x}$ & $\mathrm{x}$ & - & $\mathrm{x}$ & - & - & - & - & - & $\mathrm{x}$ & $\mathrm{x}$ \\
\hline Martin et al. '13 & - & $\mathrm{x}$ & $\mathrm{x}$ & - & - & - & - & - & - & - & - & - & - \\
\hline Morgan-Thomas and Veloutsou '13 & - & $\mathrm{x}$ & $\mathrm{x}$ & - & - & - & - & - & - & - & - & - & - \\
\hline Nysveen et al. '13 & - & $\mathrm{x}$ & $\mathrm{x}$ & $\mathrm{x}$ & $\mathrm{x}$ & $\mathrm{x}$ & - & - & - & - & - & - & - \\
\hline Rawson et al. '13 & - & - & - & - & - & - & - & - & - & - & - & - & - \\
\hline Tax et al. ' 13 & $\mathrm{x}$ & - & - & - & - & - & - & - & - & - & - & - & - \\
\hline Åkesson et al. '14 & - & - & - & - & - & - & - & - & $\mathrm{x}$ & $\mathrm{x}$ & - & - & - \\
\hline Bolton et al. '14 & $\mathrm{x}$ & $\mathrm{x}$ & $\mathrm{x}$ & $\mathrm{x}$ & $\mathrm{x}$ & $\mathrm{x}$ & - & - & $\mathrm{x}$ & $\mathrm{x}$ & - & - & - \\
\hline Bhattacharjee \& Mogilner '14 & - & - & - & - & - & - & - & - & - & - & - & $\mathrm{x}$ & $\mathrm{x}$ \\
\hline Kumar et al. '14 & - & - & $\mathrm{x}$ & - & - & - & - & - & - & - & - & - & - \\
\hline Akaka et al. ' 15 & $\mathrm{x}$ & - & - & - & - & - & $\mathrm{x}$ & - & $\mathrm{x}$ & $\mathrm{x}$ & - & - & - \\
\hline Carù \& Cova '15 & $\mathrm{x}$ & $\mathrm{x}$ & - & - & - & - & - & - & $\mathrm{x}$ & $\mathrm{x}$ & - & - & - \\
\hline Chandler \& Lusch ‘15 & $\mathrm{x}$ & $\mathrm{x}$ & $\mathrm{x}$ & - & - & $\mathrm{x}$ & $\mathrm{x}$ & $\mathrm{x}$ & - & - & - & - & - \\
\hline De Keyser et al. '15 & $\mathrm{x}$ & $\mathrm{x}$ & $\mathrm{x}$ & $\mathrm{x}$ & $\mathrm{x}$ & $\mathrm{x}$ & - & - & $\mathrm{x}$ & $\mathrm{x}$ & - & $\mathrm{x}$ & $\mathrm{x}$ \\
\hline Ding and Tseng ' 15 & - & $\mathrm{x}$ & $\mathrm{x}$ & $\mathrm{x}$ & $\mathrm{x}$ & $\mathrm{x}$ & - & - & - & - & - & - & - \\
\hline
\end{tabular}




\begin{tabular}{|c|c|c|c|c|c|c|c|c|c|c|c|c|c|}
\hline \multirow{2}{*}{$\begin{array}{l}\text { PAPER } \\
\text { Author - Year }\end{array}$} & \multirow[b]{2}{*}{$\begin{array}{c}\text { PARTICIPATION } \\
\text { LEVEL }\end{array}$} & \multicolumn{5}{|c|}{ DIMENSIONALITY } & \multicolumn{2}{|c|}{ TEMPORALITY } & \multicolumn{3}{|c|}{ VALENCE } & \multicolumn{2}{|c|}{ ORDINARINESS } \\
\hline & & 屁 & 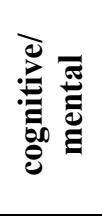 & 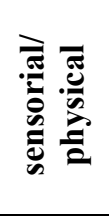 & 产 & 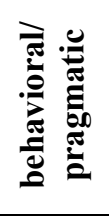 & : & 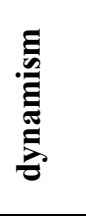 & 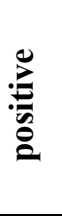 & 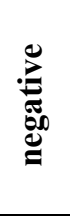 & 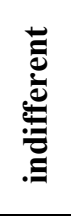 & : & 苛 \\
\hline Dube \& Helkkula '15 & $\mathrm{x}$ & - & - & - & - & - & - & $\mathrm{x}$ & - & - & - & - & - \\
\hline Jaakkola et al. 15 & $\mathrm{x}$ & - & - & - & - & - & - & - & - & - & - & - & - \\
\hline Lanier \& Rader ' 15 & $\mathrm{x}$ & - & - & - & - & - & - & - & - & - & - & $\mathrm{x}$ & $\mathrm{x}$ \\
\hline McColl-Kennedy et al. ' 15 & $\mathrm{x}$ & $\mathrm{x}$ & $\mathrm{x}$ & $\mathrm{x}$ & $\mathrm{x}$ & - & - & $\mathrm{x}$ & - & - & - & $\mathrm{x}$ & $\mathrm{x}$ \\
\hline Ponsignon et al. ' 15 & $\mathrm{x}$ & $\mathrm{x}$ & $\mathrm{x}$ & - & - & - & $\mathrm{x}$ & - & - & - & - & - & - \\
\hline Schmitt et al. ' 15 & - & $\mathrm{x}$ & $\mathrm{x}$ & $\mathrm{x}$ & $\mathrm{x}$ & - & $\mathrm{x}$ & - & - & - & - & $\mathrm{x}$ & $\mathrm{x}$ \\
\hline Verleye ' 15 & $\mathrm{x}$ & $\mathrm{x}$ & $\mathrm{x}$ & - & $\mathrm{x}$ & - & - & - & - & - & - & - & - \\
\hline Woermann \& Rokka '15 & $\mathrm{x}$ & $\mathrm{x}$ & $\mathrm{x}$ & - & - & - & $\mathrm{x}$ & $\mathrm{x}$ & $\mathrm{x}$ & $\mathrm{x}$ & - & - & - \\
\hline Yakhlef'15 & $\mathrm{x}$ & $\mathrm{x}$ & $\mathrm{x}$ & $\mathrm{x}$ & $\mathrm{x}$ & - & - & - & - & - & - & - & - \\
\hline Albrecht et al. '16 & - & $\mathrm{x}$ & - & - & - & - & - & - & $\mathrm{x}$ & $\mathrm{x}$ & - & - & - \\
\hline Anderson \& Smith '16 & - & $\mathrm{x}$ & $\mathrm{x}$ & - & - & - & - & $\mathrm{x}$ & - & - & - & - & - \\
\hline Beltagui et al. ' 16 & $\mathrm{x}$ & $\mathrm{x}$ & - & - & - & - & - & - & - & - & - & - & - \\
\hline Ebrahim et al. ' 16 & - & $\mathrm{x}$ & $\mathrm{x}$ & $\mathrm{x}$ & - & $\mathrm{x}$ & - & - & - & - & - & - & - \\
\hline Fernandes and Cruz '16 & - & $\mathrm{x}$ & $\mathrm{x}$ & - & - & - & - & - & - & - & - & $\mathrm{x}$ & $\mathrm{x}$ \\
\hline Khan and Rahman '16 & - & $\mathrm{x}$ & $\mathrm{x}$ & - & - & - & - & - & - & - & - & - & - \\
\hline Lemon \& Verhoef ‘'16 & $\mathrm{x}$ & $\mathrm{x}$ & $\mathrm{x}$ & $\mathrm{x}$ & $\mathrm{x}$ & $\mathrm{x}$ & - & $\mathrm{x}$ & - & - & - & - & - \\
\hline Lipkin '16 & $\mathrm{x}$ & $\mathrm{x}$ & $\mathrm{x}$ & - & - & - & - & $\mathrm{x}$ & - & - & - & - & - \\
\hline Srivasrava and Kaul ' 16 & - & $\mathrm{x}$ & $\mathrm{x}$ & $\mathrm{x}$ & - & $\mathrm{x}$ & - & - & - & - & - & - & - \\
\hline Stein and Ramaseshan '16 & - & - & - & - & - & - & - & - & - & - & - & - & - \\
\hline Tafesse ' 16 & - & $\mathrm{x}$ & $\mathrm{x}$ & $\mathrm{x}$ & $\mathrm{x}$ & $\mathrm{x}$ & - & - & - & - & - & - & - \\
\hline Trudeau and Shobeiri ' 16 & - & $\mathrm{x}$ & $\mathrm{x}$ & $\mathrm{x}$ & - & $\mathrm{x}$ & - & - & - & - & - & - & - \\
\hline Bustamante \& Rubio ‘17 & $\mathrm{x}$ & $\mathrm{x}$ & $\mathrm{x}$ & $\mathrm{x}$ & $\mathrm{x}$ & - & - & - & - & - & - & - & - \\
\hline Homburg et al. '17 & - & $\mathrm{x}$ & $\mathrm{x}$ & $\mathrm{x}$ & $\mathrm{x}$ & $\mathrm{x}$ & - & - & - & - & - & - & - \\
\hline Jain et al. '17 & - & $\mathrm{x}$ & $\mathrm{x}$ & $\mathrm{x}$ & - & $\mathrm{x}$ & - & - & - & - & - & - & - \\
\hline Keiningham et al. ' 17 & - & $\mathrm{x}$ & $\mathrm{x}$ & $\mathrm{x}$ & $\mathrm{x}$ & $\mathrm{x}$ & - & - & - & - & - & - & - \\
\hline Mohd-Ramly and Omar '17 & - & $\mathrm{x}$ & $\mathrm{x}$ & $\mathrm{x}$ & - & $\mathrm{x}$ & - & - & - & - & - & - & - \\
\hline Ponsignon et al. '17 & $\mathrm{x}$ & $\mathrm{x}$ & $\mathrm{x}$ & - & - & - & $\mathrm{x}$ & - & - & - & - & - & - \\
\hline Scott et al. ' 17 & $\mathrm{x}$ & $\mathrm{x}$ & - & - & - & $\mathrm{x}$ & $\mathrm{x}$ & - & $\mathrm{x}$ & $\mathrm{x}$ & - & - & $\mathrm{x}$ \\
\hline
\end{tabular}




\begin{tabular}{|c|c|c|c|c|c|c|c|c|c|c|c|c|c|}
\hline \multirow{2}{*}{\begin{tabular}{|l} 
PAPER \\
Author - Year
\end{tabular}} & \multirow[b]{2}{*}{$\begin{array}{c}\text { PARTICIPATION } \\
\text { LEVEL }\end{array}$} & \multicolumn{5}{|c|}{ DIMENSIONALITY } & \multicolumn{2}{|c|}{ TEMPORALITY } & \multicolumn{3}{|c|}{ VALENCE } & \multicolumn{2}{|c|}{ ORDINARINESS } \\
\hline & & 萞 & 䊿 & 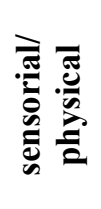 & 焉 & 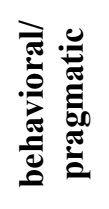 & 苞 & 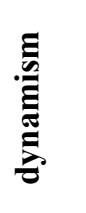 & $\begin{array}{l}\stackrel{0}{0} \\
\vdots \\
0\end{array}$ & : & 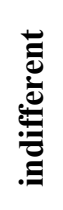 & 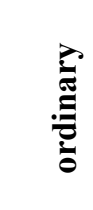 & : \\
\hline Voorhees et al. '17 & - & $\mathrm{x}$ & $\mathrm{x}$ & $\mathrm{x}$ & $\mathrm{x}$ & $\mathrm{x}$ & $\mathrm{x}$ & $\mathrm{x}$ & - & - & - & - & - \\
\hline Zolkiewski et al. ' 17 & $\mathrm{x}$ & $\mathrm{x}$ & $\mathrm{x}$ & $\mathrm{x}$ & $\mathrm{x}$ & $\mathrm{x}$ & - & - & - & - & - & - & - \\
\hline Bolton et al. ' 18 & $\mathrm{x}$ & $\mathrm{x}$ & $\mathrm{x}$ & $\mathrm{x}$ & $\mathrm{x}$ & - & - & - & $\mathrm{x}$ & $\mathrm{x}$ & - & - & - \\
\hline Collier et al. '18 & - & $\mathrm{x}$ & $\mathrm{x}$ & - & - & - & - & - & - & - & - & - & $\mathrm{x}$ \\
\hline Dwivedi et al. '18 & - & $\mathrm{x}$ & $\mathrm{x}$ & $\mathrm{x}$ & - & $\mathrm{x}$ & - & - & - & - & - & - & - \\
\hline Hoffman \& Novak ' 18 & $\mathrm{x}$ & $\mathrm{x}$ & $\mathrm{x}$ & $\mathrm{x}$ & $\mathrm{x}$ & $\mathrm{x}$ & $\mathrm{x}$ & $\mathrm{x}$ & - & - & - & - & - \\
\hline Kranzbühler et al. ' 18 & $\mathrm{x}$ & $\mathrm{x}$ & $\mathrm{x}$ & $\mathrm{x}$ & $\mathrm{x}$ & - & $\mathrm{x}$ & $\mathrm{x}$ & $\mathrm{x}$ & $\mathrm{x}$ & - & $\mathrm{x}$ & $\mathrm{x}$ \\
\hline Kumar et al. ' 18 & - & $\mathrm{x}$ & $\mathrm{x}$ & $\mathrm{x}$ & - & $\mathrm{x}$ & - & - & - & - & - & - & - \\
\hline McLean et al. '18 & - & $\mathrm{x}$ & $\mathrm{x}$ & - & - & - & - & - & $\mathrm{x}$ & $\mathrm{x}$ & - & - & - \\
\hline Roy ‘18 & - & $\mathrm{x}$ & $\mathrm{x}$ & - & - & - & - & - & - & - & - & - & - \\
\hline Roy et al. ' 18 & - & $\mathrm{x}$ & $\mathrm{x}$ & - & - & - & - & - & - & - & - & - & - \\
\hline Still et al. ' 18 & - & - & - & - & - & - & - & - & - & - & - & - & - \\
\hline Sultan '18 & - & $\mathrm{x}$ & $\mathrm{x}$ & - & - & $\mathrm{x}$ & - & - & - & - & - & - & - \\
\hline Trischler et al. '18 & $\mathrm{x}$ & - & - & - & - & - & - & - & $\mathrm{x}$ & $\mathrm{x}$ & - & - & - \\
\hline Wiedmann et al. '18 & - & $\mathrm{x}$ & $\mathrm{x}$ & $\mathrm{x}$ & - & $\mathrm{x}$ & - & - & - & - & - & - & - \\
\hline Al-Wugayan '19 & - & $\mathrm{x}$ & $\mathrm{x}$ & - & - & - & - & - & - & - & - & - & - \\
\hline Bleier et al. '19 & - & $\mathrm{x}$ & $\mathrm{x}$ & $\mathrm{x}$ & $\mathrm{x}$ & - & - & - & - & - & - & - & - \\
\hline Jaziri ‘19 & $\mathrm{x}$ & $\mathrm{x}$ & $\mathrm{x}$ & $\mathrm{x}$ & $\mathrm{x}$ & $\mathrm{x}$ & - & - & - & - & - & - & - \\
\hline Kabadayi et al. '19 & $\mathrm{x}$ & $\mathrm{x}$ & $\mathrm{x}$ & - & - & $\mathrm{x}$ & - & - & - & - & - & - & - \\
\hline Komulainen and Saraniemi '19 & $\mathrm{x}$ & $\mathrm{x}$ & $\mathrm{x}$ & - & $\mathrm{x}$ & $\mathrm{x}$ & - & - & - & - & - & - & - \\
\hline Kranzbühler et al. '19 & - & - & - & - & - & - & - & - & $\mathrm{x}$ & $\mathrm{x}$ & $\mathrm{x}$ & - & - \\
\hline Kuehnl et al. '19 & - & $\mathrm{x}$ & $\mathrm{x}$ & $\mathrm{x}$ & $\mathrm{x}$ & $\mathrm{x}$ & - & - & - & - & - & - & - \\
\hline Kumar et al. '19 & $\mathrm{x}$ & - & - & - & - & - & - & - & $\mathrm{x}$ & $\mathrm{x}$ & - & - & - \\
\hline Kuuru and Närvänen '19 & $\mathrm{x}$ & $\mathrm{x}$ & $\mathrm{x}$ & $\mathrm{x}$ & - & $\mathrm{x}$ & - & - & - & - & - & - & - \\
\hline Mahr et al. '19 & - & $\mathrm{x}$ & $\mathrm{x}$ & $\mathrm{x}$ & $\mathrm{x}$ & $\mathrm{x}$ & - & - & $\mathrm{x}$ & $\mathrm{x}$ & - & - & - \\
\hline McColl-Kennedy et al. '19 & $\mathrm{x}$ & $\mathrm{x}$ & $\mathrm{x}$ & - & - & - & - & - & - & - & - & - & - \\
\hline Roy et al. '19 & $\mathrm{x}$ & $\mathrm{x}$ & $\mathrm{x}$ & - & $\mathrm{x}$ & - & - & - & - & - & - & - & - \\
\hline Schallehn et al. '19 & $\mathrm{x}$ & - & - & - & - & - & - & - & - & - & - & - & - \\
\hline
\end{tabular}




\begin{tabular}{|c|c|c|c|c|c|c|c|c|c|c|c|c|c|}
\hline \multirow{2}{*}{$\begin{array}{l}\text { PAPER } \\
\text { Author - Year }\end{array}$} & \multirow[b]{2}{*}{$\begin{array}{c}\text { PARTICIPATION } \\
\text { LEVEL }\end{array}$} & \multicolumn{5}{|c|}{ DIMENSIONALITY } & \multicolumn{2}{|c|}{ TEMPORALITY } & \multicolumn{3}{|c|}{ VALENCE } & \multicolumn{2}{|c|}{ ORDINARINESS } \\
\hline & & 产 & 离 & 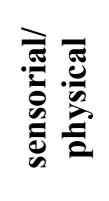 & 焉 & 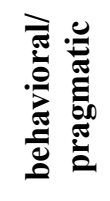 & & 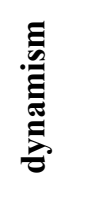 & 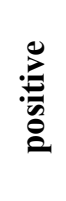 & 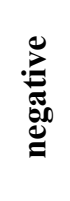 & & 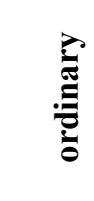 & 离 \\
\hline Skandalis et al. '19 & - & - & - & - & - & - & - & - & - & - & - & $\mathrm{x}$ & $\mathrm{x}$ \\
\hline Becker and Jaakkola '20 & $\mathrm{x}$ & $\mathrm{x}$ & $\mathrm{x}$ & $\mathrm{x}$ & $\mathrm{x}$ & $\mathrm{x}$ & - & $\mathrm{x}$ & $\mathrm{x}$ & $\mathrm{x}$ & - & $\mathrm{x}$ & $\mathrm{x}$ \\
\hline Flacandji \& Krey '20 & - & $\mathrm{x}$ & $\mathrm{x}$ & $\mathrm{x}$ & $\mathrm{x}$ & $\mathrm{x}$ & $\mathrm{x}$ & - & $\mathrm{x}$ & $\mathrm{x}$ & - & - & - \\
\hline Gao et al. '20 & - & $\mathrm{x}$ & $\mathrm{x}$ & - & $\mathrm{x}$ & - & - & - & - & - & - & - & - \\
\hline Keiningham et al. '20 & - & $\mathrm{x}$ & $\mathrm{x}$ & $\mathrm{x}$ & $\mathrm{x}$ & $\mathrm{x}$ & $\mathrm{x}$ & - & - & - & - & - & $\mathrm{x}$ \\
\hline
\end{tabular}

